\title{
Environmental Geophysics at J-Field, Aberdeen Proving Ground, Maryland
}

Energy Systems Division Argonne National Laboratory

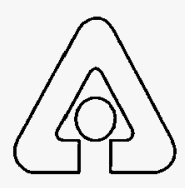

Operated by The University of Chicago, under Contract W-31-109-Eng-38, for the

United States Department of Energy 


\section{Argonne National Laboratory}

Argonne National Laboratory, with facilities in the states of Illinois and Idaho, is owned by the United States Government, and operated by the University of Chicago under the provisions of a contract with the Department of Energy.

This technical memo is a product of Argonne's Energy Systems (ES)

Division. For information on the division's scientific and engineering activities, contact:

Director, Energy Systems Division

Argonne National Laboratory

Argonne, lllinois 60439-4815

Telephone (708) 252-3724

Presented in this technical memo are preliminary results of ongoing work or work that is more limited in scope and depth than that described in formal reports issued by the ES Division.

\section{Disclaimer}

This report was prepared as an account of work sponsored by an agency of the United States Government. Neither the United States Government nor any agency thereof, nor any of their employees, makes any warranty, express or implied, or assumes any legal liability or responsibility for the accuracy, completeness, or usefulness of any information, apparatus, product, or process disclosed, or represents that its use would not infringe privately owned rights. Reference herein to any specific commercial product, process, or service by trade name, trademark, manufacturer, or otherwise, does not necessarily constitute or imply its endorsement, recommendation, or favoring by the United States Government or any agency thereof. The views and opinions of authors expressed herein do not necessarily state or reflect those of the United States Government or any agency thereof.

Reproduced directly from the best available copy.

Available to DOE and DOE contractors from the Office of Scientific and Technical Information, P.O. Box 62, Oak Ridge, TN 37831; prices available from (615) 576-8401.

Available to the public from the National Technical Information Service, U.S. Department of Commerce, 5285 Port Royal Road, Springfield, VA 22161. 


\section{DISCLAIMER}

Portions of this document may be illegible in electronic image products. Images are produced from the best available original document. 


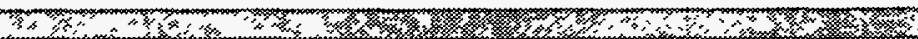

\section{Environmental Geophysics at J-Field, Aberdeen Proving Ground, Maryland}

by C.R. Daudt, L.D. McGinnis, S.F. Miller, and M.D. Thompson

Reclamation Engineering and Geosciences Section, Energy Systems Division, Argonne National Laboratory, 9700 South Cass Avenue, Argonne, Illinois 60439

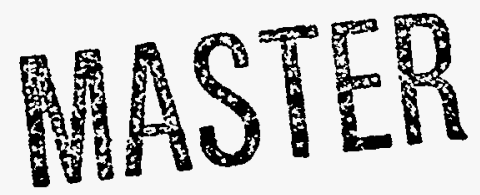

November 1994

Work sponsored by United States Army, Aberdeen Proving Ground, Maryland DISIMIBUIIUN UF THIS DOCUIVIENT IS UNLIMITED 
89

This report is printed on recycled paper. 


\section{Preface}

This report provides administrative and technical staff responsible for environmental planning and remediation at J-Field with the final results and conclusions drawn from geophysical studies that commenced in mid-July 1993. The Geophysics Work Plan 1993 emphasized the need for an increased understanding of the hydrogeologic framework beneath specific locations at $\mathrm{J}$-Field. Areas that needed study included those with a history of significant contamination from military testing; burning; and disposal of explosives, chemical munitions, and other environmentally adverse substances. Several technologies were employed to determine the presence or former presence of contaminants, including surface spills, buried tanks, pipes, and trenches. 


\section{Contents}

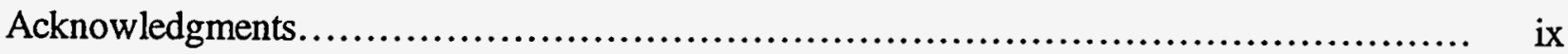

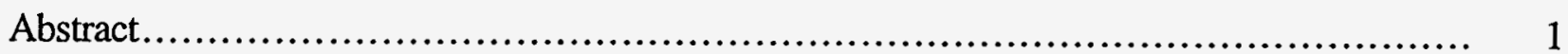

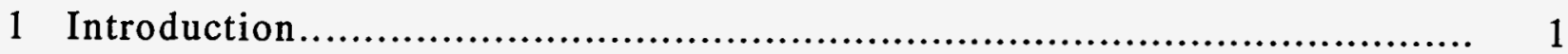

2 Physiographic Setting and Hydrogeology ....................................... 6

3 Geophysical Studies .............................................................. 12

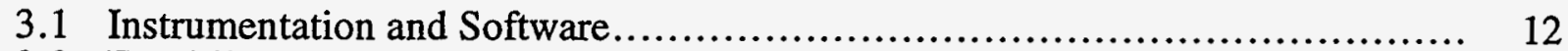

3.2 Establishment of Survey Areas............................................... 12

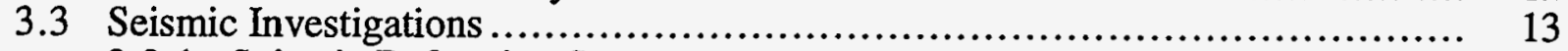

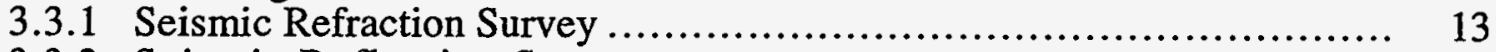

3.3.2 Seismic Reflection Survey.................................................. 22

3.4 Electrical Resistivity Depth Soundings ...................................... 34

3.5 Electrical Conductivity ....................................................... 39

3.5.1 Toxic Burning Pits Site .................................................... 40

3.5.2 White Phosphorous Burning Pits Site ................................... 42

3.5.3 West Side of Prototype Building Site ................................ 44

3.5.4 South Beach Road Profile ........................................... 44

3.5.5 Profile Extending across Riot Control Pit Site ............................. 44

3.5.6 Profile along the South Shore of Gunpowder Neck Peninsula.......... 48

3.5.7 Riot Control Burning Pit Site............................................... 48

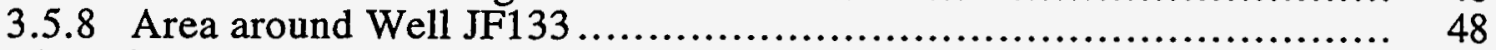

3.6 Magnetics ............................................................ 51

3.6.1 Toxic Burning Pits Site ...................................................... 51

3.6.2 White Phosphorous Burning Pits Site .............................. 53

3.6.3 West Side of Prototype Building Site............................... 54

3.6.4 Riot Control Burning Pit Site .................................. 55

3.7 Ground-Penetrating Radar Investigations .................................... 55

3.7.1 Toxic Burning Pits Site .......................................... 57

3.7.2 White Phosphorous Burning Pits Site .............................. 57

3.7.3 West Side of Prototype Building Site.................................. 57

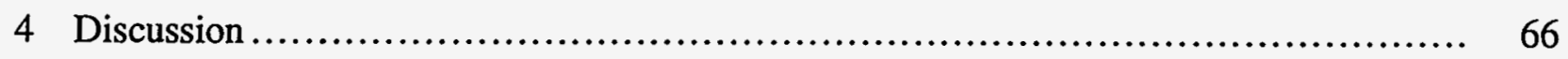

4.1 Geophysical Characterization of the Leaky Confining Unit ................... 66

4.2 Ground Disturbances at the Toxic Burning Pits Site ........................... 68

4.3 Ground Disturbances at the White Phosphorous Burning Pits Site............ 70

4.4 Ground Disturbances West of the Prototype Building Site .................... 70

4.5 Ground Disturbances at the Riot Control Burning Pit Site................... 70

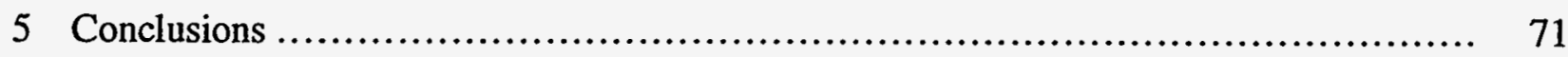

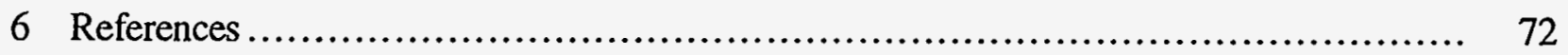




\section{Figures}

1 Location of J-Field in the Edgewood Area at APG.............................. 2

2 Locations of Areas of Concern and Principal Site Features at J-Field ............. 5

3 Location of Offshore Seismic Lines and Geologic Section D-D' through Pleistocene Sediments ...................................................... 7

4 Geologic Section D-D' through Pleistocene Sediments and Offshore Seismic Profiles.

5 Geologic Units and Generalized Directions of Groundwater Flow in the Upper Chesapeake Bay Area.............................................. 9

6 Locations of Existing Monitoring Wells at J-Field............................. 10

$7 \quad$ Locations of Geophysical Survey Areas......................................... 14

8 Detailed Map of TBP and PBW Geophysical Survey Sites ..................... 16

$9 \quad$ Detailed Map of WPP Geophysical Survey Site..................................... 17

10 Locations of ANL Seismic Refraction and Reflection Profiles ................... 19

11 First-Arrival Time vs. Distance Data from Seismic Refraction Line REFR-1 ...... 20

12 Seismic Velocity Model Interpreted along Refraction Line REFR-1 ............... 21

13 Detailed Locations of ANL Seismic Reflection Profiles at the

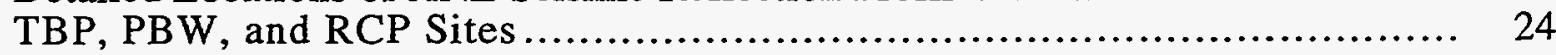

14 Detailed Locations of ANL Seismic Reflection Profiles at the WPP Site........... 25

15 Seismic Reflection Profile and Stick Diagram for Line 1-DP ..................... 27

16 Seismic Reflection Profile and Stick Diagram for Line $2 \ldots \ldots \ldots \ldots \ldots \ldots \ldots \ldots \ldots . . \ldots \ldots$

17 Seismic Reflection Profile and Stick Diagram for Line 3 ........................ 29

18 Seismic Reflection Profile and Stick Diagram for Line $4 \ldots \ldots \ldots \ldots \ldots \ldots \ldots \ldots \ldots . . \ldots \ldots$

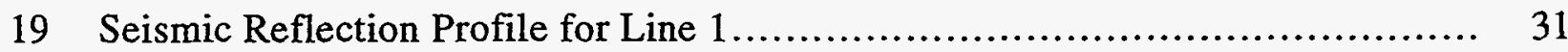

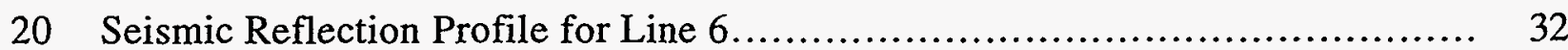

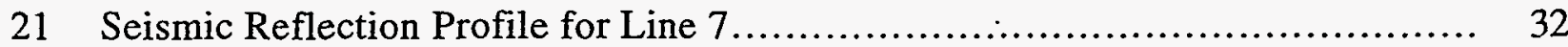

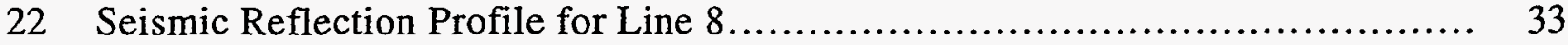

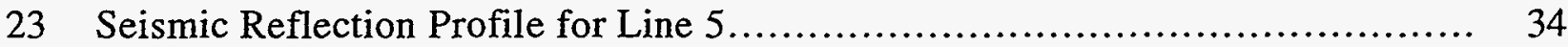

24 Locations of Electrical Resistivity Depth Soundings ............................ 35 


\section{Figures (Cont.)}

25 Apparent Resistivity Curves and Equivalent Resistivity-Depth Models for Profiles JF1-JF10

26 EM-31 Electromagnetic and Total-Field Magnetic Data for TBP Site.

27 EM-31 Electromagnetic and Total-Field Magnetic Data for the WPP Site

28 EM-31 Electromagnetic and Total-Field Magnetic Data for the PBW Site

29 EM-31 Electrical Conductivity Profile from Rickett Point Road South to Beach

30 EM-31 Electrical Conductivity Profile from Southwest End of Rickett

Point Road, across the RCP Site, to South Beach Road.

31 EM-31 Electrical Conductivity Profile from Southwest End of Rickett Point Road to South and East along Southern Shoreline of Gunpowder Neck Peninsula.

32 EM-31 Electrical Conductivity Color Map: RCP Site

33 EM-31 Electrical Conductivity Color Map: JF133 Area .

34 Total-Field Magnetic Color Map: TBP Site

35 Total-Field Magnetic Color Map: RCP Site

36 Locations of GPR Profiles: TBP Site.

37 GPR Profiles 13 and 28: TBP Site

38 GPR Profile 9: TBP Site

39 Location of GPR Profiles WPP Site

40 Location of GPR Profiles PBW Site

41 Color Maps of Unit B Interpreted from Seismic Reflection Data

42 Significant Features of the TBP Site as Interpreted from a 1965 Aerial Photograph.

\section{Tables}

1 Major Milestones for the J-Field Geophysics Program

2 Monitoring Well Depths at J-Field..

3 Grid Specifications for Geophysical Survey Areas. 


\section{Tables (Cont.)}

4 Corner Coordinates for Geophysical Survey Areas .............................. 18

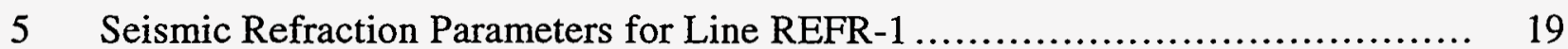

6 Seismic Reflection Parameters.................................................. 23

$7 \quad$ Electrical Resistivity Depth Sounding Parameters ................................ 35

8 Electrical Conductivity Parameters Using the EM-31 $\ldots \ldots \ldots \ldots \ldots \ldots \ldots \ldots \ldots \ldots \ldots$

9 Magnetic Survey Parameters............................................... 51

10 Ground-Penetrating Radar Profiles: TBP Site............................ 59

11 Ground-Penetrating Radar Profiles: WWP Site ............................... 63

12 Ground-Penetrating Radar Profiles: PBW Site............................. 65 


\section{Acknowledgments}

The work scope and its objectives were guided by members of the Environmental Assessment Division of Argonne National Laboratory and by staff at Aberdeen Proving Ground's Directorate of Safety, Health, and the Environment. The field-data acquisition team included Mike Thompson, Rob Pell, Lisa Sachnoff, Steve Miller, and Lyle McGinnis, all from Argonne National Laboratory, Reclamation Engineering and Geosciences Section, Energy Systems Division. The geophysical study conforms to the work plan submitted by Lou Martino (Argonne National Laboratory) to Steve Hirsh, (U.S. Environmental Protection Agency) on June 15, 1993. 


\title{
Environmental Geophysics at J-Field, Aberdeen Proving Ground, Maryland
}

by

C.R. Daudt, L.D. McGinnis, S.F. Miller, and M.D. Thompson

\begin{abstract}
Geophysical data collected at J-Field, Aberdeen Proving Ground, Maryland, were used in the characterization of the natural hydrogeologic framework of the J-Field area and in the identification of buried disturbances (trenches and other evidences of contamination). Seismic refraction and reflection data and electrical resistivity data have aided in the characterization of the leaky confining unit at the base of the surficial aquifer (designated Unit B of the Tertiary Talbot Formation). Excellent reflectors have been observed for both upper and lower surfaces of Unit B that correspond to stratigraphic units observed in boreholes and on gamma logs. Elevation maps of both surfaces and an isopach map of Unit B, created from reflection data at the toxic burning pits site, show a thickening of Unit B to the east. Abnormally low seismic compressional-wave velocities suggest that Unit B consists of gassy sediments whose gases are not being flushed by upward or downward moving groundwater. The presence of gases suggests that Unit B serves as an efficient aquitard that should not be penetrated by drilling or other activities. Electromagnetic, total-intensity magnetic, and ground-penetrating radar surveys have aided in delineating the limits of two buried trenches, the VX burning pit and the liquid smoke disposal pit, both located at the toxic burning pits site. The techniques have also aided in determining the extent of several other disturbed areas where soils and materials were pushed out of disposal pits during trenching activities. Surveys conducted from the Prototype Building west to the Gunpowder River did not reveal any buried trenches.
\end{abstract}

\section{Introduction}

A geophysics program was initiated at J-Field, Aberdeen Proving Ground (APG), in support of a remedial investigation and feasibility study conducted by Argonne National Laboratory (ANL). The remedial investigation and feasibility study is being conducted pursuant to the Comprehensive Environmental Response, Compensation, and Liability Act, as amended. J-Field is located at the southernmost tip of the Gunpowder Neck Peninsula within the Edgewood Area of APG in Harford County, Maryland. Figure 1 shows the location of J-Field. 


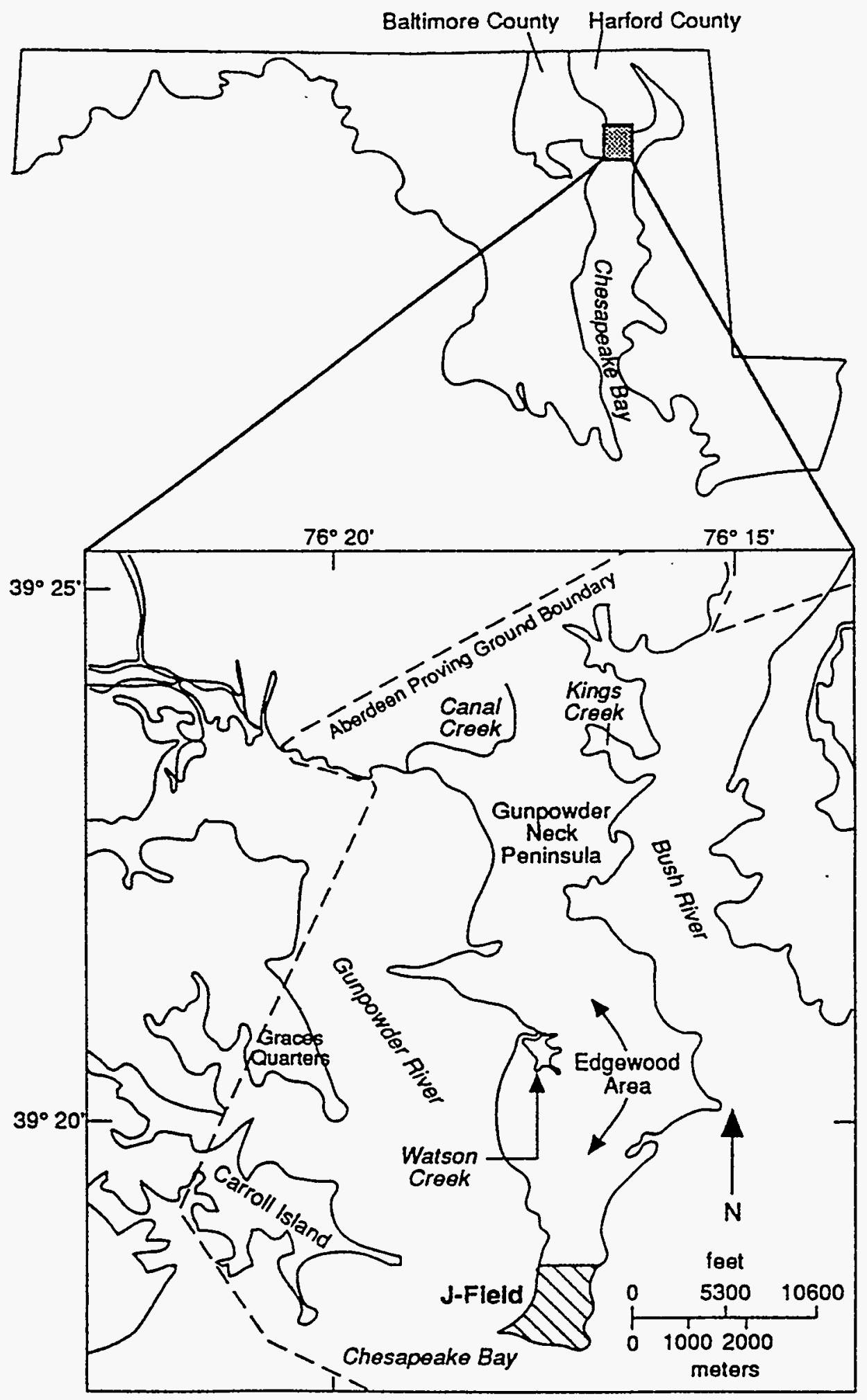

FIGURE 1 Location of J-Field in the Edgewood Area at APG (Source: Adapted from Hughes 1991) 
Objectives of the geophysical investigations (outlined in the Geophysics Work Plan 1993) were to:

1. Define the boundaries of known burial trenches and to locate and define undiscovered burial trenches.

2. Define the horizontal distribution of proposed conductive plumes or conductive debris identified during U.S. Geological Survey (USGS) reconnaissance electromagnetic (EM) surveys and to determine if the anomalies have changed over time.

3. Accurately map the configuration of the leaky confining unit at the base of the surficial aquifer to help identify possible pathways and accumulation points for deise, nonaqueous-phase liquids (DNAPLs).

The three-week field program, which commenced during the summer of 1993, included geophysics techniques as outlined in the June 1993 Geophysics Work Plan. A summary of the chronology of field activities is shown in Table 1. Techniques implemented include seismic refraction and reflection, magnetics, electromagnetics, electrical resistivity, and ground-penetrating radar (GPR). Geophysical surveys within J-Field include the area around the toxic burning pits (TBP); the area around the white phosphorus burning pits (WPP); west of the Prototype Building (PBW); the area around USGS well JF133; and east of the riot control burning pit (RCP). Profiles were conducted east of the TBP, along Rickett Point Road, and along the shoreline eastward from Rickett Point Road (Figure 2).

J-Field has been used for military activities since the early 1900s. Activities have included testing of high explosives and chemical munitions, open-pit burning or detonation of chemical agents and chemical wastes, open-air testing of lethal chemical agents, and disposal of small amounts of radioactively labeled chemicals. Military activities at J-Field escalated during World War II and remained active through the 1970s. J-Field has had only limited use since 1980, primarily for emergency destruction of unexploded ordinance and other explosive materials.

Assessments of environmental damage caused by contamination at $J$-Field began during the late 1970s. In 1986, the U.S. Environmental Protection Agency (EPA) mandated a basewide Resource Conservation and Recovery Act facility assessment and hydrogeologic assessment. On February 21, 1990, the entire Edgewood Area was added to the National Priorities List. 
TABLE 1 Major Milestones for the J-Field Geophysics Program

\begin{tabular}{lll}
\hline \multicolumn{1}{c}{ Activity } & \multicolumn{1}{c}{ Dates } & Comment \\
\hline $\begin{array}{l}\text { Field reconnaissance } \\
\text { Submitted Geophysics Work Plan }\end{array}$ & $\begin{array}{l}\text { January 1993 } \\
\text { June 1993 }\end{array}$ & $\begin{array}{c}\text { Includes seismic refraction and reflection, } \\
\text { electromagnetic profiling, electrical depth } \\
\text { sounding, and ground profiling radar. }\end{array}$ \\
$\begin{array}{l}\text { Submitted health and safety plan } \\
\begin{array}{l}\text { Mobilization } \\
\text { Transport } \\
\text { Field data collection }\end{array}\end{array}$ & $\begin{array}{l}\text { Spring 1993 } \\
\text { May 6-12, 1993 } \\
\text { May 13-14, 1993 } \\
\text { July 13-29, 1993 }\end{array}$ \\
\hline
\end{tabular}




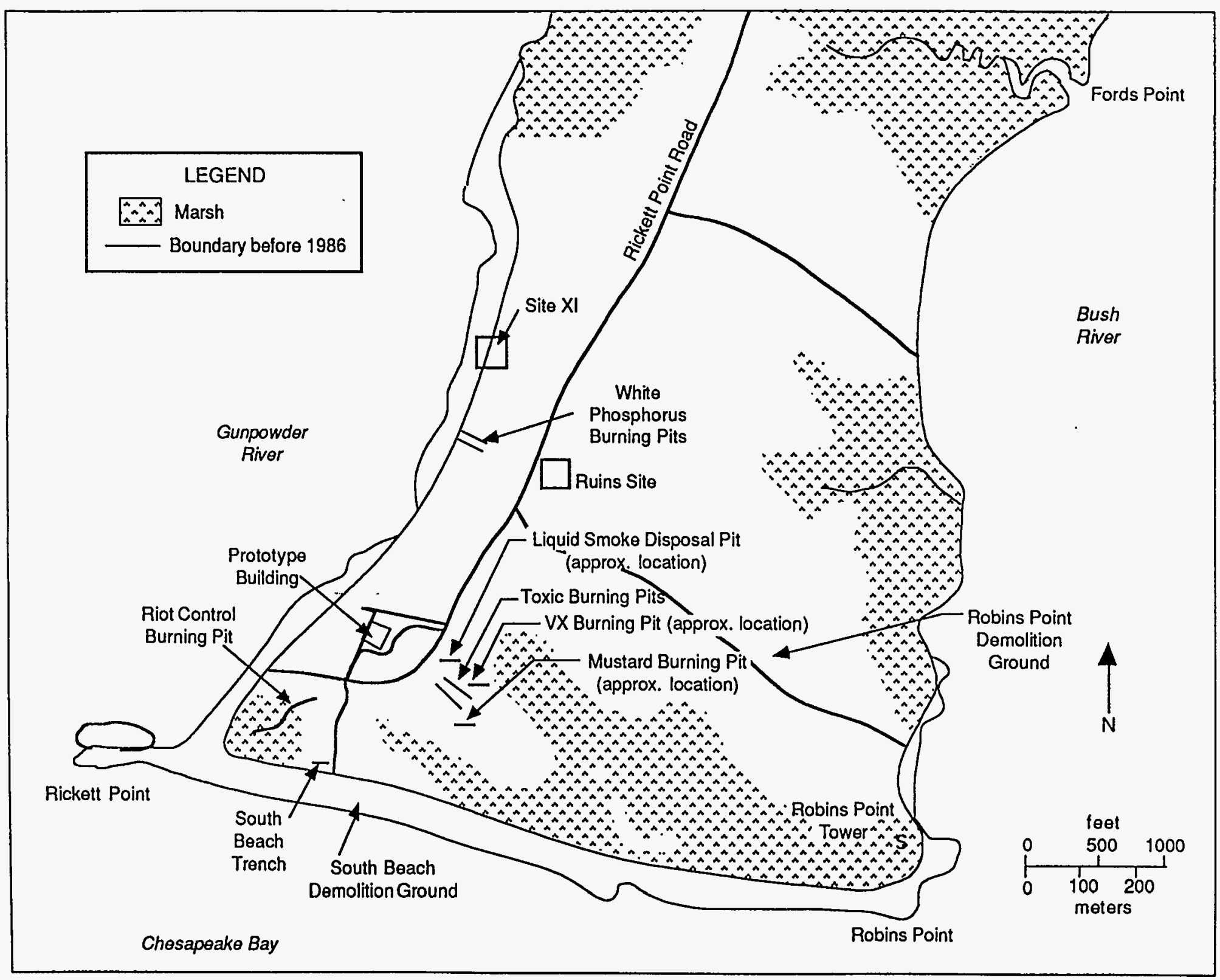

u

FIGURE 2 Locations of Areas of Concern and Principal Site Features at J-Field (Source: Adapted from Hughes 1991) 


\section{Physiographic Setting and Hydrogeology}

J-Field, which occupies approximately 460 acres on the southern tip of the Gunpowder Neck Peninsula, has less than $15 \mathrm{ft}$ of relief. The peninsula is located within the Coastal Plain physiographic province of Maryland and is surrounded by tidal estuaries on three sides: the Gunpowder River to the west, the Chesapeake Bay to the south, and the Bush River to the east. (See Figures 1 and 2.)

Outcrops of the uppermost Pleistocene Talbot Formation are present along the southern shoreline. Further north, within the Edgewood Area of APG, the Talbot Formation becomes relatively thin and horizontally discontinuous (Oliveros and Vroblesky 1989). The Talbot Formation, consisting of interbedded sands, gravels, and silty clays, covers the entire J-Field area and varies in thickness from 110 to $160 \mathrm{ft}$ (Hughes 1993). Based on well log, gamma log, and offshore seismic data, Hughes $(1991,1993)$ identified three hydrogeologic units within the Talbot Formation at J-Field (Figures 3 and 4). Unit $\mathrm{A}$, at the base, is a confined aquifer consisting of 13-50 ft of gravelly sand and clay. Unit B, overlying Unit A, is a leaky confining unit consisting of 36-107 ft of silty, sandy clays with organic matter. The contact between Units A and $B$ dips eastward to a surface elevation of $142 \mathrm{ft}$ below mean sea level (MSL) in the southeast and is $60 \mathrm{ft}$ below MSL in the west. Unit C consists of $25-40 \mathrm{ft}$ of interbedded sands, silts, and clays which are referred to as the surficial aquifer even though it also includes the unsaturated zone (Hughes 1993).

The contact at the base of the Talbot Formation is an angular unconformity underlain by approximately $300-400 \mathrm{ft}$ of Cretaceous (Patapsco Formation) sediments belonging to the Potomac Group (Figure 5). The Cretaceous sediments consist of interbedded layers of finegrained sand and massive clay of fluvial origin. The unconformity between the Pleistocene and Cretaceous sediments is indicative of an erosional contact during a lower sea-level stand in the Pleistocene epoch. The depth of erosion of the Cretaceous deposits and the presence of Pleistocene fluvial sediments overlying the Cretaceous deposits indicate that a major stream channel, such as the ancestral Susquehanna River channel, was located beneath J-Field (Hughes 1993). Pleistocene erosional channels in Cretaceous and Tertiary sediments have been observed elsewhere within the Edgewood Area of APG (Oliveros and Vroblesky 1989) and are a common feature of the Chesapeake Bay region (Kerhin et al. 1988). The offshore seismic profiles conducted around the Gunpowder Neck Peninsula (Figure 4) helped identify the extent of the paleochannel containing the Pleistocene sediments at J-Field (Hughes 1991).

The estimated elevation of the crystalline basement underlying the Patapsco Formation ranges from $350 \mathrm{ft}$ (Owens 1969) to $800 \mathrm{ft}$ (Otton and Mandle 1984) below MSL. Seismic reflection data at Beach Point Peninsula, located about 32,000 ft to the north in the Edgewood Area, APG, indicate a depth to the crystalline basement of around $560 \mathrm{ft}$ (McGinnis 1994). The crystalline basement dips to the southeast at an angle of less than one degree (Bennett and Meyer 1952; Dingman et al. 1956; Southwick, Owens, and Edwards 1969). 


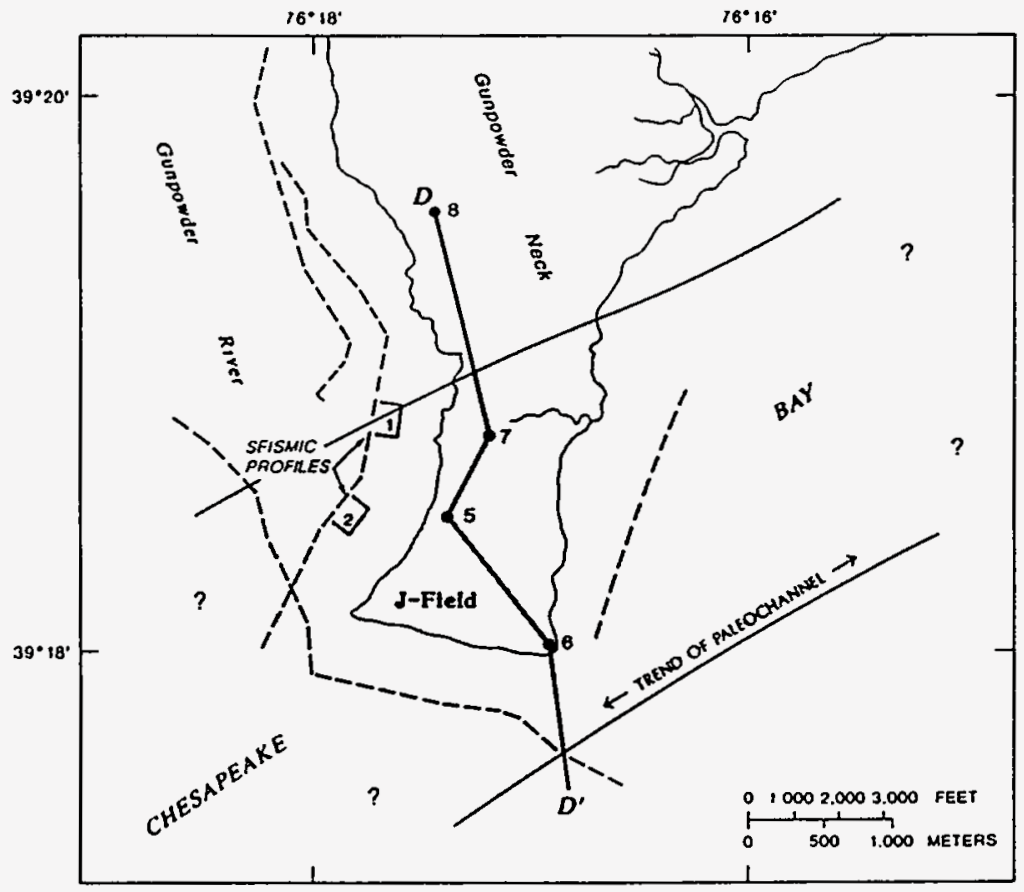

EXPLANATION

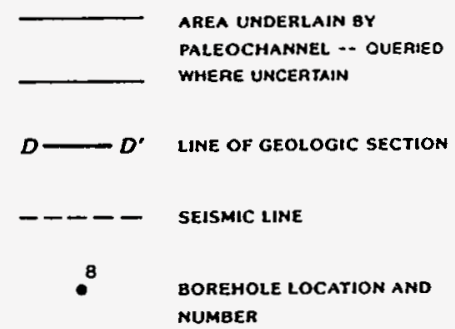

FIGURE 3 Location of Offshore Seismic Lines and Geologic Section D-D' through Pleistocene Sediments (Source: Hughes 1991)

Over 50 monitoring wells have been installed at J-Field by the USGS, U.S. Army Toxic and Hazardous Materials Agency (USATHAMA), and Princeton Aqua Science. Lithologic logs for all three agencies are summarized in Hughes (1993). Well locations are shown in Figure 6. Responsible organization, land-surface elevations, and boring depths are listed for each well in Table 2. 


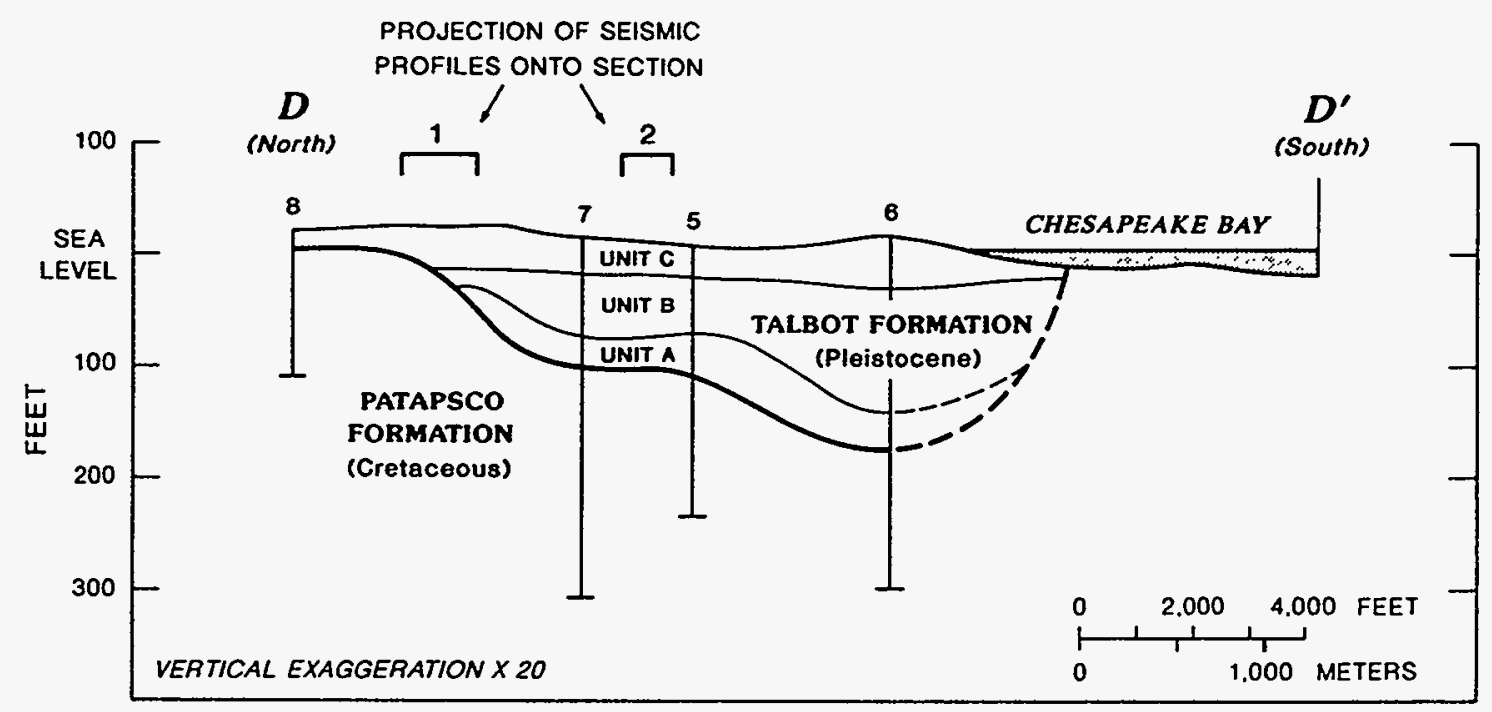

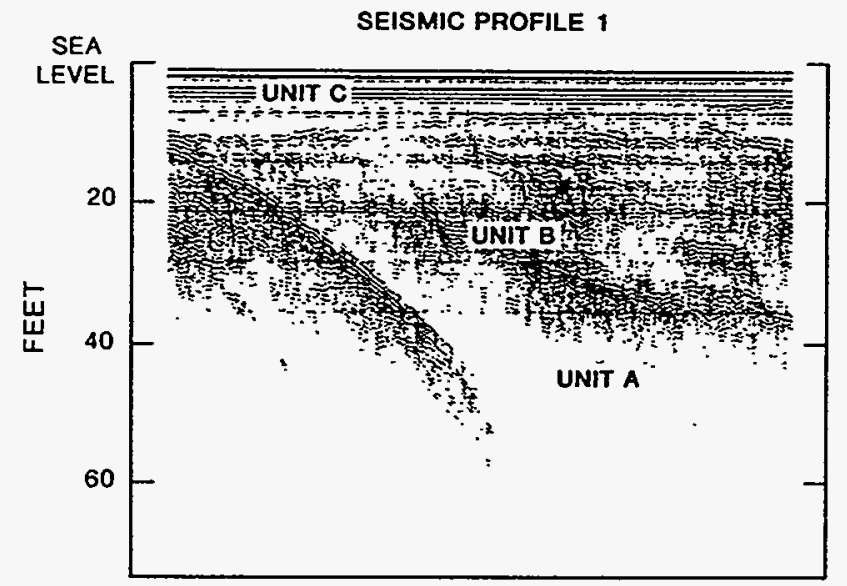

VERTICAL EXAGGERATION $\times 12$

EXPLANATION

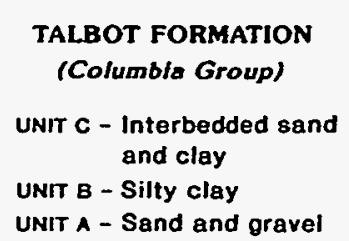

Interbedded fine sand and clay

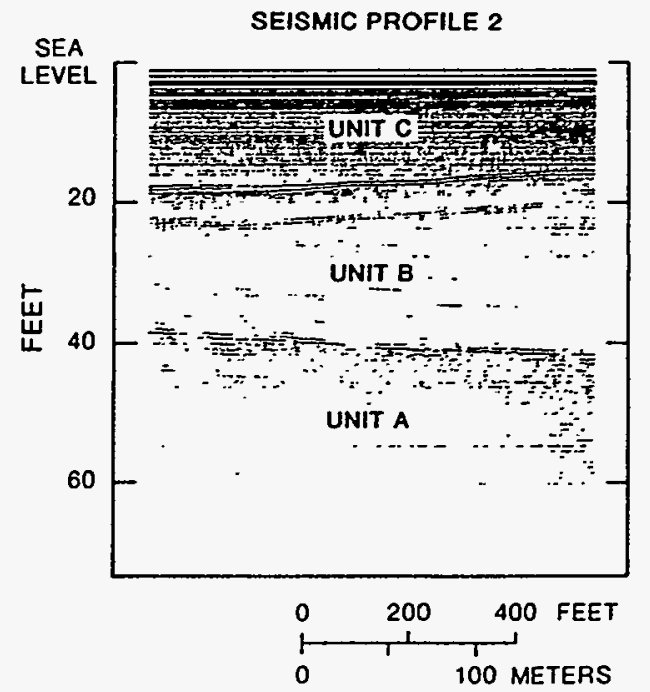

SEISMIC PROFILE 2

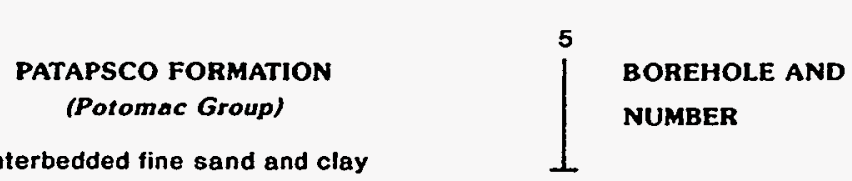

\section{NUMBER}

—- - LITHOLOGIC CONTACT -- DASHED WHERE INFERREO

FIGURE 4 Geologic Section D-D' through Pleistocene Sediments and Offshore Seismic Profiles (Source: Hughes 1991) 


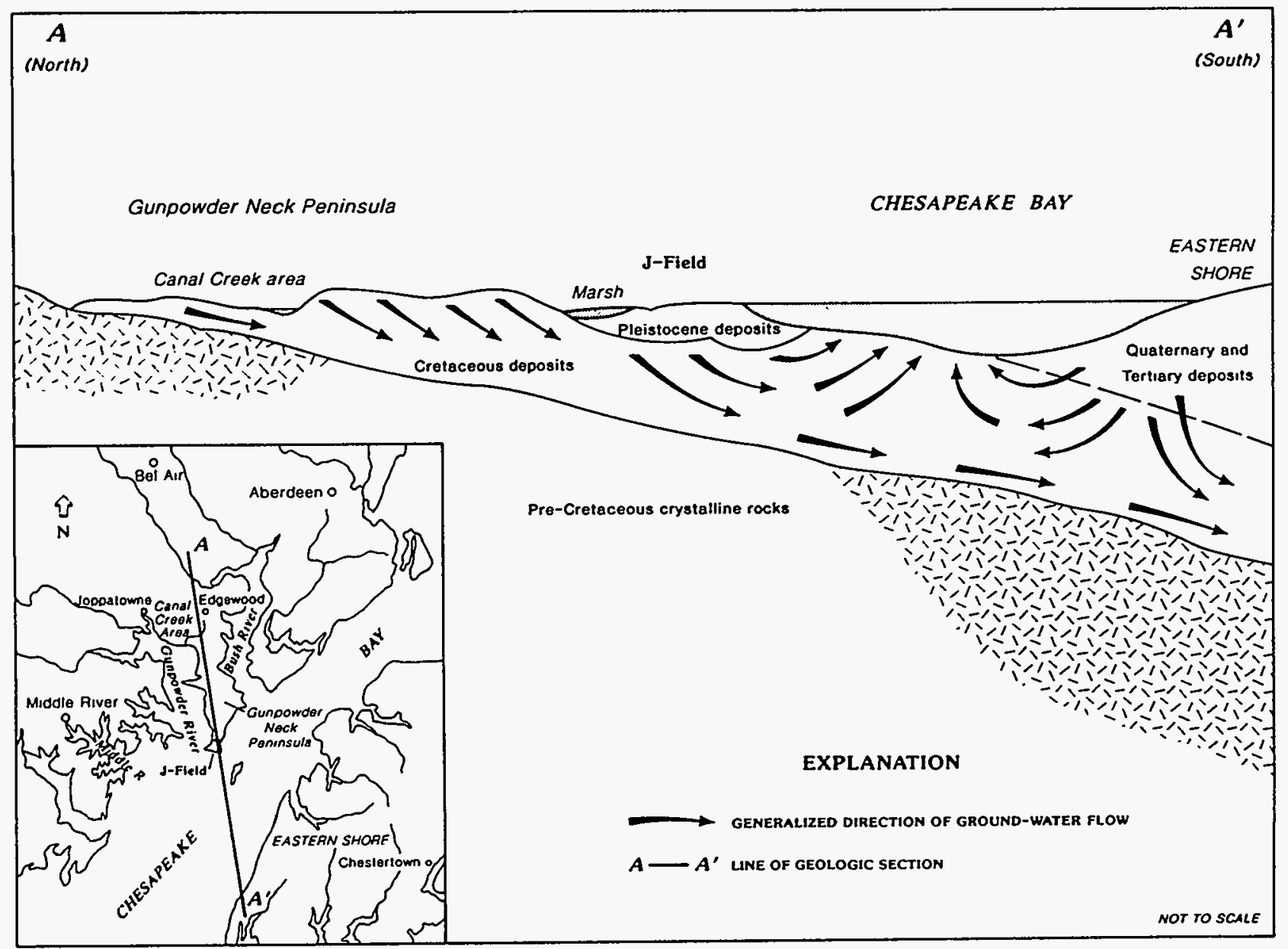

FIGURE 5 Geologic Units and Generalized Directions of Groundwater Flow in the Upper Chesapeake Bay Area (Source: Hughes 1993) 


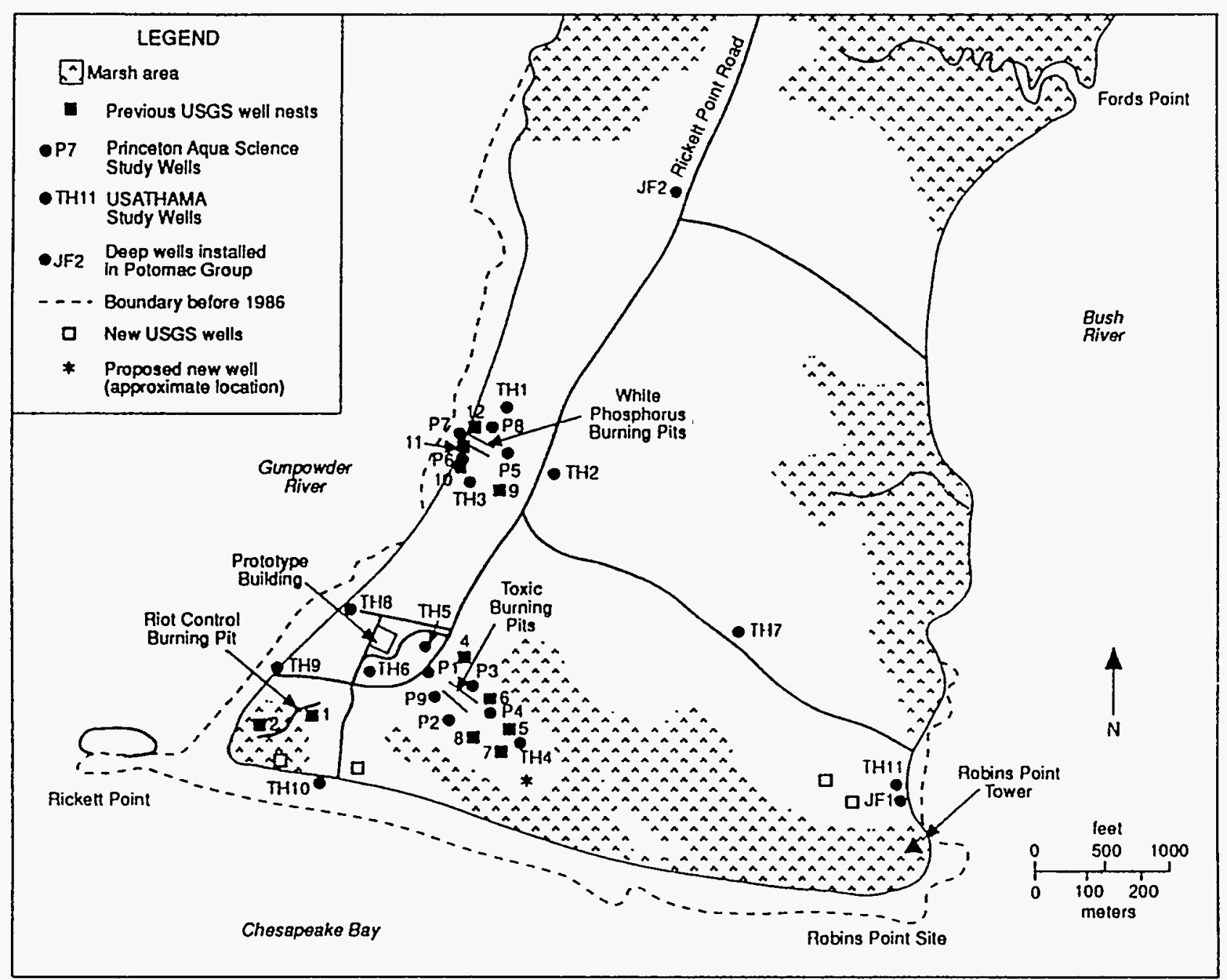

FIGURE 6 Locations of Existing Monitoring Wells at J-Field (Source: Adapted from Hughes 1991) 
TABLE 2 Monitoring Well Depths at J-Field

\begin{tabular}{|c|c|c|c|c|c|c|c|}
\hline \multirow[b]{2}{*}{$\begin{array}{l}\text { Well } \\
\text { Nos. }\end{array}$} & \multirow{2}{*}{$\begin{array}{l}\text { Responsible } \\
\text { Organization }\end{array}$} & \multicolumn{3}{|c|}{ Surface Elevation (ft MSL) } & \multicolumn{3}{|c|}{ Depth of Boring ( $\mathrm{ft}$ ) } \\
\hline & & Well 1 & Well 2 & Well 3 & Well 1 & Well 2 & Well 3 \\
\hline JF 1 & USGS & 4.95 & & & 190 & & \\
\hline JF2 & & & $n a^{a}$ & & & 300 & \\
\hline$J F 11,12,13^{b}$ & USGS (Cluster 1 ) & 7.42 & 7.30 & 7.18 & 90 & 55 & 25.5 \\
\hline JF21, 22, 23 & USGS (Cluster 2) & 2.99 & 2.99 & 3.10 & 71 & 52.5 & 19 \\
\hline JF31, 32, 33 & USGS (Cluster 3 ) & 7.67 & 7.70 & 7.79 & 81.3 & 54.4 & 20 \\
\hline JF41, 42, 43 & USGS (Cluster 4) & 10.22 & 10.30 & 10.63 & 90 & 62 & 35 \\
\hline JF51, 52,53 & USGS (Cluster 5) & 5.02 & 5.27 & 5.10 & 115 & 65 & 19.2 \\
\hline$J F 61,62,63$ & USGS (Cluster 6) & 4.29 & 4.08 & 4.10 & 100 & 65 & 19 \\
\hline JF71, 72,73 & USGS (Cluster 7) & 7.26 & 8.28 & 7.48 & 125 & 81 & 18 \\
\hline JF81, 82, 83 & USGS (Cluster 8) & 10.01 & 10.39 & 10.42 & 123 & 75 & 20 \\
\hline IF91, 92, 93 & USGS (Cluster 9; & $i 0.18$ & 10.60 & 10.28 & 79 & 55.5 & 25 \\
\hline JF101, 102, 103 & USGS (Cluster 10) & 5.36 & 5.70 & 5.41 & 76 & 55 & 28 \\
\hline JF111, 112,113 & USGS (Cluster 11) & 6.51 & 6.19 & 6.77 & 75 & 50 & 25 \\
\hline$J F 121,122,123$ & USGS (Cluster 12) & 4.16 & 4.42 & 4.15 & 70 & 55 & 28 \\
\hline JF131, 132, 133 & USGS (Cluster 13) & na & na & na & na & na & na \\
\hline$J F 141, \quad 142, \quad 143$ & USGS (Cluster 14) & na & na & na & na & na & na \\
\hline JF151, $152, \quad 153$ & USGS (Cluster 15) & na & na & na & na & na & na \\
\hline JF161, $162, \quad 163$ & USGS (Cluster 16) & na & na & na & na & na & na \\
\hline JF171, 172,173 & USGS (Cluster 17) & na & na & 6 & na & na & 33.0 \\
\hline TH1 & USATHAMA & 3.44 & & & 16 & & \\
\hline TH2 & USATHAMA & 9.45 & & & 18 & & \\
\hline TH3 & USATHAMA & 6.07 & & & 18 & & \\
\hline TH4 & USATHAMA & 4.36 & & & 18 & & \\
\hline TH5 & USATHAMA & 8.27 & & & 20 & & \\
\hline TH6 & USATHAMA & 8.83 & & & 20 & & \\
\hline TH7 & USATHAMA & 4.72 & & & 17 & & \\
\hline TH8 & USATHAMA & 5.31 & & & 17 & & \\
\hline TH9 & USATHAMA & 4.82 & & & 18 & & \\
\hline TH10 & USATHAMA & 7.19 & & & 18 & & \\
\hline TH11 & USATHAMA & 4.10 & & & 18 & & \\
\hline P1 & PRIN AQ SCIC & na & & & 20 & & \\
\hline $\mathrm{P} 2$ & PRIN AQ SCI & na & & & 20 & & \\
\hline P3 & PRIN AQ SCI & na & & & 20 & & \\
\hline $\mathrm{P4}$ & PRIN AQ SCI & na & & & 20 & & \\
\hline P5 & PRIN AQ SCI & na & & & 17 & & \\
\hline P6 & PRIN AQ SCI & na & & & 17 & & \\
\hline P7 & PRIN AQ SCI & na & & & 20 & & \\
\hline P8 & PRIN AQ SCI & na & & & 20 & & \\
\hline P9 & PRIN AQ SCI & na & & & 17 & & \\
\hline
\end{tabular}

a $\mathrm{na}=$ not available.

b Wells are identified by cluster number. Wells JF 11, 12, 13 are identified as cluster 1; Wells JF 21, 22, 23 are identified as cluster 2; etc.

c PRIN AQ SCI = Princeton Aqua Sciences. 


\section{Geophysical Studies}

Geophysical surveys were conducted at several locations in the J-Field study area, including (1) sites where activities resulting in ground contamination are known or suspected to have occurred in the past and (2) locations that are relatively undisturbed at the surface but are suspected to have been affected by the migration of contaminated groundwater from nearby contaminated sites. Both area and line geophysical surveys were performed.

Prior to field operations by ANL staff, J-Field sites were screened by personnel specially trained in unexploded ordnance removal. As an additional precaution, ANL staff scanned survey locations using a Schonstedt magnetic (MAC-51B) gradiometer prior to deploying grid coordinate stakes, geophone spikes, electrical resistivity electrodes, or seismic sources. (The Schonstedt magnetic gradiometer and cable locator is a dual-mode instrument designed for detecting shallow buried iron and steel objects and for tracing underground cables and pipes. The system consists of a transmitter anis a dua:-furction receiver designed to detect aroinaious magnetic gradients.)

\subsection{Instrumentation and Software}

Instruments used in geophysical data acquisition at J-Field include an EG\&G Geometrics ES-2401 24-channel seismograph; an ABEM Terrameter electrical resistivity system; a Geonics Inc., EM-31 electrical conductivity meter; an EG\&G Geometrics cesium vapor magnetometer; and a SIR-3 ground-penetrating radar (GPR) unit with a monostatic antenna. Seismic source data were acquired using a Bison elastic-wave generator (EWG) for deeper surveys and a sledgehammer for shallow reflection surveys.

Initial data reduction of electromagnetic and magnetic data was accomplished using a DAT31 software routine provided by Geonics. Data gridding and contouring were accomplished using MINC minimum curvature gridding software produced by the USGS, SURFER software developed by Golden Software, Inc., and COLORMAP software developed at ANL. Seismic refraction data were processed using SIPT by Rimrock Software, Inc.; seismic reflection data were processed using EAVESDROPPER software produced by Interactive Concepts and SEISX developed at ANL. Resistivity data were processed using RESIXP software developed by Interpex, Inc. RADAN-3 software by Geophysical Survey Systems, Inc. (GSSI) was used to process GPR imaging data.

\subsection{Establishment of Survey Areas}

Five polygon-shaped survey areas were established as part of the geophysical investigations conducted at J-Field, including the TBP, WPP, RCP sites, between the PBW and the Gunpowder River, and around Well JF133. Locations for the geophysical surveys are shown 
in Figure 7. The location, coordinate system, orientation, and size of each area are summarized in Table 3. Geophysical investigations were tied into the coordinate systems established for each survey area, but were not necessarily confined by the boundaries established for the area. Corners for the TBP, WPP, and PBW sites were professionally surveyed. The three areas are shown in Figures 8 and 9. Corner coordinates for these areas are listed in Table 4.

Some geophysical measurements were conducted at locations other than the formal surveyed areas; for example, an electromagnetic profile was made along the south shore of the Gunpowder Neck Peninsula. Also, seismic and electrical resistivity profiles were conducted between some of the geophysical survey areas, including profiles along Rickett Point Road from the WPP site to TBP site and across the western third of Gunpowder Neck Peninsula from the Gunpowder River along the northern boundaries of the PBW and TBP sites. Detailed descriptions, indicating locations of each geophysical investigation, are provided in the following sections.

\subsection{Seismic Investigations}

One seismic refraction and nine seismic reflection profiles were recorded at J-Field to image the Pleistocene and Cretaceous sedimentary units (see locations in Figure 10). Note that two profiles, Lines REFR-1 and 1-DP, overlay one another, and Line 1 overlies the northern ends of line REFR-1 and line 1-DP. The leaky confining unit at the base of the surficial aquifer (Unit B of Hughes 1991) was the primary target for the seismic surveys.

A 24-channel engineering seismograph (EG\&G ES-2401) with geophone cables of 1-m, 2-m, and 10-m group intervals (geophone spacing) was used to determine the depth and seismic velocity of the underlying strata. The geophones had natural frequencies of $12-\mathrm{Hertz}(\mathrm{Hz})$ for the refraction data and $40-\mathrm{Hz}$ for the reflection profiling. Seismic sources consisted of both a 16-lb sledgehammer and a trailer-mounted EWG. In some cases, multiple shots were stacked to increase the signal-to-noise ratio. The sledgehammer-generated energy penetrated to depths of approximately $100 \mathrm{ft}$ or less, while the EWG-generated energy penetrated to depths of a few hundred feet. On-site analysis and quality control of the seismic data were conducted using the SIPT refraction programs produced by Rimrock Software.

\subsubsection{Seismic Refraction Survey}

Seismic refraction profiling was used to measure the velocity and structural trend of sedimentary units in the Talbot Formation underlying J-Field. Shot points were placed in-line with an array of geophones. The seismic refraction method can only detect increases in seismic wave velocity with depth. Low-velocity layers are transparent to refracted energy and must be imaged using seismic reflection or other methods. 


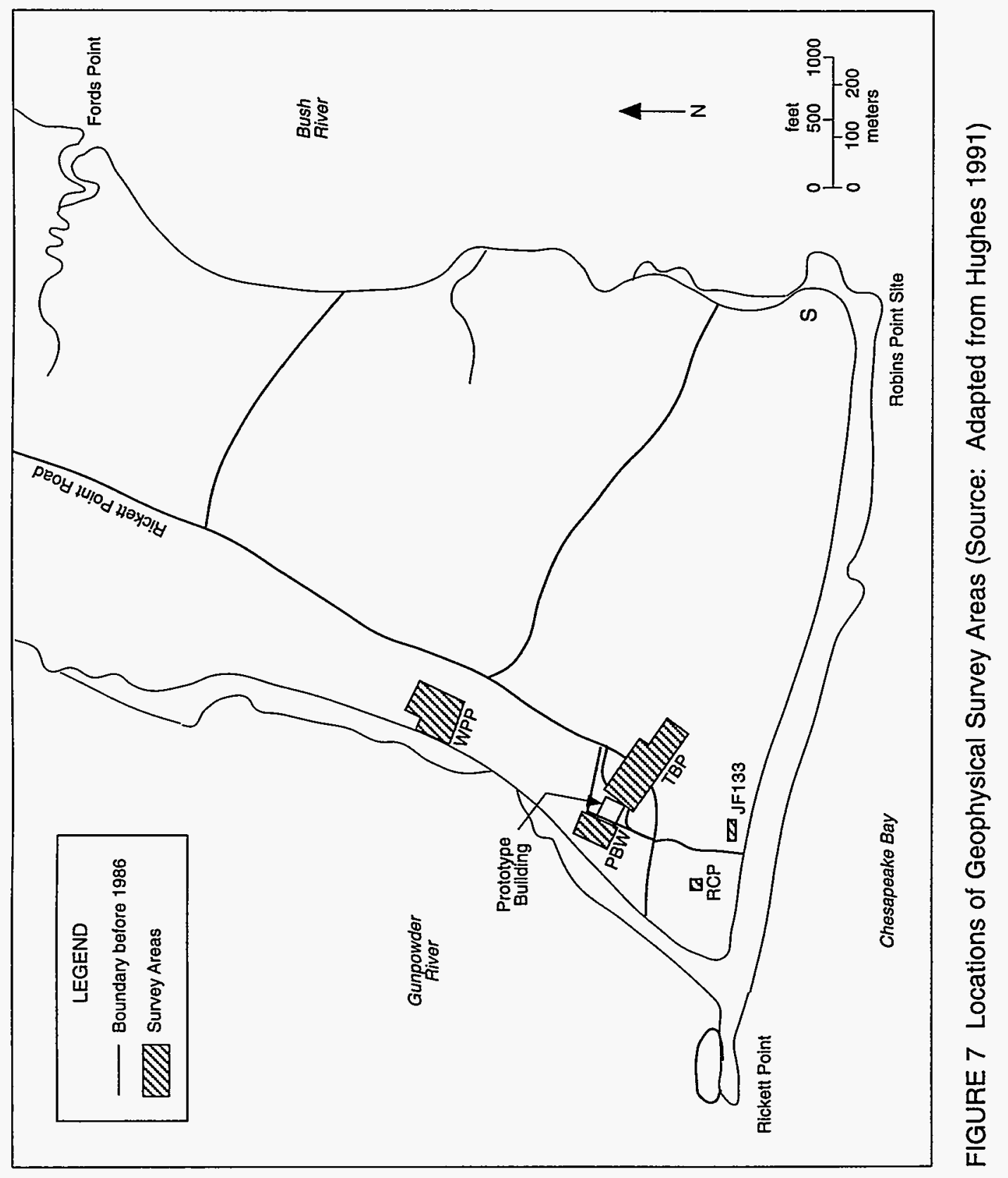


TABLE 3 Grid Specifications for Geophysical Survey Areas

\begin{tabular}{|c|c|c|c|c|c|}
\hline \multirow{2}{*}{$\begin{array}{l}\text { Geophysical } \\
\text { Survey } \\
\text { Area }\end{array}$} & \multicolumn{2}{|c|}{ Dimensions ( $\mathrm{ft}$ ) } & \multirow{2}{*}{$\begin{array}{l}\text { Y-Axis } \\
\text { Orientation } \\
\text { (deg) }\end{array}$} & \multirow{2}{*}{$\begin{array}{l}\text { Area } \\
\left(\mathrm{ft}^{2}\right)\end{array}$} & \multirow[b]{2}{*}{ Location } \\
\hline & $X(E-W)$ & $Y(N-S)$ & & & \\
\hline TBP & 670 & 260 & N36E & 165,000 & $\begin{array}{l}\text { Professionally surveyed: }{ }^{a} \text { Located east } \\
\text { of the Prototype Building, immediately } \\
\text { surrounding the toxic burning pits. }\end{array}$ \\
\hline WPP & 330 & 490 & N24E & 154,000 & $\begin{array}{l}\text { Professionally surveyed: a Located } \\
\text { between Rickett Point Road and the } \\
\text { western shore, immediately } \\
\text { surrounding the white phosphorus } \\
\text { burning pits. }\end{array}$ \\
\hline PBW & 230 & 290 & N30E & 67,000 & $\begin{array}{l}\text { Professionally surveyed: }{ }^{\mathrm{a}} \text { Located } \\
\text { between the Prototype Building and the } \\
\text { western shore. }\end{array}$ \\
\hline $\mathrm{RCP}$ & 160 & 170 & NOE & 27,000 & $\begin{array}{l}\text { Roughly surveyed: b Located imme- } \\
\text { diately east of the trench. The } \\
\text { western edge of the RCP site is } \\
\text { located } 260 \mathrm{ft} \text { west of South Beach } \\
\text { Road. One well from USGS well } \\
\text { cluster } 1 \text { coincides with the RCP grid } \\
\text { coordinate }(13 E, 22 S) \text {. }\end{array}$ \\
\hline JF133 & 150 & 50 & NOE & 7,500 & $\begin{array}{l}\text { Roughly surveyed: } \mathrm{b} \text { Located near the } \\
\text { southern shore approximately } 300 \mathrm{ft} \\
\text { east of South Beach Road. Well JF133 } \\
\text { coincides with grid coordinate (150E, } \\
20 \mathrm{~S} \text { ). }\end{array}$ \\
\hline
\end{tabular}

a Corner locations for the TBP, WPP, and PBW geophysical survey areas are listed in State Plane Coordinates in Table 4. Detailed maps showing elevations, well locations, and other features are shown in Figures 8 and 9.

b The RCP and JF133 geophysical survey areas were not professionally surveyed. The $\mathrm{Y}$-axis orientation was aligned with magnetic north using a Brunton compass. 


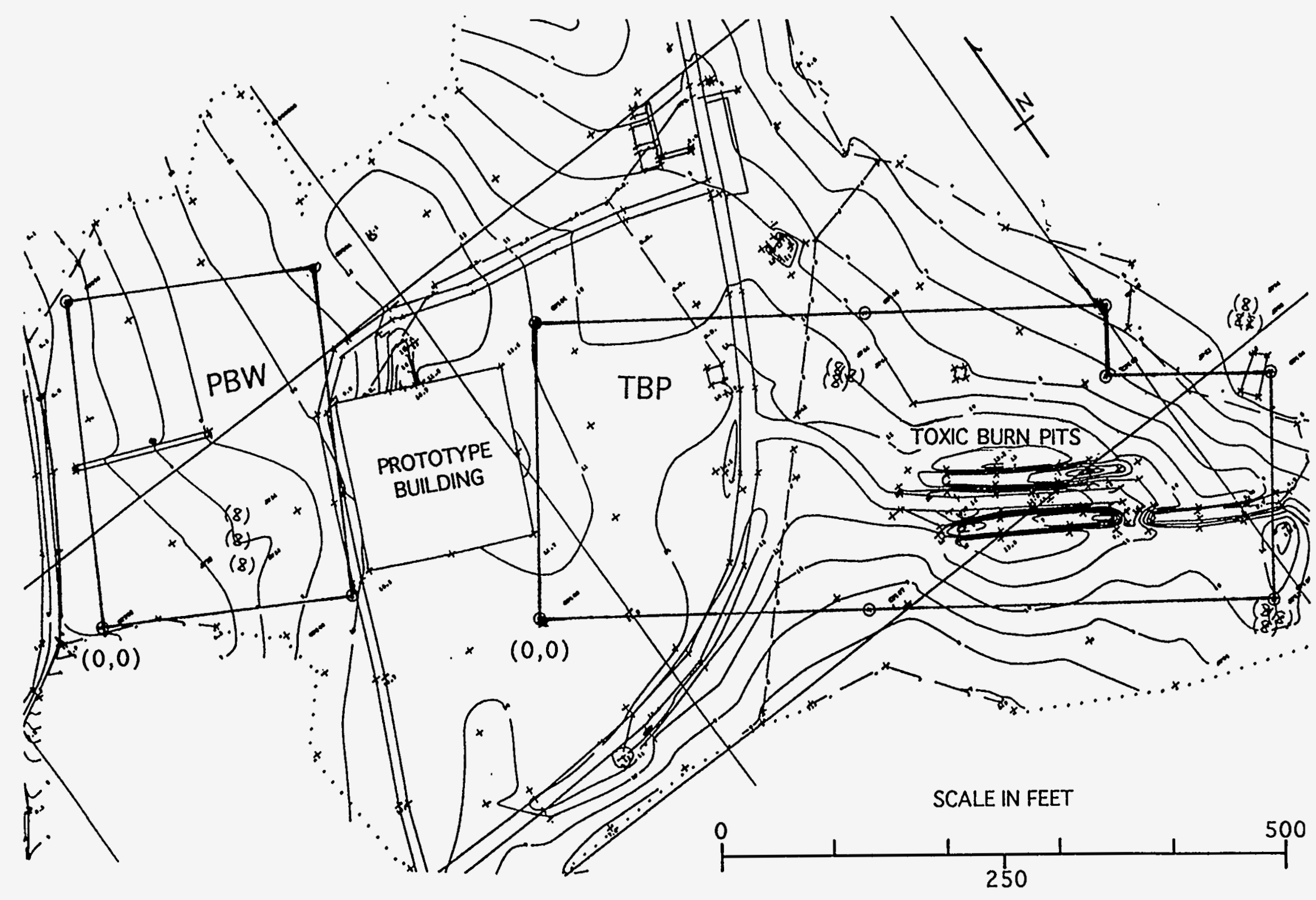

FIGURE 8 Detailed Map of the TBP and PBW Geophysical Survey Sites 


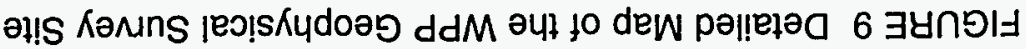

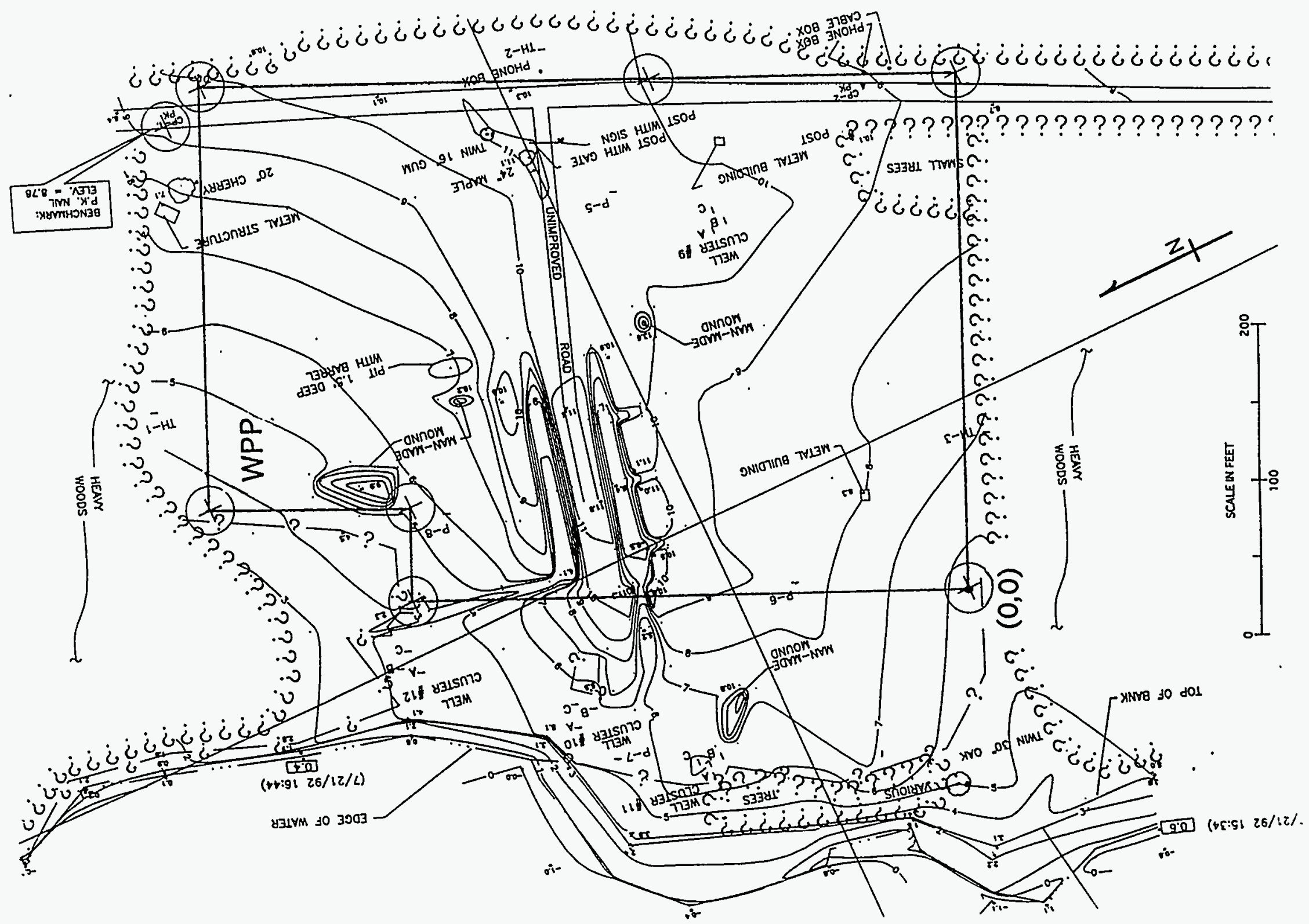


TABLE 4 Corner Coordinates for Geophysical Survey Areas

\begin{tabular}{|c|c|c|c|c|c|c|}
\hline \multirow{2}{*}{$\begin{array}{c}\text { Control } \\
\text { Point } \\
\text { No. }\end{array}$} & \multirow[b]{2}{*}{$\begin{array}{c}\text { Survey } \\
\text { Area }\end{array}$} & \multicolumn{2}{|c|}{ State Plane Coordinates } & \multirow[b]{2}{*}{$\begin{array}{l}\text { Elevation } \\
(\mathrm{ft})\end{array}$} & \multicolumn{2}{|c|}{ Grid Location } \\
\hline & & Northing (ft) & Easting (ft) & & $X(\mathfrak{f t})$ & $Y(\mathrm{ft})$ \\
\hline 100 & TBP & $536,195.5$ & $999,931.9$ & 10.8 & 0 & 0 \\
\hline 101 & TBP & $536,406.7$ & $1,000,083.4$ & 11.3 & 0 & 260 \\
\hline 102 & TBP & $536,103.6$ & $1,000,505.9$ & 5.4 & 520 & 260 \\
\hline 103 & TBP & $536,054.8$ & $1,000,471.0$ & 8.0 & 520 & 200 \\
\hline 104 & TBP & $535,967.4$ & $1,000,592.9$ & 4.3 & 670 & 200 \\
\hline 105 & TBP & $535,804.9$ & $1,000,476.3$ & $n a^{a}$ & 670 & 0 \\
\hline 106 & TBP & $536,231.8$ & $1,000,327.2$ & 8.5 & 300 & 260 \\
\hline 107 & TBP & $536,020.5$ & $1,000,175.6$ & 9.7 & 300 & 0 \\
\hline 2.00 & PBW & $536,314.9$ & $999,808.5$ & 9.6 & 230 & 0 \\
\hline 201 & PBW & $536,566.4$ & $999,952.9$ & 11.6 & 230 & 290 \\
\hline 202 & PBW & $536,681.0$ & $999,753.5$ & 6.7 & 0 & 290 \\
\hline 203 & PBW & $536,429.5$ & $999,609.1$ & 5.9 & 0 & 0 \\
\hline 300 & WPP & $537,227.1$ & $1,000,689.3$ & 8.5 & 330 & 0 \\
\hline 301 & WPP & $537,409.7$ & $1,000,770.2$ & 9.6 & 330 & 200 \\
\hline 302 & WPP & $537,674.9$ & $1,000,887.7$ & 9.0 & 330 & 490 \\
\hline 303 & WPP & $537,784.0$ & $1,000,640.8$ & 3.7 & 60 & 490 \\
\hline 304 & WPP & $537,666.1$ & $1,000,588.3$ & 5.4 & 60 & 360 \\
\hline 305 & WPP & $537,690.0$ & $1,000,533.5$ & na & 0 & 360 \\
\hline 306 & WPP & $537,360.5$ & $1,000,388.4$ & 5.5 & 0 & 0 \\
\hline 1012 & $\mathrm{BM}^{\mathrm{b}}$ & $537,705.6$ & $1,000,874.3$ & 8.7 & $\cdots$ & $\cdots$ \\
\hline
\end{tabular}

${ }^{\mathrm{a}} \mathrm{na}=$ not available.

b Bench Mark located near the WPP site.

A single seismic refraction profile (REFR-1) was recorded along Rickett Point Road. The profile, 1,995 $\mathrm{ft}$ in length, was located between the WPP and TBP sites (Figure 10). The north end of REFR-1 is located $574 \mathrm{ft}$ north of the service road to the WPP site. Three overlapping refraction spreads comprised the profile. Geophones were placed at 32.8-ft intervals and the maximum shot-to-detector distance used was $1,870 \mathrm{ft}$. The profile recording parameters for line REFR-1, as used during the field survey, are shown in Table 5. A three-layer velocity model was constructed by interpreting the time-distance data from Line REFR-1 (Figure 11). The velocitydepth cross-section for the model is shown in Figure 12.

The first layer in the model has a direct arrival velocity of 2,310 ft per second $(\mathrm{ft} / \mathrm{s})$ and represents unsaturated sediments that correspond to Unit C of Hughes (1991). The first refractor 


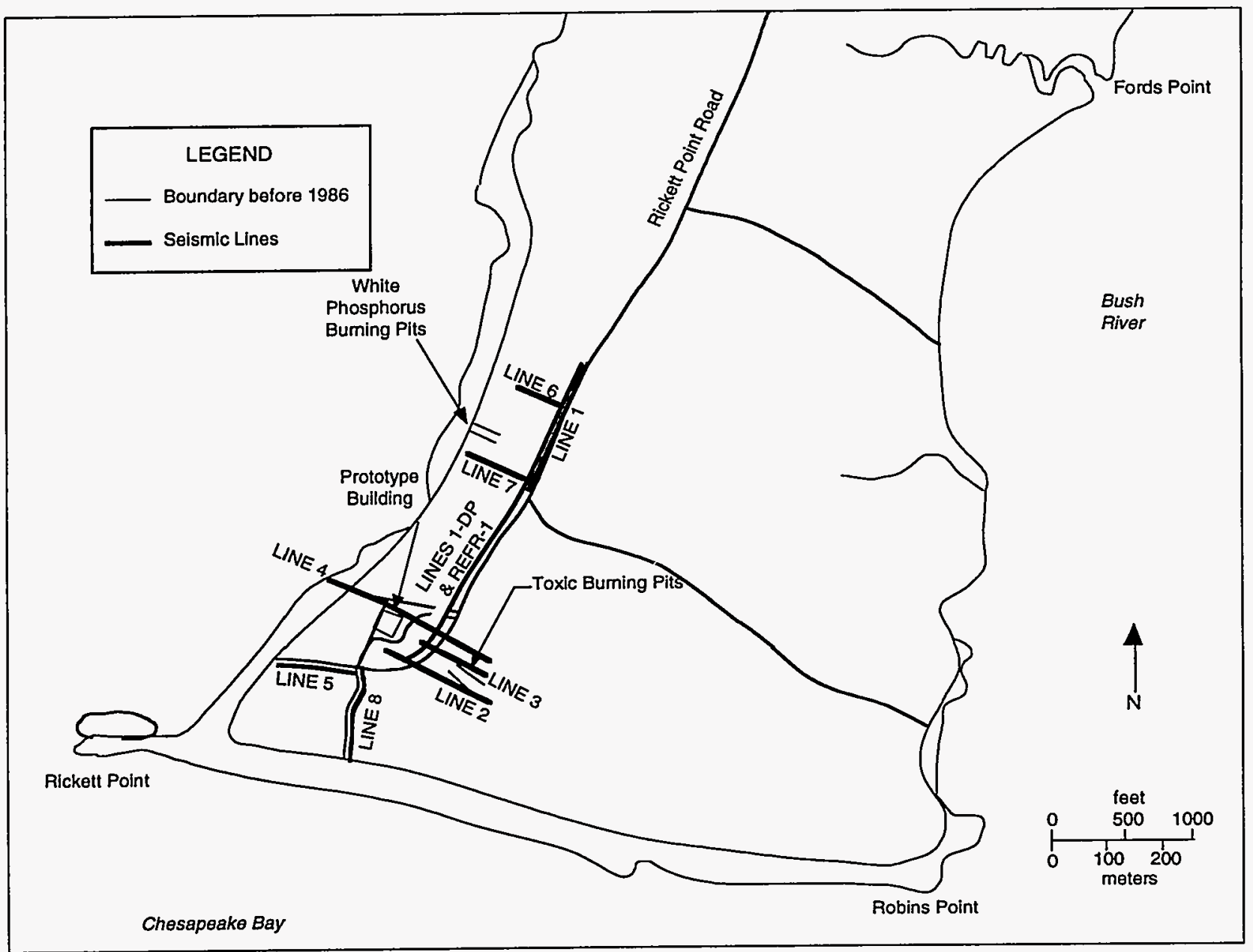

FIGURE 10 Locations of ANL Seismic Refraction and Reflection Profiles (Source: Adapted from Hughes 1991)

TABLE 5 Seismic Refraction Parameters for Line REFR-1

Total length (m)

Total number of shots

Energy source

Geophones per spread

Spread overlap (geophones)

Number of spreads

Geophone interval (m)

Shot point interval

Offset between shot and 1st geophone $(\mathrm{m})$

Max shot-to-geophone distance (m)
608

21

Bison EWG

24

12

3

10

Variable

5

570 


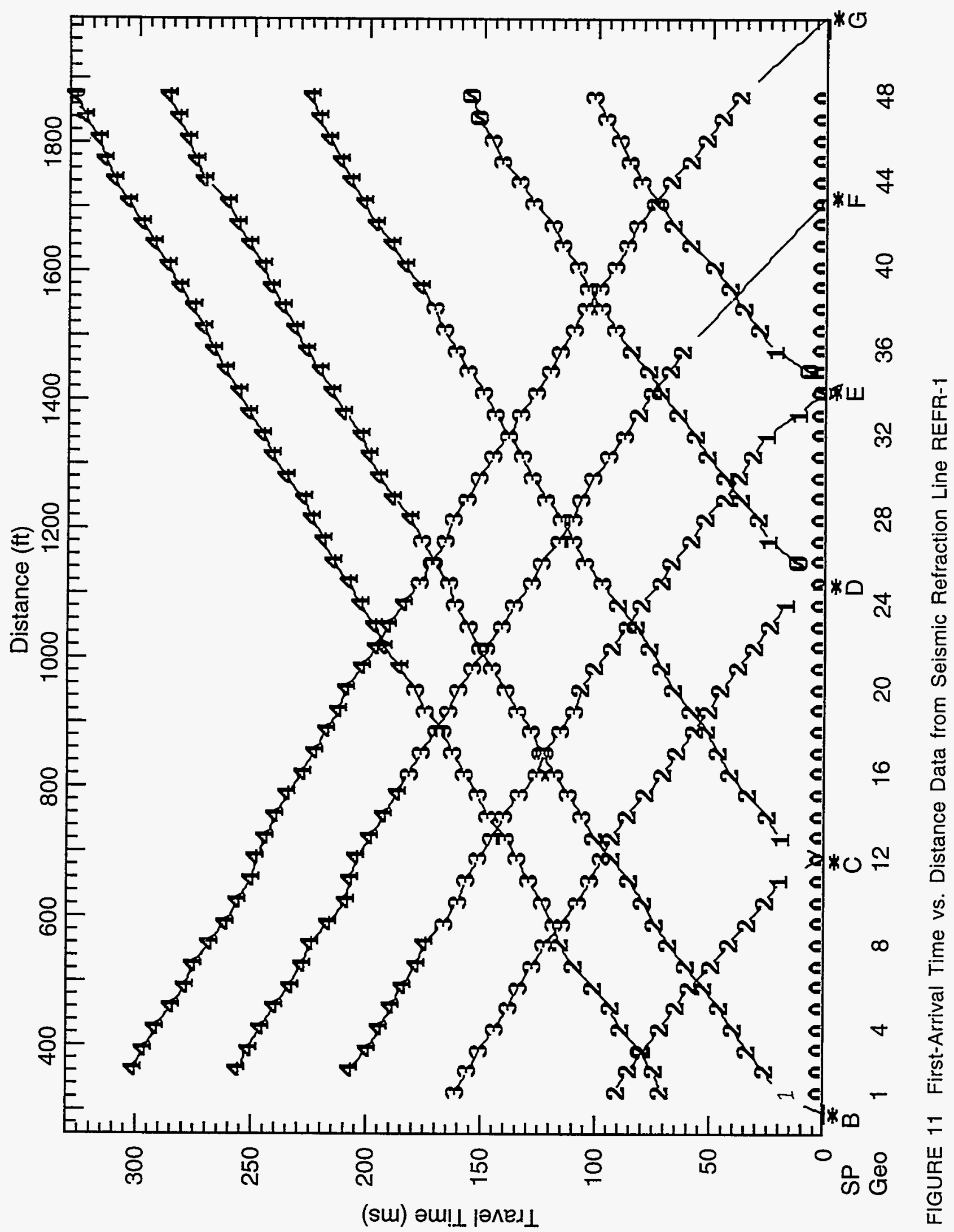




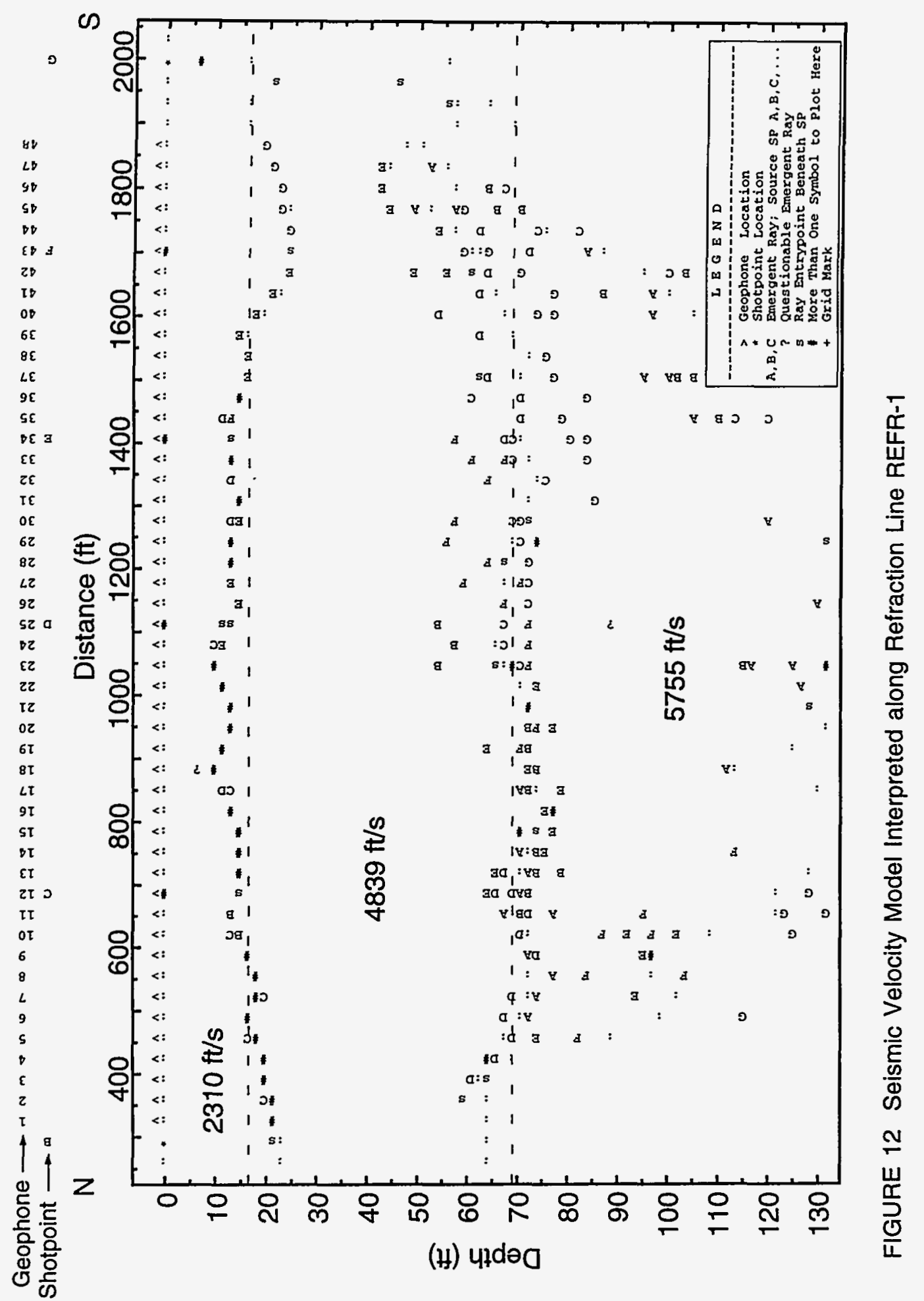


underneath this layer is not a lithologic boundary but may correspond to the water table. The seismic wave velocity averages $4,839 \mathrm{ft} / \mathrm{s}$ and is approximately equal to a saturated silt and clay velocity of $4,865 \mathrm{ft} / \mathrm{s}$. The depth to the first refractor interpreted from refraction data appears to be $16 \mathrm{ft}$. However, the depth is poorly constrained due to the lack of first-arrival data near the source. The actual depth of the water table is less than $10 \mathrm{ft}$. Areas where the refractor appears to shallow may be underlain by higher-velocity, near-surface sediments.

The second layer comprises both the lower, water-saturated portion of Unit $\mathrm{C}$ and the underlying Unit B of Hughes (1991). The top of Unit B was not directly imaged by the seismic refraction, likely because the seismic velocity of the upper part of Unit B is similar to or less than Unit C. A substantially lower velocity in the upper part of Unit B could result from the presence of gas. Low-velocity layers are inherently transparent in seismic refraction methods and can also result in erroneously deep depth estimates for all underlying layers.

The top of the third layer in the model, at a depth of about $69 \mathrm{ft}$, shows a subtle increase in velocity to 5,755 ft/s. Hughes (1993) places the top of Unit A at approximately the same depth $(70-80 \mathrm{ft})$ in the vicinity of the refraction survey. The top of the third layer may be associated with a lithologic change at the contact between Units A and B or with velocity variations within Unit B at a shallower depth.

\subsubsection{Seismic Reflection Survey}

A total of nine seismic reflection profiles, comprising 5,326 linear feet, were recorded at J-Field. Figure 10 shows the locations for the seismic reflection profiles, and Table 6 lists the shot-receiver geometries used for each profile. Detailed maps are shown in Figure 13 for seismic lines in the TBP, PBW, and RCP areas and in Figure 14 for seismic lines in the WPP area.

Seismic line 1-DP, which is the only line recorded with a 2-m group interval, was recorded using a Bison EWG for the seismic source. A greater geophone spacing and longer record time was used for line 1-DP than the other lines in order to image sedimentary rocks to a depth of about $300 \mathrm{ft}$. The other eight lines were recorded using a 16-lb hammer for the seismic source with a $1-\mathrm{m}$ group interval. These lines were designed to observe seismic reflections in the depth range of $30-150 \mathrm{ft}$.

Seismic reflection data were processed using the EAVESDROPPER software produced by Interactive Concepts, Inc. Processing steps included trace editing and muting, bandpass filtering, velocity analysis, common-depth-point sorting and stacking, and topographic compensation. 
TABLE 6 Seismic Reflection Parameters

\begin{tabular}{|c|c|c|c|c|c|c|c|c|}
\hline Line-ID & $\begin{array}{l}\text { Orien- } \\
\text { tation }\end{array}$ & $\begin{array}{l}\text { Line } \\
\text { Location }\end{array}$ & $\begin{array}{c}\text { Shot } \\
\text { Interval } \\
\text { (m) }\end{array}$ & $\begin{array}{l}\text { Group } \\
\text { Interval } \\
(m)\end{array}$ & $\begin{array}{l}\text { Offset } \\
(\mathrm{m})\end{array}$ & $\begin{array}{l}\text { First } \\
\text { Shot } \\
\text { Nos. }\end{array}$ & $\begin{array}{l}\text { Last } \\
\text { Shot } \\
\text { Nos. }\end{array}$ & $\begin{array}{l}\text { Length } \\
(\mathrm{ft})\end{array}$ \\
\hline \multicolumn{9}{|l|}{ Deep } \\
\hline Line 1-DP & N-S & Rickett Pt. Rd. & 2 & 2 & 10 & 2,001 & 2,252 & 1,650 \\
\hline \multicolumn{9}{|l|}{ Shallow } \\
\hline Line 1 & N-S & WPP & 1 & 1 & 12 & 1,001 & 1,144 & 475 \\
\hline Line 6 & $E-W$ & WPP & 1 & 1 & 12 & 1,001 & 1,060 & 196 \\
\hline Line 7 & $E-W$ & WPP & 1 & 1 & 12 & 1,061 & 1,156 & 315 \\
\hline Line 2 & W-E & TBP & 1 & 1 & 10 & 3,001 & 3,202 & 665 \\
\hline Line 3 & $W-E$ & TBP & 1 & 1 & 15 & 4,001 & 4,091 & 300 \\
\hline Line: & $W-E$ & TBP-PBW & $i$ & 1 & 12 & 5,001 & 5,287 & 940 \\
\hline Line 5 & $E-W$ & S. Rickett Pt. Rd. & 1 & 1 & 12 & 1,001 & 1,084 & 275 \\
\hline \multirow[t]{2}{*}{ Line 8} & N-S & S. Beach Rd. & 1 & 1 & 12 & 1,001 & 1,156 & 510 \\
\hline & & & & & & Total & Length: & 5,326 \\
\hline
\end{tabular}

At J-Field, stacking velocities were somewhat lower than what would normally be expected for water-saturated sediments, suggesting the presence of gas. Based on refraction data interpretations and normal moveout analyses, a constant stacking velocity of 3,937 ft/s provided the best overall coherency of stacked seismic sections and was used for generating most of the figures in this section. Analyses of refraction velocities, well logs, gamma logs, and normal move-out curves were used to identify reflectors and determine the depth scale in each of the sections.

The distance scales of all reflection lines are in feet and are generally referenced to either the TBP or WPP coordinate system for their distance scales. The exceptions are lines 5 and 8 , which were conducted along the southwestern-most stretch of Rickett Point Road and South Beach Road, respectively. The distance scales of both lines are referenced from the intersection of the two roads. The distance scale for line 1-DP (Figure 10) is referenced from the southern limit of the TBP site.

Three shallow reflection profiles, lines 2, 3, and 4, were recorded perpendicular to Rickett Point Road across the TBP site. Line 4 also extends west of the road, north of the Prototype Building and PBW site, to the western shore of the Gunpowder Neck Peninsula. The distance scales for lines 2, 3, and 4 are referenced to the eastern limit of the TBP site.

Three shallow reflection profiles, lines 1,6 , and 7 , were recorded at the WPP site. Shallow line 1 was located along the same traverse as the deeper profile, line 1-DP. The distance scale for shallow line 1 is referenced to the southern boundary of the WPP site. Lines 6 and 7 


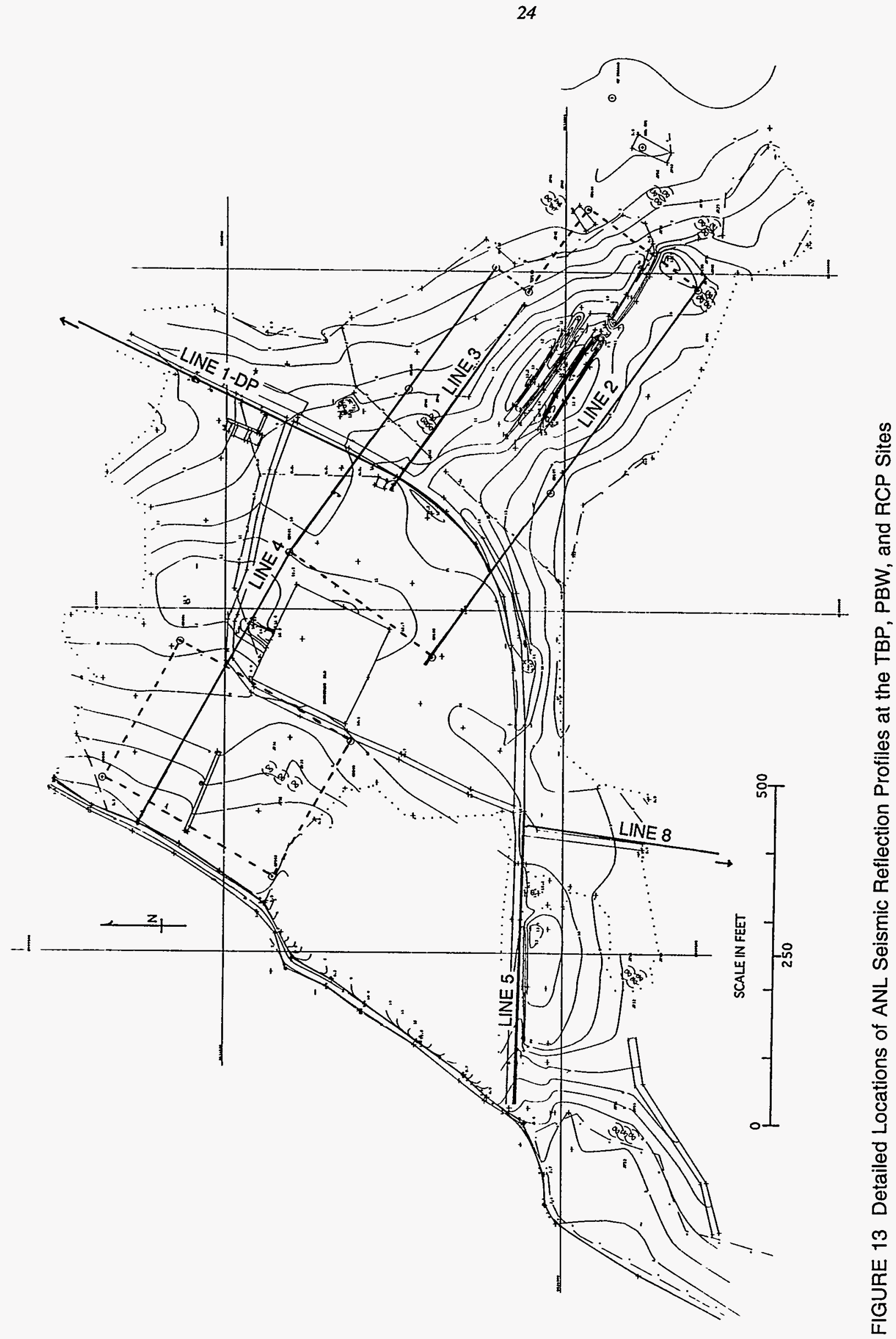




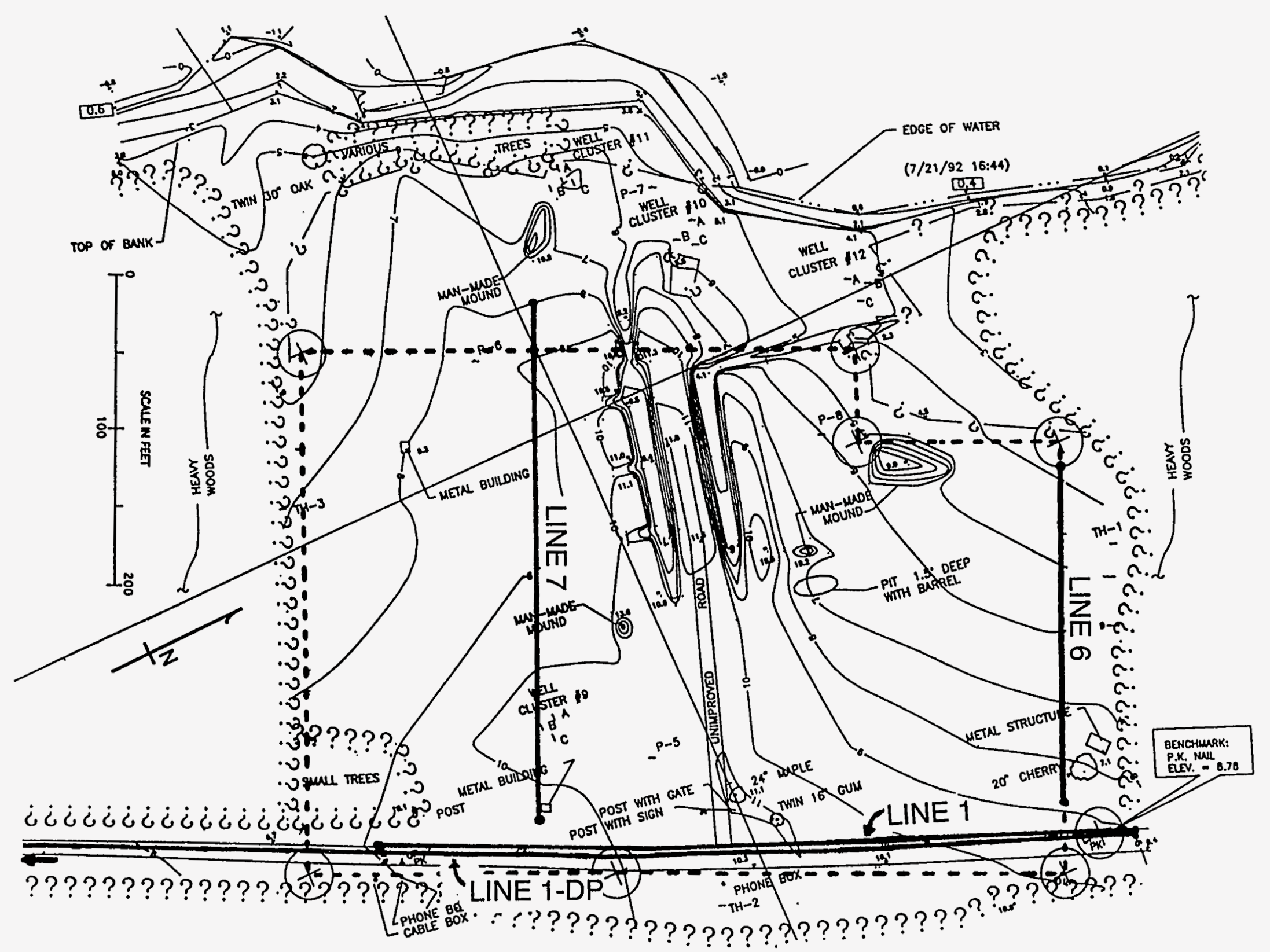

FIGURE 14 Detailed Locations of ANL Seismic Reflection Profiles at the WPP Site 
were oriented perpendicular to Rickett Point Road across the WPP site at northings of $490 \mathrm{~N}$ and $150 \mathrm{~N}$, respectively, according to the WPP grid. The distance scale for both lines is referenced from the western limit of the WPP geophysical survey area.

The seismic record section for deep line 1-DP is shown in Figure 15. The reflectors are generally flat, suggesting that the reflecting sedimentary rock units are continuous along a northsouth trend, which is roughly along the strike of the peninsula's axis. An interpretation of major sedimentary reflectors at the southern end of the profile is shown in Figure 15, bottom, and is discussed below.

Record sections for lines 2, 3, and 4 are shown in Figures 16, 17, and 18, respectively. Profiles 2 and 3 cross USGS well clusters 8 and 4, respectively, providing control for lithologic depths (well cluster 8 corresponds to wells JF81, JF82, and JF83; and well cluster 4 to wells $\mathrm{JF} 41, \mathrm{JF} 42$, and JF43 in Table 2). A prominent and continuous reflector at an average of about 30 milliseconds (ms) two-way time in each of the record sections corresponds to the top of Unit B of the Talbot Formation (Figures 16, 17, and 18), although the reflector becomes somewhat shallower in the eastern part of line 2 (Figure 16). The depth range of the reflector is generally between 25 and $45 \mathrm{ft}$. The reflector is also observed in deep line 1-DP (Figure 15, bottom), which crosses each of the shallow lines 2,3 , and 4 .

A more subtle but fairly continuous reflector is observed for the base of Unit B in lines 1-DP, 2, 3, and 4 (Figures 15 through 18, bottom, respectively). The reflector deepens to the east, as expected from well data, to nearly $50 \mathrm{~ms}$, or to a depth of about $115 \mathrm{ft}$. However, the reflector also shallows in the center of the TBP survey area, especially near $375 \mathrm{E}$ in line 2 (Figure 16, bottom), to about $30 \mathrm{~ms}$ or a depth of about $50 \mathrm{ft}$.

Record sections for lines 1, 6, and 7 in the WPPs area are shown in Figures 19, 20, and 21 , respectively. Profile 7 crosses USGS well cluster 9, providing control for lithologic depths (well cluster 9 corresponds to wells JF91, JF92, and JF93). The lithologic log for well cluster 9 is included in Hughes (1993). The reflectors in lines 1 and 7 are relatively flat except near $175 \mathrm{~N}$ in line 1 (Figure 19) and 150E in line 7 (Figure 21), where the reflectors shallow to the south and east, respectively. Line 6 (Figure 20) suffers from poor signal quality, probably caused by soft soil conditions, which can result in poor source-ground coupling.

Record sections for lines 8 and 5 in the southwestern corner of Gunpowder Neck Peninsula are shown in Figures 22 and 23, respectively. Both profiles show a similar transition of reflectors. The transition occurs at about $90 \mathrm{~W}$ in line 5 (Figure 23) and 190S in line 8 (Figure 22). At other distances, the data appear to be relatively unaffected by near surface (i.e., less than $30 \mathrm{ft}$ depth) velocity variations as indicated by nearly uniform first arrival times. Variable delays in the first arrivals in the vicinity of the transitions, which exceed $10 \mathrm{~ms}$ in Figure 23 , suggest that near-surface velocity variations may be more significant. The delays may be indicative of lithologic changes within Unit $C$. 


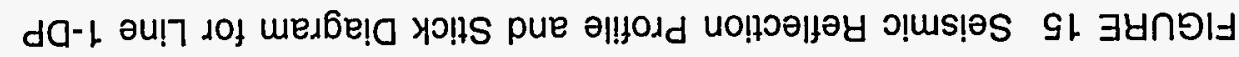
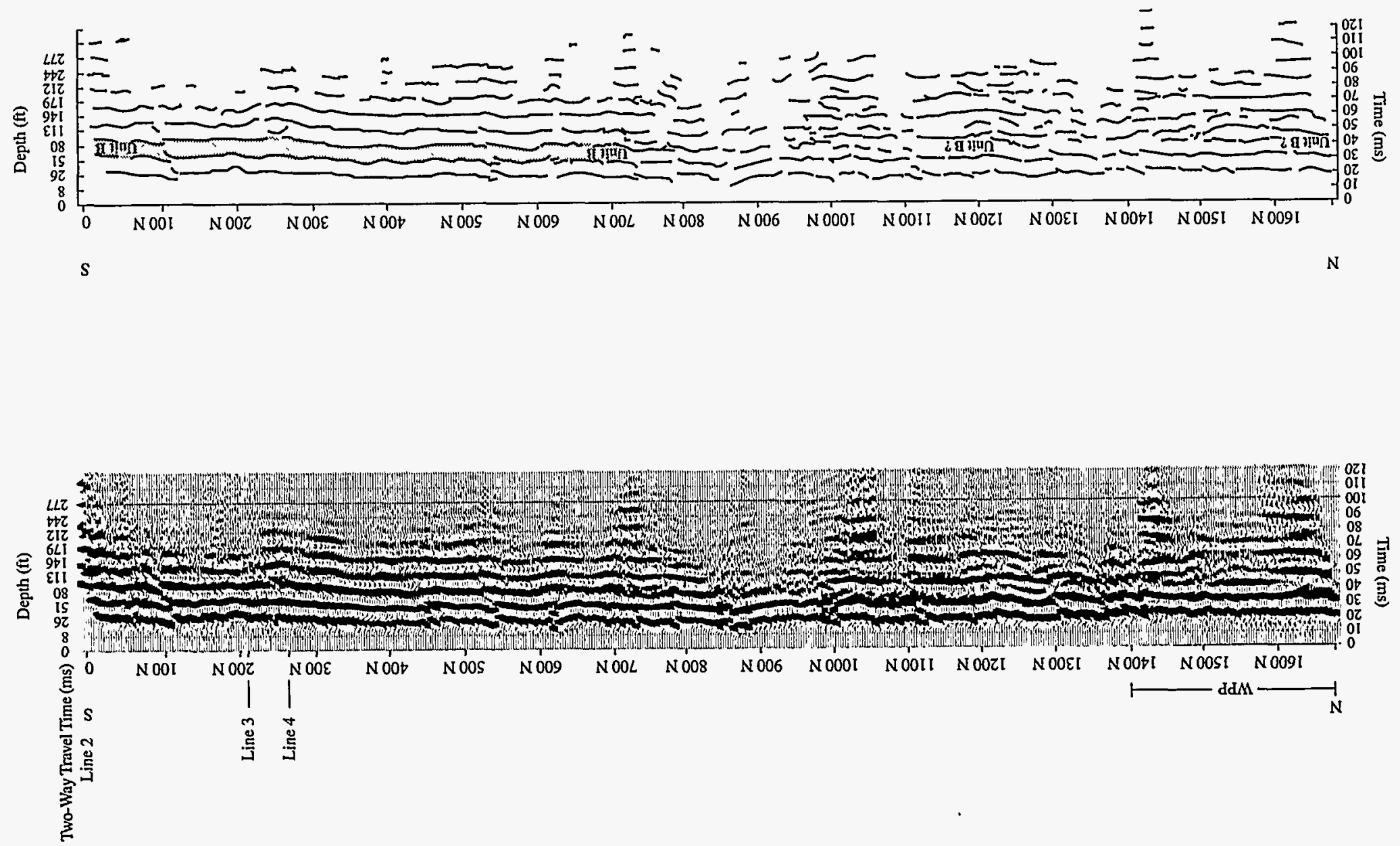


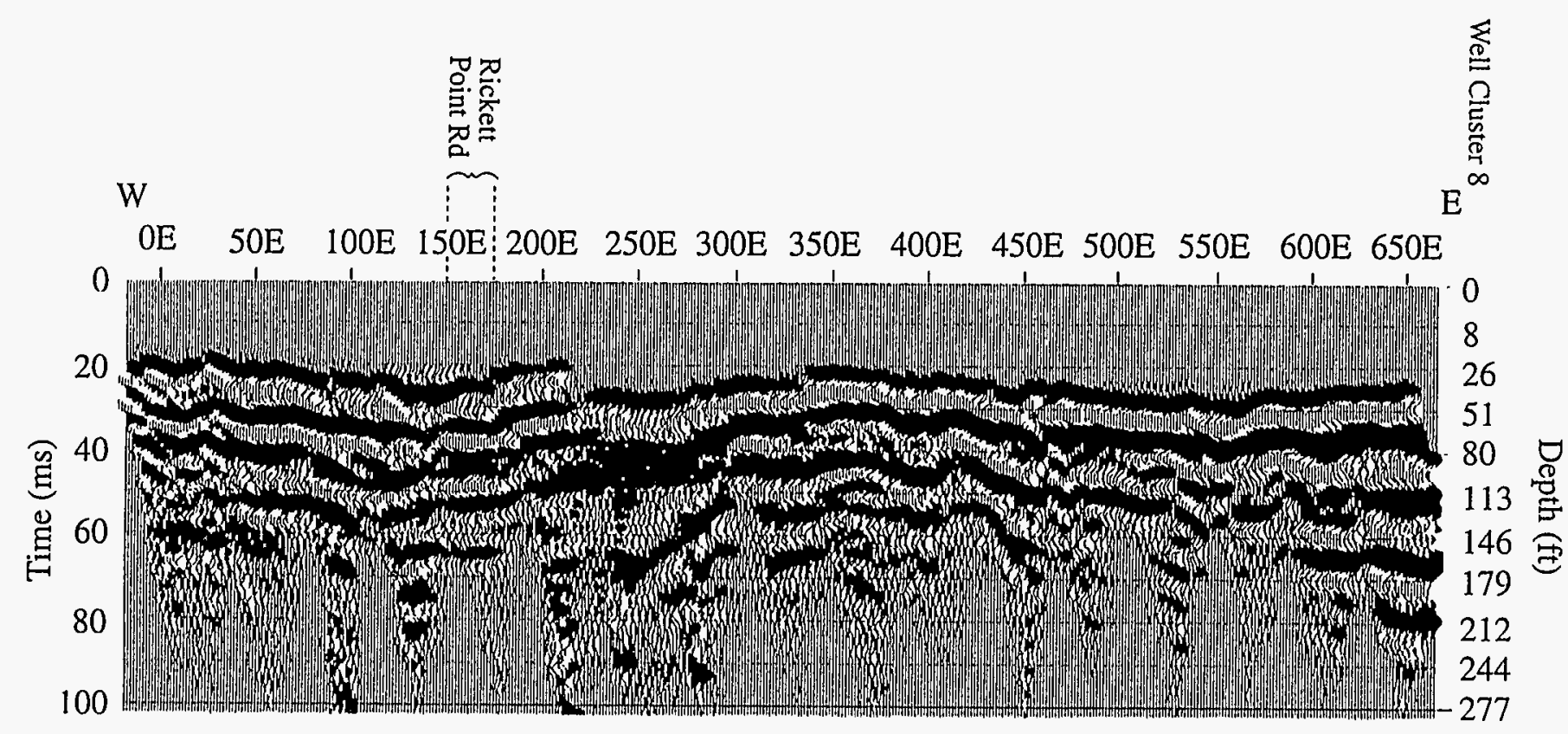

W

OW 50E 100E 150E 200E 250E $300 \mathrm{E} \quad 350 \mathrm{E}$ 400E $450 \mathrm{E}$ 500E $550 \mathrm{E} \quad 600 \mathrm{E} \quad 650 \mathrm{E}$

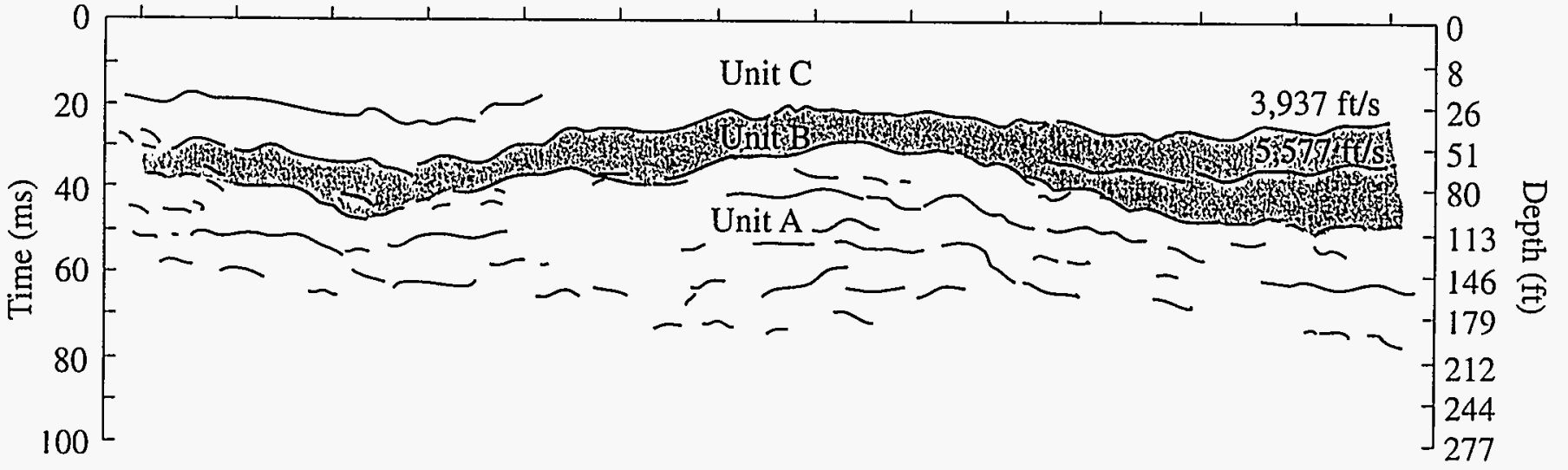

FIGURE 16 Seismic Reflection Profile and Stick Diagram for Line 2 

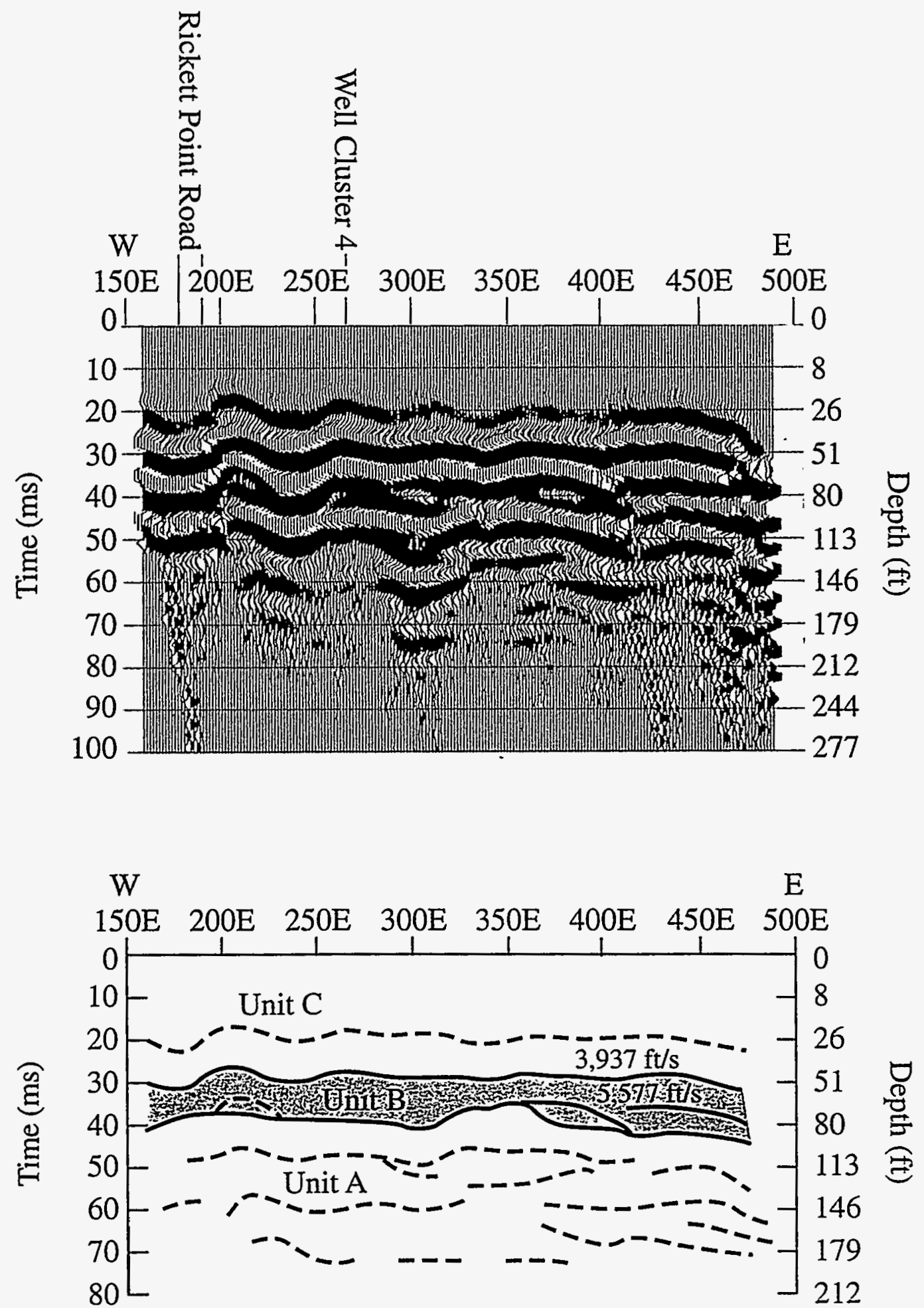

FIGURE 17 Seismic Reflection Profile and Stick Diagram for Line 3 


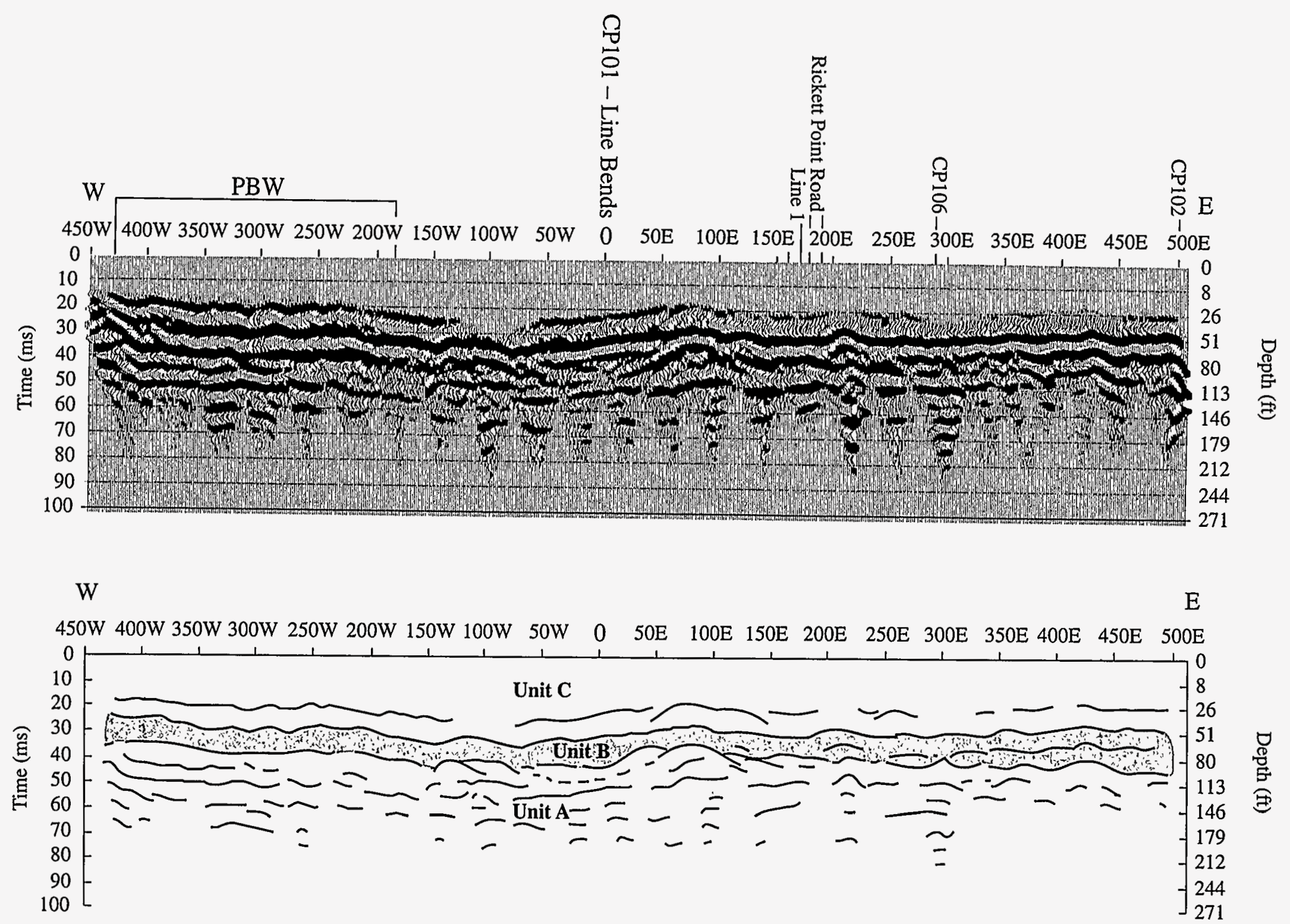

FIGURE 18 Seismic Reflection Profile and Stick Diagram for Line 4 


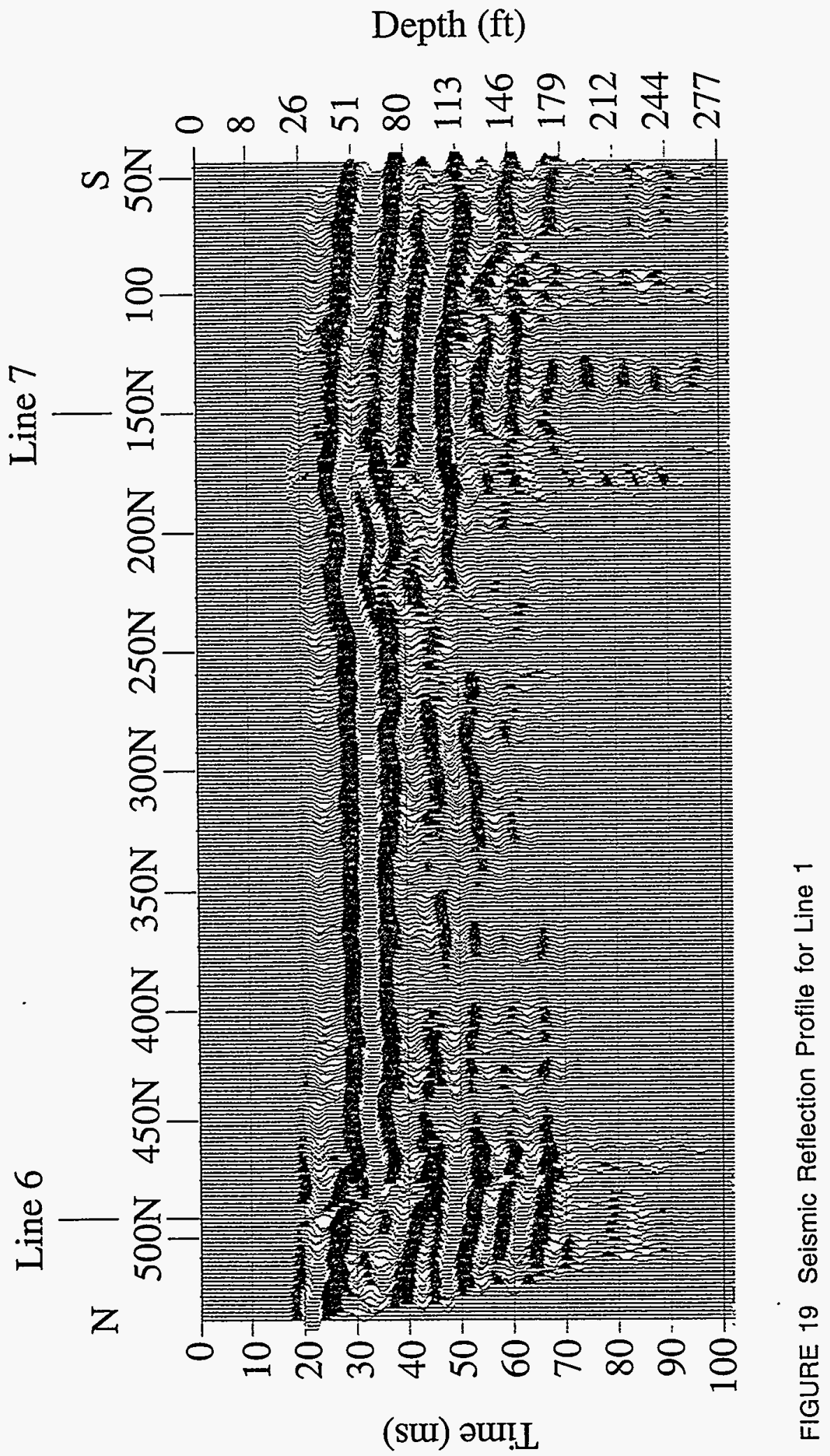




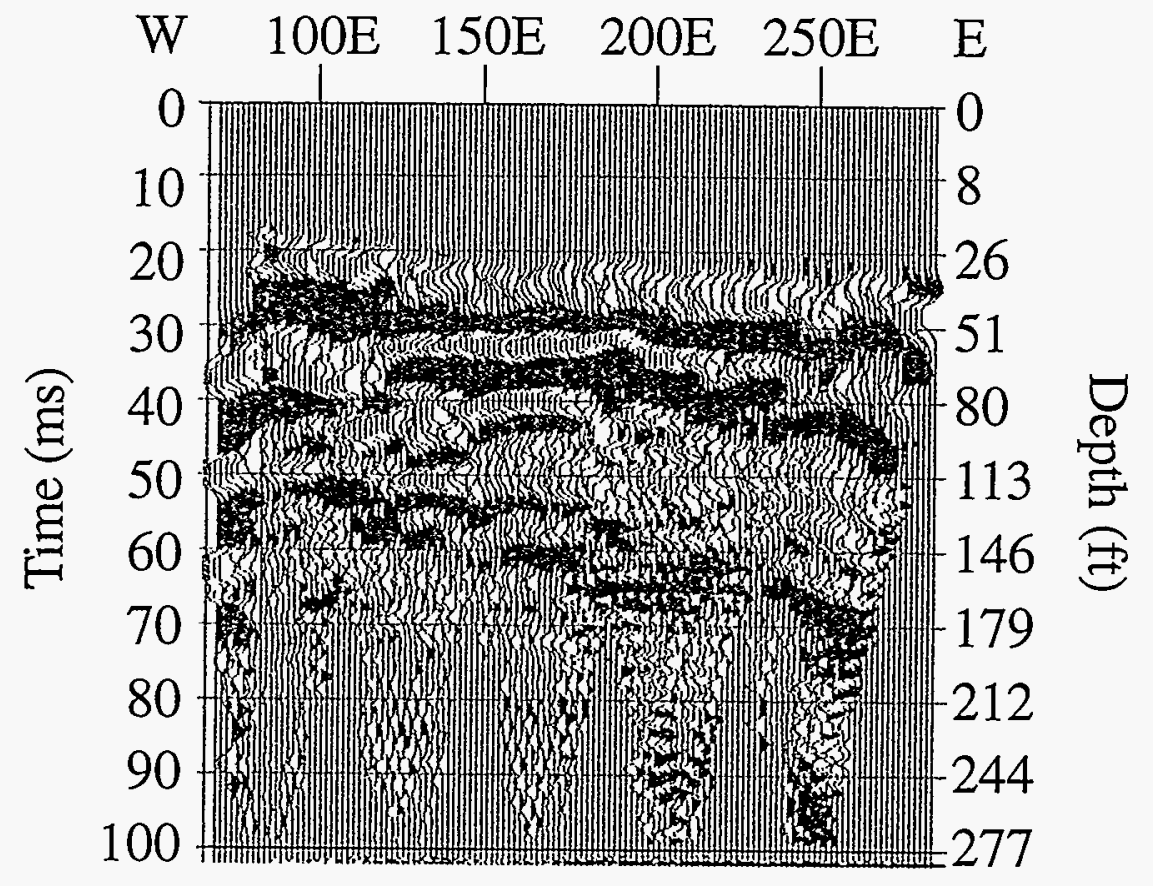

FIGURE 20 Seismic Reflection Profile for Line 6

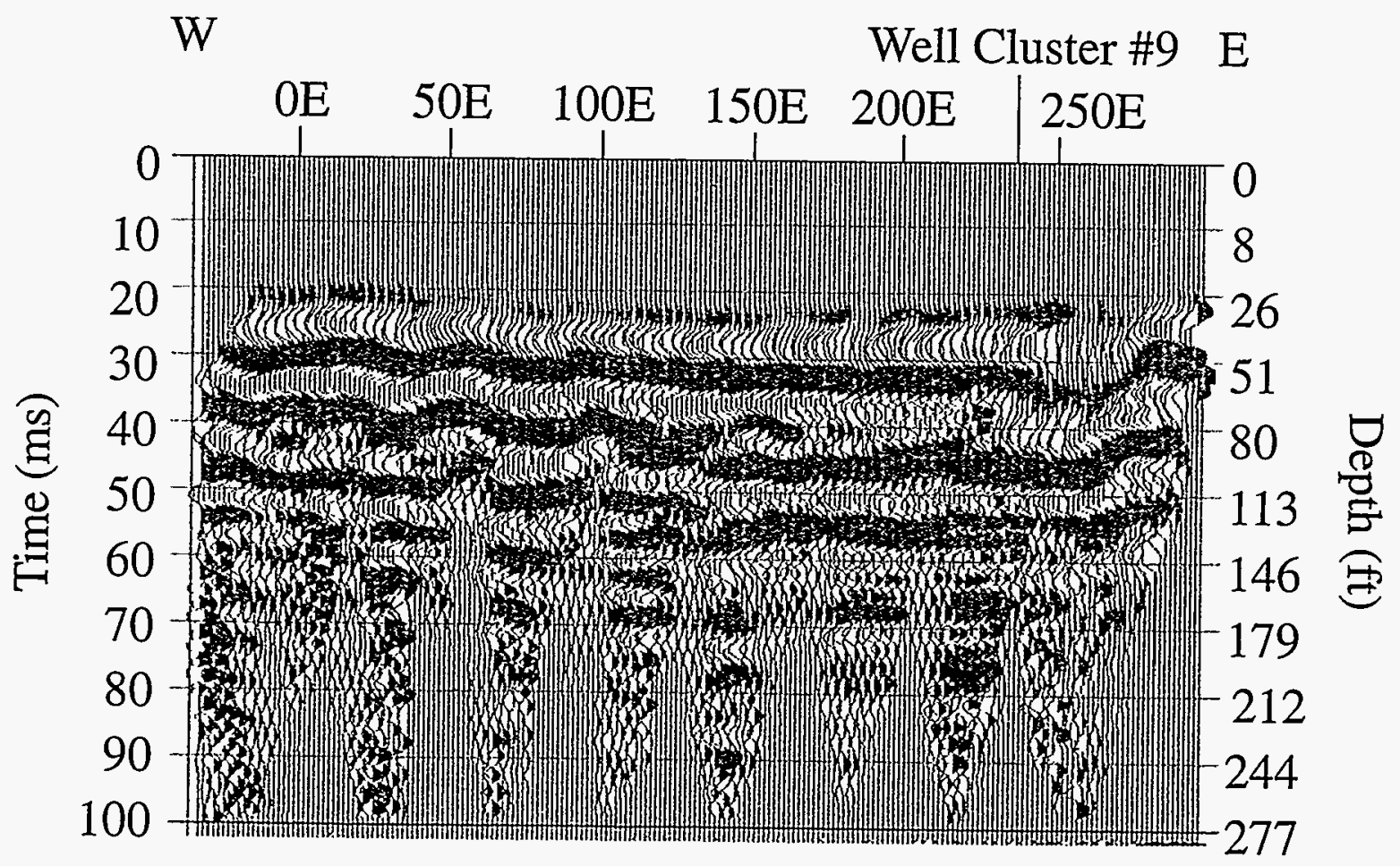

FIGURE 21 Seismic Reflection Profile for Line 7 


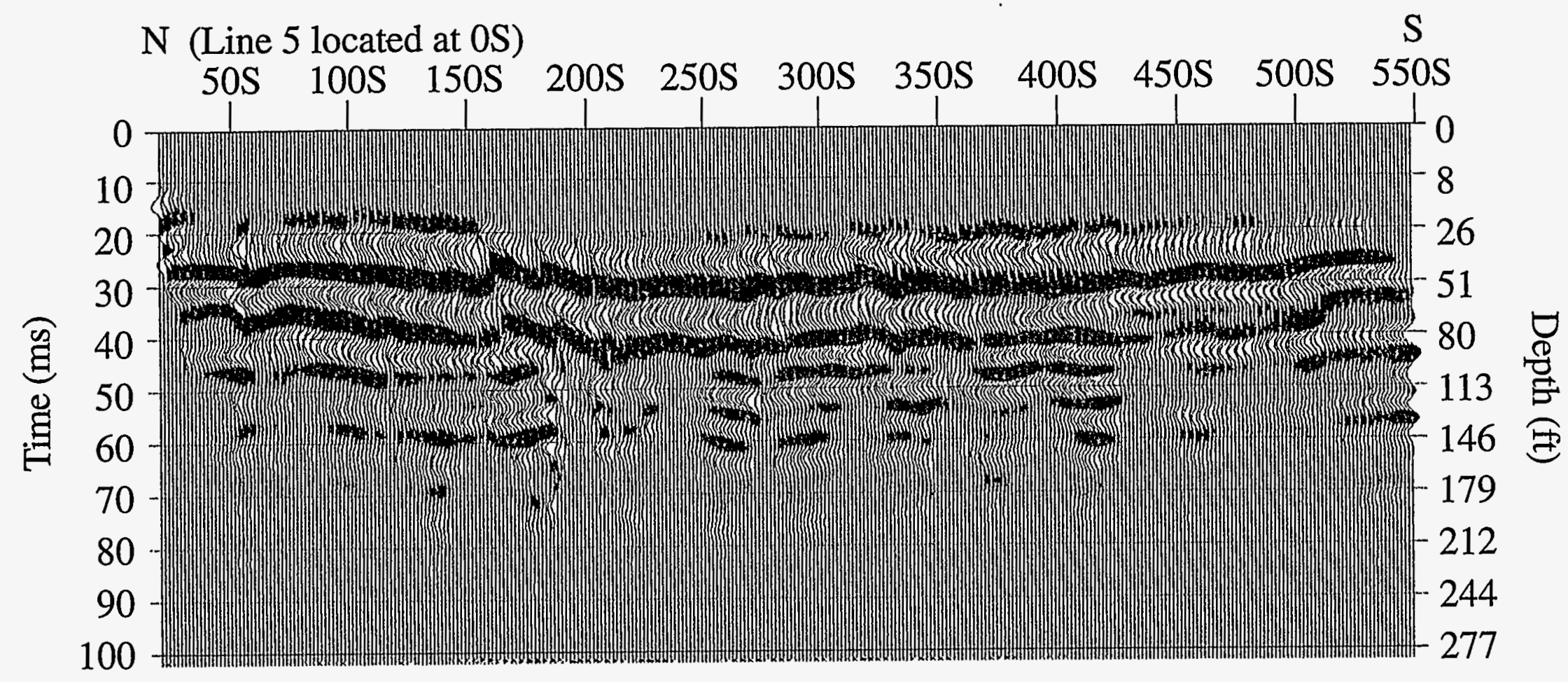

FIGURE 22 Seismic Reflection Profile for Line 8 


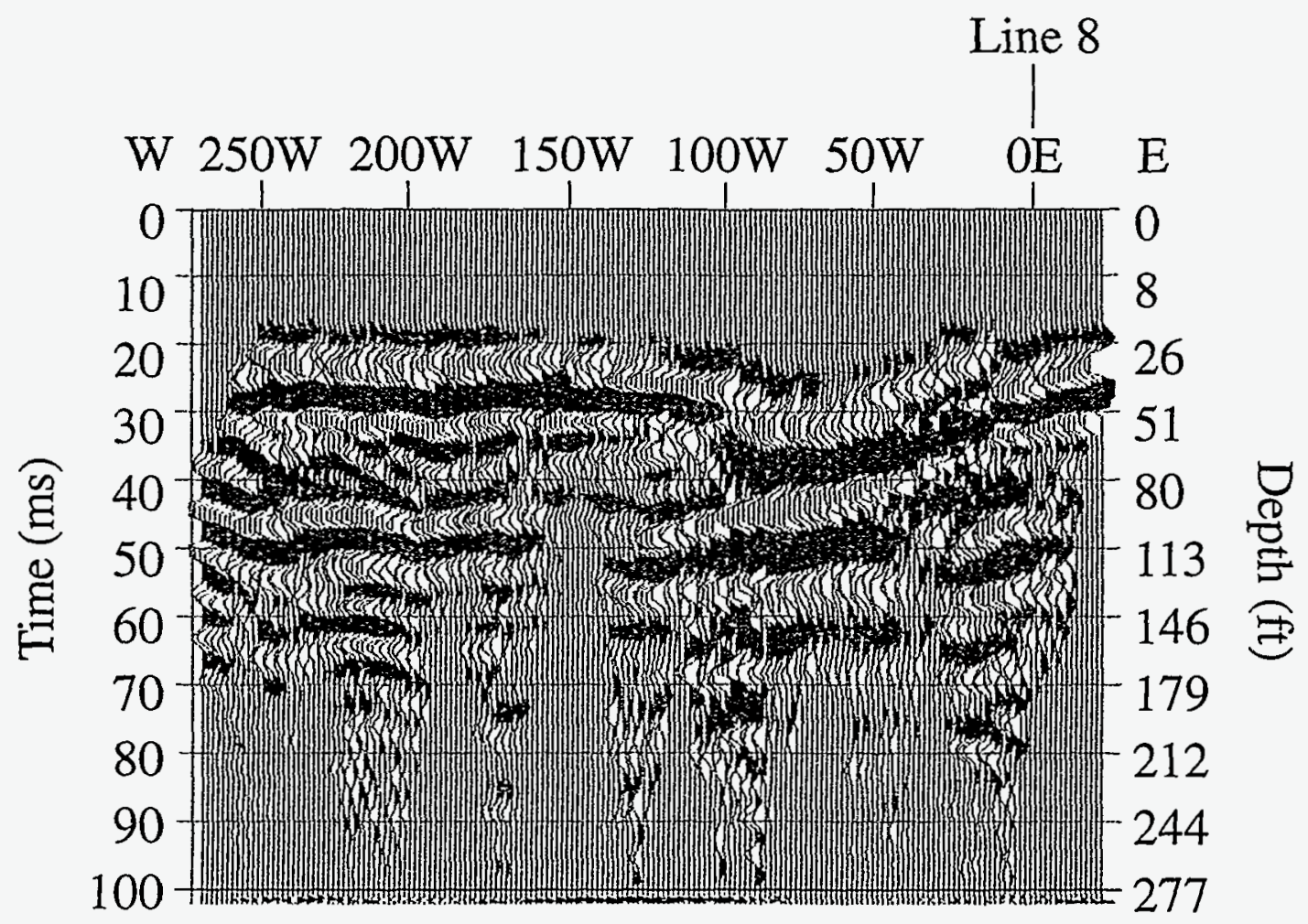

FIGURE 23 Seismic Reflection Profile for Line 5

A reflector corresponding to the contact between the Pleistocene Talbot Formation and the underlying Cretaceous Patapsco Formation or to variations within the Cretaceous sediments could not conclusively be identified in any of the reflection profiles. While reflections are observed to a depth of about $300 \mathrm{ft}$ in line 1-DP (Figure 15), velocity control from seismic refraction data and well data are currently limited to about $130 \mathrm{ft}$; therefore, associating deeper reflectors to a depth scale is unreliable. Deeper reflections from within the Patapsco are not readily identifiable.

\subsection{Electrical Resistivity Depth Soundings}

Electrical depth soundings using the ABEM Terrameter and the Bison/Boss electrode array, a modified Wenner configuration, were made at 10 sites at J-Field. Electrode separations at J-Field ranged from 1.6 to $210 \mathrm{ft}$. Locations of the centers of the soundings are shown in Figure 24 and listed in Table 7.

Resistivity curves (JF1-JF10) are shown in Figure 25 for all 10 sites with their interpreted resistivity vs. depth models. Resistivity data for a given profile do not yield an unique resistivity with depth, but rather a suite of equivalent models. Figure 25 shows equivalent resistivity vs. depth models for each sounding. The equivalent models graphically illustrate the inherent limitation 


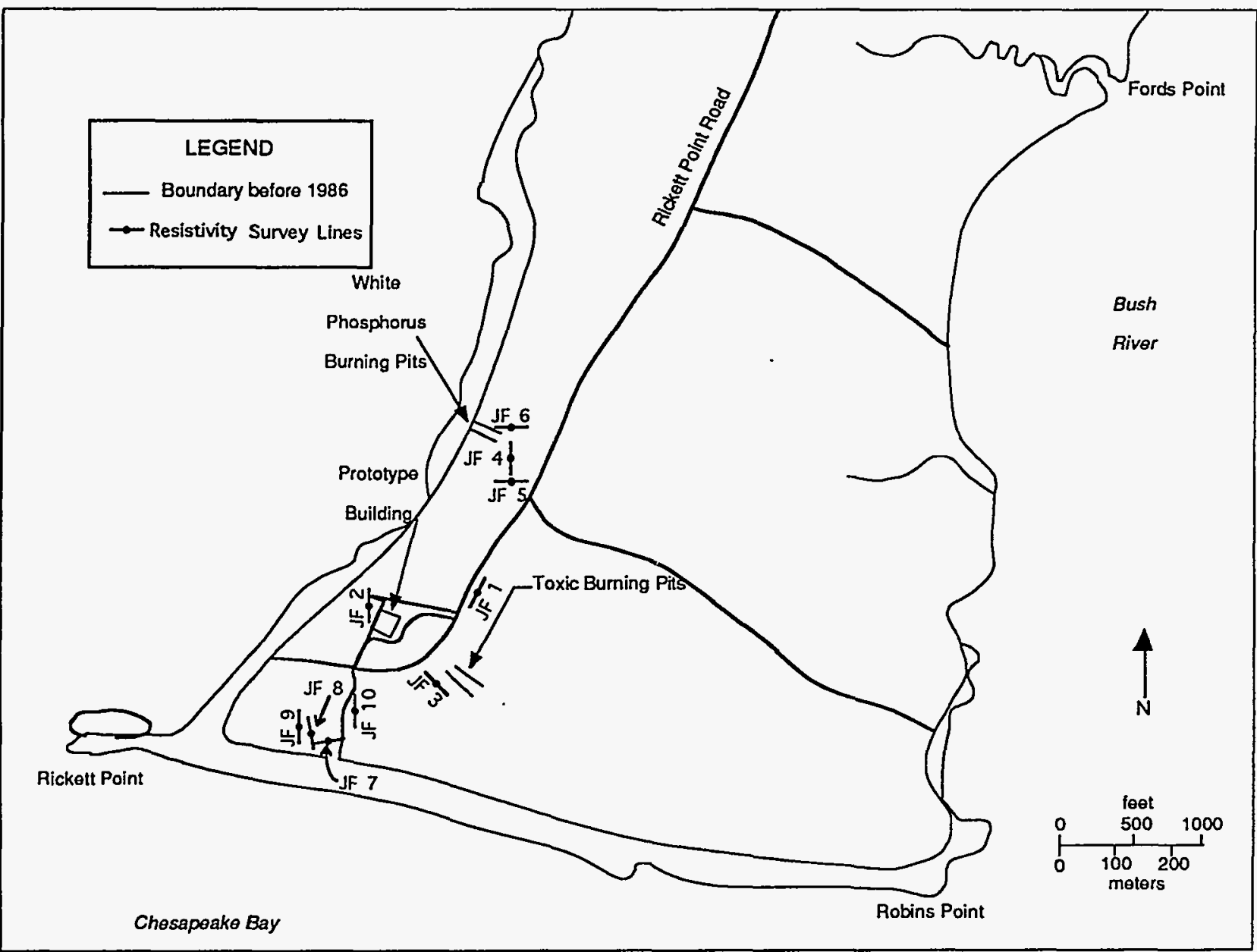

FIGURE 24 Locations of Electrical Resistivity Depth Soundings (Source: Adapted from Hughes 1991)

TABLE 7 Electrical Resistivity Depth Sounding Parameters

Maximum Electrod

Spacing $(m)$

Location Description

JF1 $\quad 64$

JF2 32

JF3 64

JF4 64

JF5 32

JF6 32

JF7 32

JF8 16

JF9 16

JF10 32
Rickett Point Road, center $96 \mathrm{~m}$ north of the TBP N-line

PBW oriented N-S, center 150-200E

TBP oriented E-W, center ON-335E

WPP oriented N-S, center $200 \mathrm{~N}-200 \mathrm{E}$

WPP oriented E-W, center 200E-ON

WPP oriented E-W, center $490 \mathrm{~N}-200 \mathrm{E}$

RCP oriented E-W, center $124 \mathrm{ft} E$ of well cluster 1

RCP oriented N-S, center USGS well cluster 1

RCP oriented E-W, center $128 \mathrm{ft} W$ of well cluster 1

South Beach Road, center $350 \mathrm{ft} \mathrm{S}$ of Rickett Point Road 

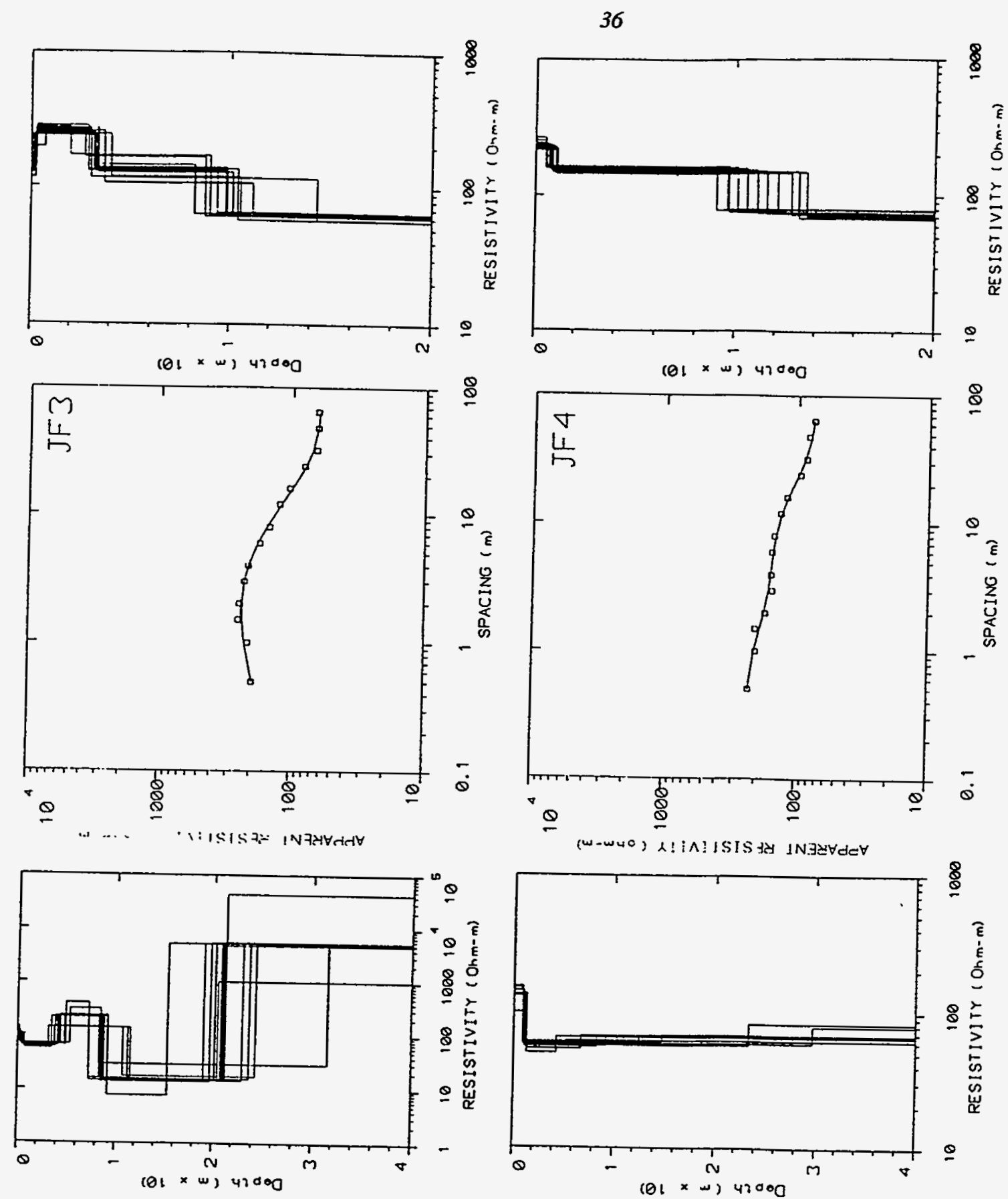

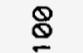
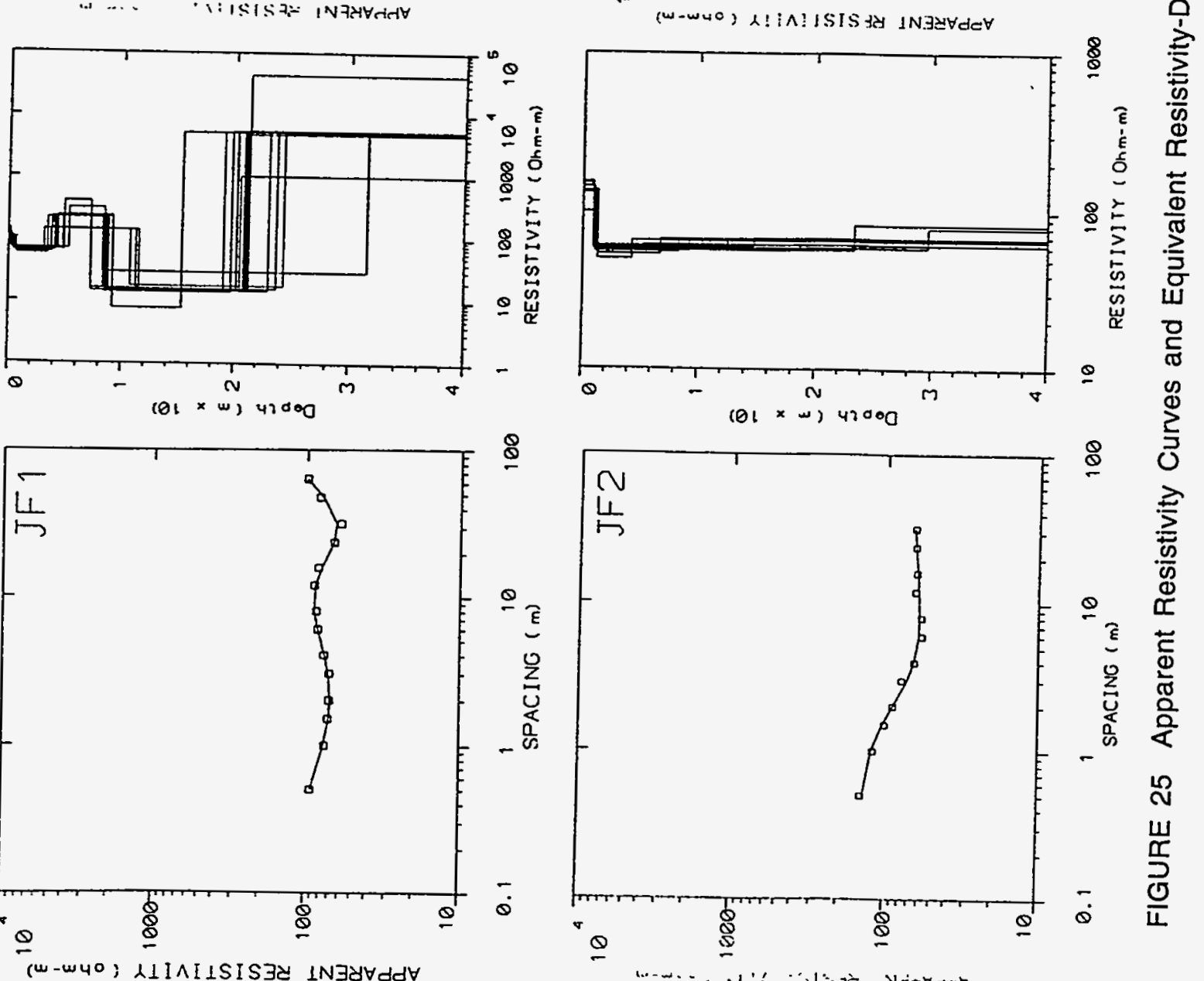

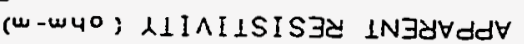



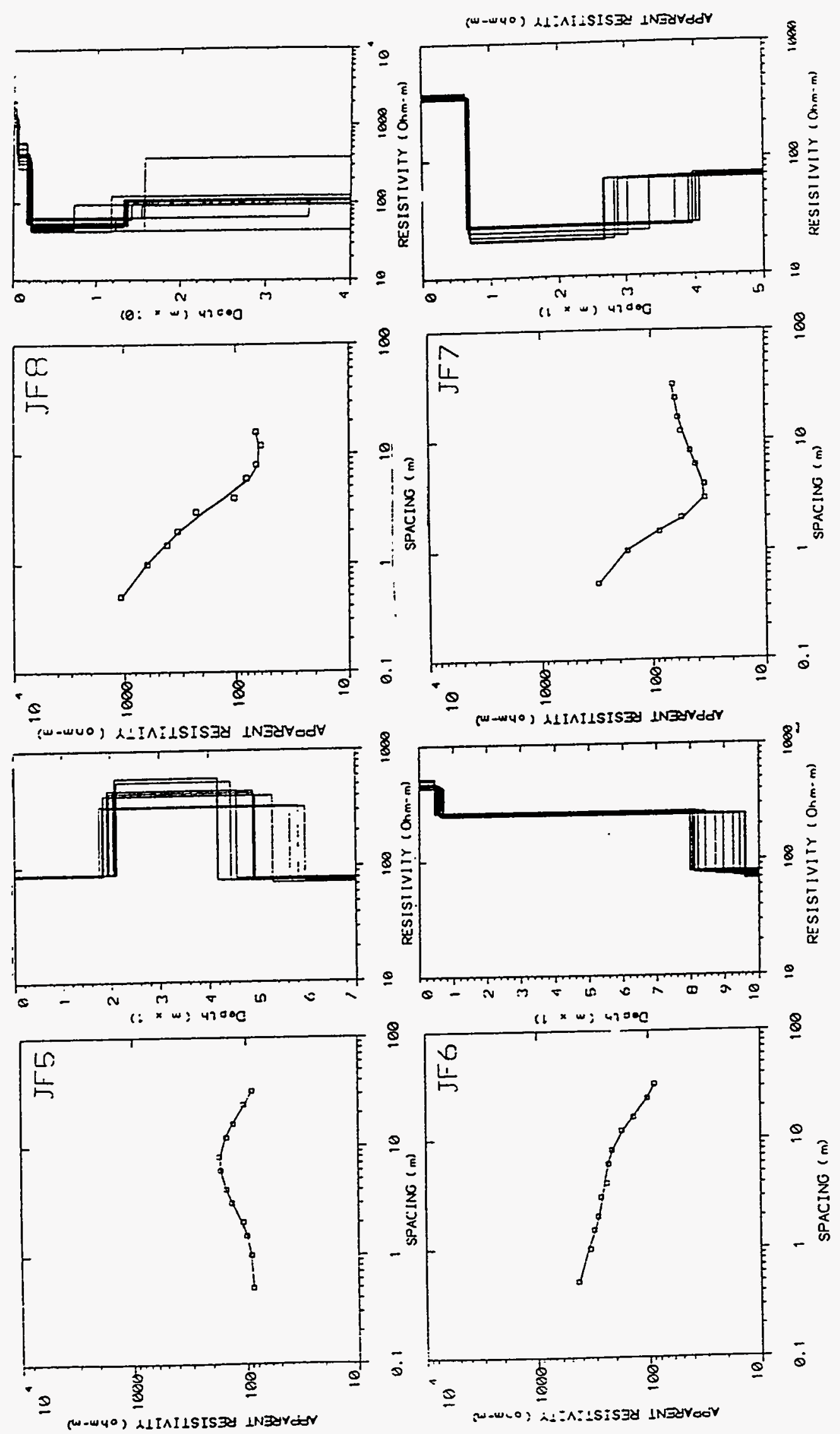

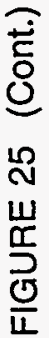



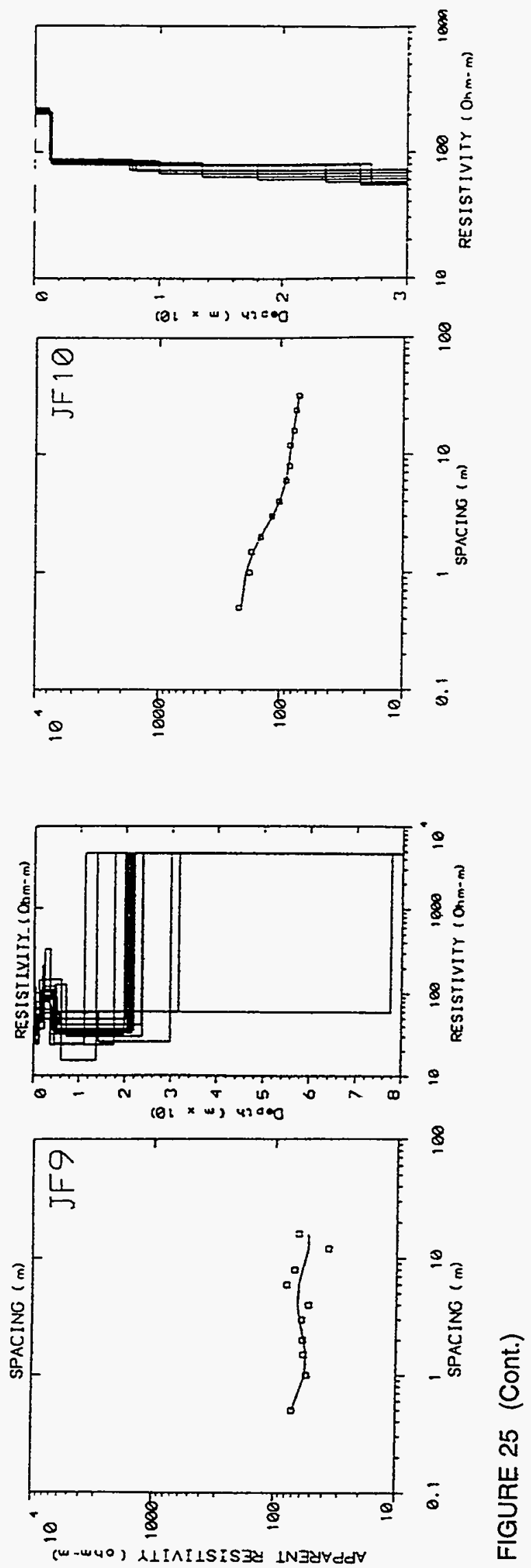
of the resistivity method; i.e., depths and resistivities interpreted from resistivity sounding data have limited resolution and are best used in the observation of trends and consistency checks with other geophysical data. The resistivity data provide approximate depths to the water table, and they also provide a useful comparison with seismic data.

Resistivities at J-Field range from approximately $20 \Omega \cdot \mathrm{m}$ to several hundred $\Omega \cdot \mathrm{m}$. Most of the sites provided limited access for electrode array expansion, thus maximum e-spacing was $64 \mathrm{~m}$. All except two of the profiles in Figure 25 show a decrease in resistivity with depth within several feet of the surface, mostly at depths of $2-4 \mathrm{ft}$. The decrease in resistivity corresponds to the depth at which sediments become saturated.

Subsequent changes in resistivity with depth are likely indicators of the relative clay (low resistivity) or sand (high resistivity) content. Over half of the J-Field resistivity profiles indicate a decrease in resistivity at depths below the water table, indicating a likely increase in clay content. Profiles JF1 and JF3 in the vicinity of TBP, profiles JF4 and JF6 at WPP, and JF10 in the South Beach area indicate the depth range at which the decrease in resistivity occurs is approximately $30-36 \mathrm{ft}$, likely corresponding to the transition from Unit C, which is relatively sandy, to Unit B, which is predominantly clay.

Two profiles, JF1 near TBP and JF9 at RCP, show substantial increases in resistivity at a depth of approximately $70 \mathrm{ft}$. Profile JF9 may be somewhat unreliable at this depth due to the relatively short maximum electrode spacing and the scatter in apparent resistivity values. However, profile JF1, with somewhat similar apparent resistivity curves, was recorded with a relatively long maximum electrode spacing, shows relatively little scatter, and probably provides the greatest depth of penetration for the J-Field profiles. This electrical boundary in either or both profiles may represent the transition from Unit B to the underlying Unit A, which has a relatively low clay content.

\subsection{Electrical Conductivity}

Conductivity measurements were made with the Geonics EM-31, an electromagnetic instrument that provides mean values of apparent conductivity for materials ranging from 0 to $20 \mathrm{ft}$ in depth. Data were collected along 10-ft transects at the TBP, WPP, PBW, and RCP sites; and along 5-ft transects at the JF133 site. Additionally, single profiles were conducted at three locations in the south beach area. The areas and profiles south of Rickett Point Road were surveyed in order to gain insight on shallow hydrogeological characteristics and on the range of conductivities to be expected under conditions less disturbed than TBP and WPP sites. The profiles in particular provide regional control on electrical characteristics, both natural and anthropogenic, to be expected in the J-Field region.

Old EM surveys were not compared with present surveys because the degree of saturation of soils and changes in elevation of the water table make it highly unlikely that electrical conditions in the near surface, over a long period of time, would remain static. From the time of initial 
writing of the objectives, it was decided to use an EM-31 for the conductivity survey because of the far greater efficiency and ground coverage potential with the EM-31 relative to the EM-34, which was used by the USGS. Therefore, conductivity comparisons could not be made from that aspect as well.

Data were acquired on a digital data logger at a 0.5 -s sampling rate in all areas except along the south shore profile, where the rate was $1.0 \mathrm{~s}$. Converting data acquisition rates to distance traveled results in a mean station spacing for all areas surveyed of $1.5 \mathrm{ft}$, except for the south shore profile - which was $3 \mathrm{ft}$. Data acquisition parameters are shown in Table 8 . Conductivities for all sites range from approximately 5 to 130 millisiemens per meter $(\mathrm{mS} / \mathrm{m})$, with the greatest range being observed along the shoreline from Rickett Point Road to approximately 1,000 ft north of South Beach Road.

\subsubsection{Toxic Burning Pits Site}

Conductivity values at the TBP site are shown in Figure 26. They are represented as contours over a total intensity magnetic field color map in Figure 26A and as a color map overlaid by magnetic contours in Figure 26B. (Magnetic data are discussed in Subsection 3.6.)

TABLE 8 Electrical Conductivity Parameters Using the EM-31

\begin{tabular}{lccl}
\hline \multicolumn{1}{c}{ Site } & No. of Observations & Area $\left(\mathrm{ft}^{2}\right)$ & Survey Dimensions \\
\hline TBP & 7,061 & 174,200 & $0-260 \mathrm{~N} \times 0-670 \mathrm{E}$ \\
WPP & 7,784 & 161,700 & $0-490 \mathrm{~N} \times 0-330 \mathrm{E}$ \\
PBW & 3,996 & 66,700 & $0-290 \mathrm{~N} \times 0-230 \mathrm{E}$ \\
JF133 & 1,054 & 7,500 & $0-50 \mathrm{~N} \times 0-150 \mathrm{E}$ \\
RCP & 1,648 & 28,000 & $0-175 \mathrm{~N} \times 0-160 \mathrm{E}$ \\
S. Beach Rd. & 180 &.-- & $500 \mathrm{ft}, \mathrm{N}$ to $\mathrm{S}$ \\
RCP Ext & 200 &.- & $750 \mathrm{ft}, \mathrm{W}$ to $\mathrm{E}$ \\
S. shorec & 739 & $-\cdots$ & $2,400 \mathrm{ft}, \mathrm{W}$ to $\mathrm{E}$ \\
& & & \\
Totals & 22,662 & 438,000 & \\
\end{tabular}

a A single profile south along South Beach Road starting from Rickett Point Road.

b A single profile from the south end of Rickett Point Road (at the western shore) east across RCP to South Beach Road.

c A single profile southeast along the south shore starting from Rickett Point Road. 

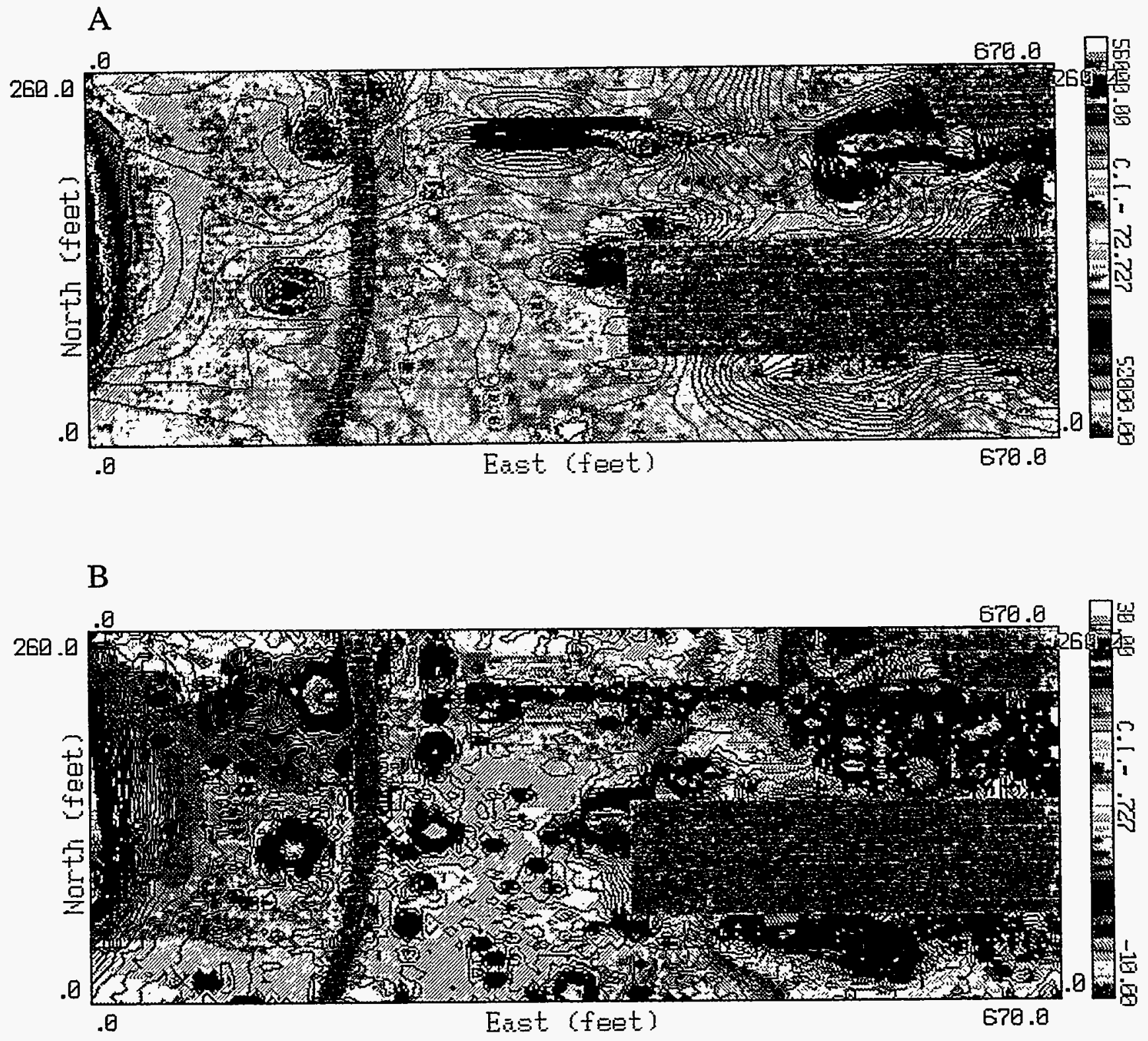

FIGURE 26 EM-31 Electromagnetic and Total-Field Magnetic Data for TBP Site. A: Magnetic Color Map with Electrical Conductivity Contours. B: Electrical Conductivity Color Map with Magnetic Contours. 
High conductivities in the eastern third of the surveyed area are partly caused by conductive debris in the "push-out" areas, where refuse from the burn pits and surrounding vicinity has been pushed aside with heavy machinery. High values are also partially caused by increased saturation of the soils due to decreasing elevation in the east. Plume-like trends in conductivity values are more reflective of topography than they are of contaminants.

An east-west conductive lineament bounded by minima in the north-central TBP site is the product of a trench, probably the buried liquid smoke disposal pit. Chemicals associated with this material include titanium tetrachloride, sulfur trioxide, and chlorosulfonic acid, which, if dissolved in water, would produce conductivities above background. A conductivity minimum south of the

north-central anomaly is produced by a westward extension of the TBP trenches. The presence of a minimum at the western pit extension suggests that relatively clean fill was used to fill the pit. Circular conductivity anomalies adjacent to Rickett Point Road are produced by buildings and surficial waste metals. Positive anomalies in the far west section of the TBP site are caused by proximity to tine Protoiype Building.

Regional, low-gradient trends in conductivity are reflective of topography and depth to the zone of saturation. A broad central minimum is flanked to the east and west by gradually increasing values. The minimum is generally located along the crown of Gunpowder Neck Peninsula, with drainage systems and wetlands being located to the east and west.

\subsubsection{White Phosphorous Burning Pits Site}

Conductivities at the WPP site are shown in the color map in Figure 27A, overlain with contours of the total intensity magnetic field. The magnetic information, also shown as a color map in Figure 27B, is discussed in Subsection 3.6. Regional conductivities at the WPP site, in an area measuring $330 \mathrm{ft} \mathrm{E}-\mathrm{W}$, and $490 \mathrm{ft} \mathrm{N}-\mathrm{S}$, are broadly reflective of topography. A broad, north-south oriented minimum, widening to the north, parallels the western edge of the road. The minimum represents the high axis of the peninsula upon which the road was built. Regional trends are abruptly terminated to the east of the WPP survey area in the proximity of Rickett Point Road and in the central part of the survey area on the east side of the pits. The road bed traversing the WPP site is composed of crushed gravel composed of amphibolite, similar to that found in many other areas of APG. The positive anomaly east of the pits is associated with a hill of conductive waste pushed out of the pits during pit clearing operations. In the west and southwest sections of the survey area, conductivities generally increase along a regional trend. A well-defined circular, positive anomaly in the southwest corner is associated with a small building. Small amplitude anomalies are scattered throughout the site. 


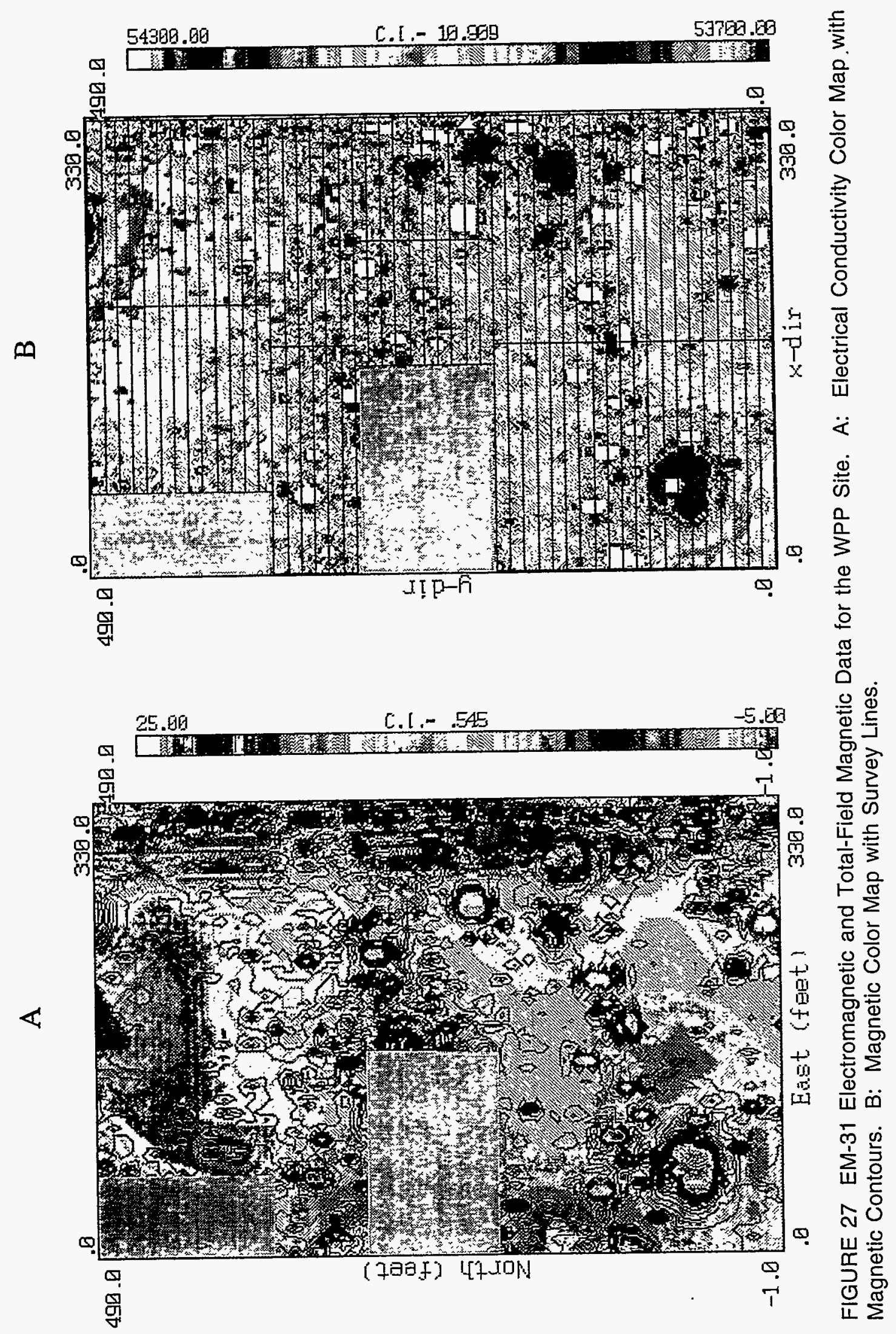




\subsubsection{West Side of Prototype Building Site}

Conductivities at the PBW site are represented as contours over a total intensity magnetic field color map in Figure 28A, and vice versa (a color map overlain by magnetic contours) in Figure 28B. The magnetic information is discussed in the section for magnetics, Subsection 3.6.

Unlike the TBP and WPP sites, there is no historical record of trenching activity at the PBW site. The most prominent conductive feature at the site is the building-generated anomaly on the east side, shown in Figure 28. A high-conductivity nose extends northwest from the building, and a less prominent conductive feature extends west from the southeastern corner of the surveyed area. The southern anomaly appears to be linked to a conductive substance down-slope from USGS well cluster 3 (wells JF31, JF32, and JF33). The source of the anomaly is unknown. The three wells are identified by the three localized magnetic anomalies centered at grid coordinate $130 \mathrm{E}, 60 \mathrm{~N}$.

\subsubsection{South Beach Road Profile}

Conductivities along South Beach Road extending south from the intersection of Rickett Point Road (Figure 29) show an excellent display of natural background conductivities in the J-Field area. Conductivities gradually decrease from north to south, reaching a minimum value of $5 \mathrm{mS} / \mathrm{m}$ at the $5-\mathrm{ft}$ erosional escarpment adjacent to the beach, before rising to $50 \mathrm{mS} / \mathrm{m}$ on the beach itself, then increasing by a factor of 10 within $100 \mathrm{ft}$ of the escarpment (Figure 29). The decline near the escarpment might be linked to changes in soil type and mineralogy. However, it is more likely due to a drop in elevation of the water table and to a capillary fringe proximal to the escarpment where the water table descends to sea level. The abrupt rise in conductivity on the beach below the escarpment is the result of sediments reaching $100 \%$ saturation with an increase in total dissolved solids in the groundwater, which is subject to tidal fluctuations.

\subsubsection{Profile Extending across Riot Control Pit Site}

A profile was conducted across the RCP site starting from the south end of Rickett Point Road at the western shore and ending at South Beach Road at a point $135 \mathrm{ft}$ north of the South Beach escarpment (Figure 30). The profile provides a good example of anthropogenic impact on natural conductivities. High conductivities to the west reflect the combined influence of increased saturation and the presence of crystalline rock used in beach reinforcement by the U.S. Army Corps of Engineers. Metallic debris in the area of the RCP may also contribute to the large positive anomaly filling the western half of the profile. At approximately $420 \mathrm{ft}$, a short-wavelength, positive anomaly is caused by steel casing in a monitoring well. Longer-wavelength, positive anomalies to the east are associated with anthropogenic materials in the South Beach trench area. Minimum values in the range of $10 \mathrm{mS} / \mathrm{m}$ reflect normal background. 


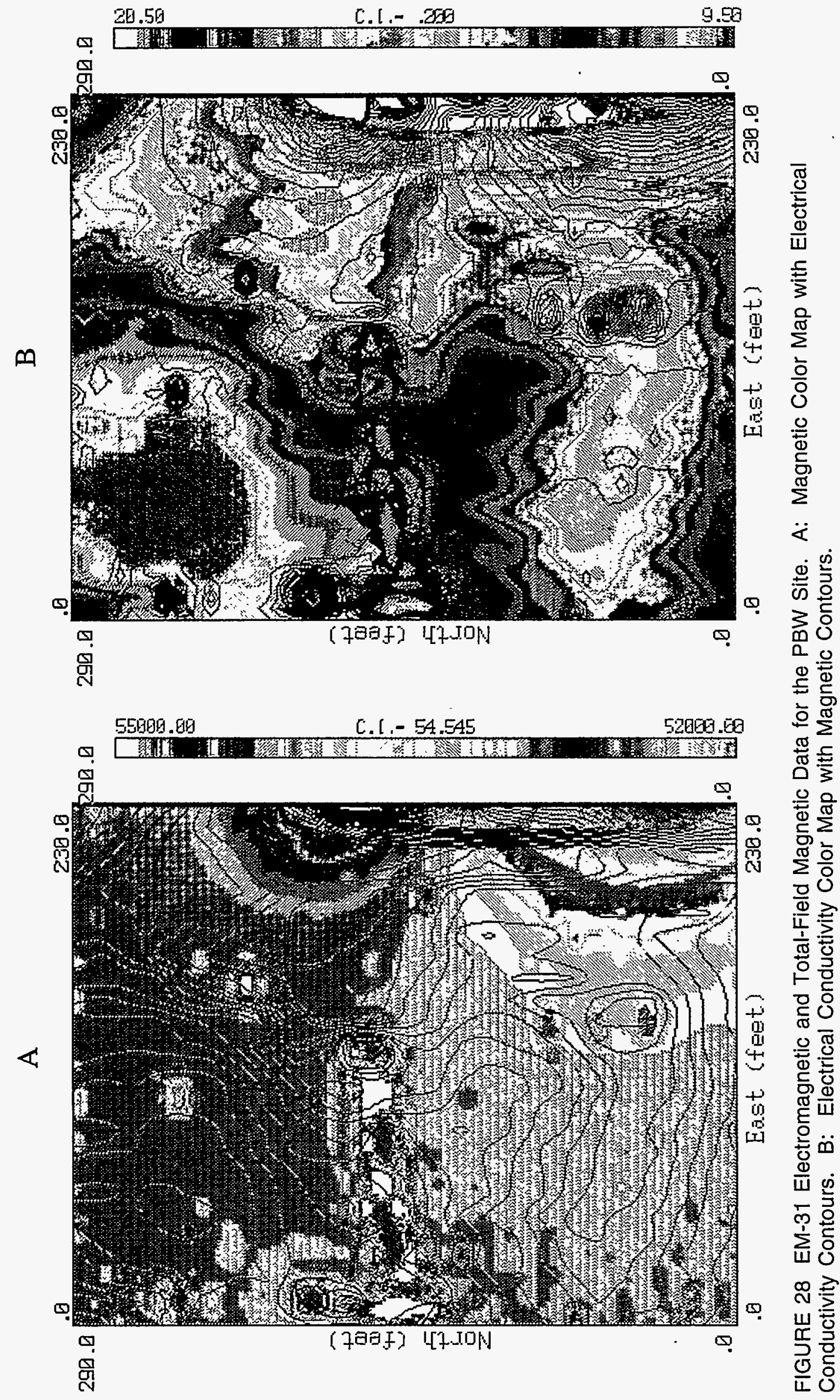




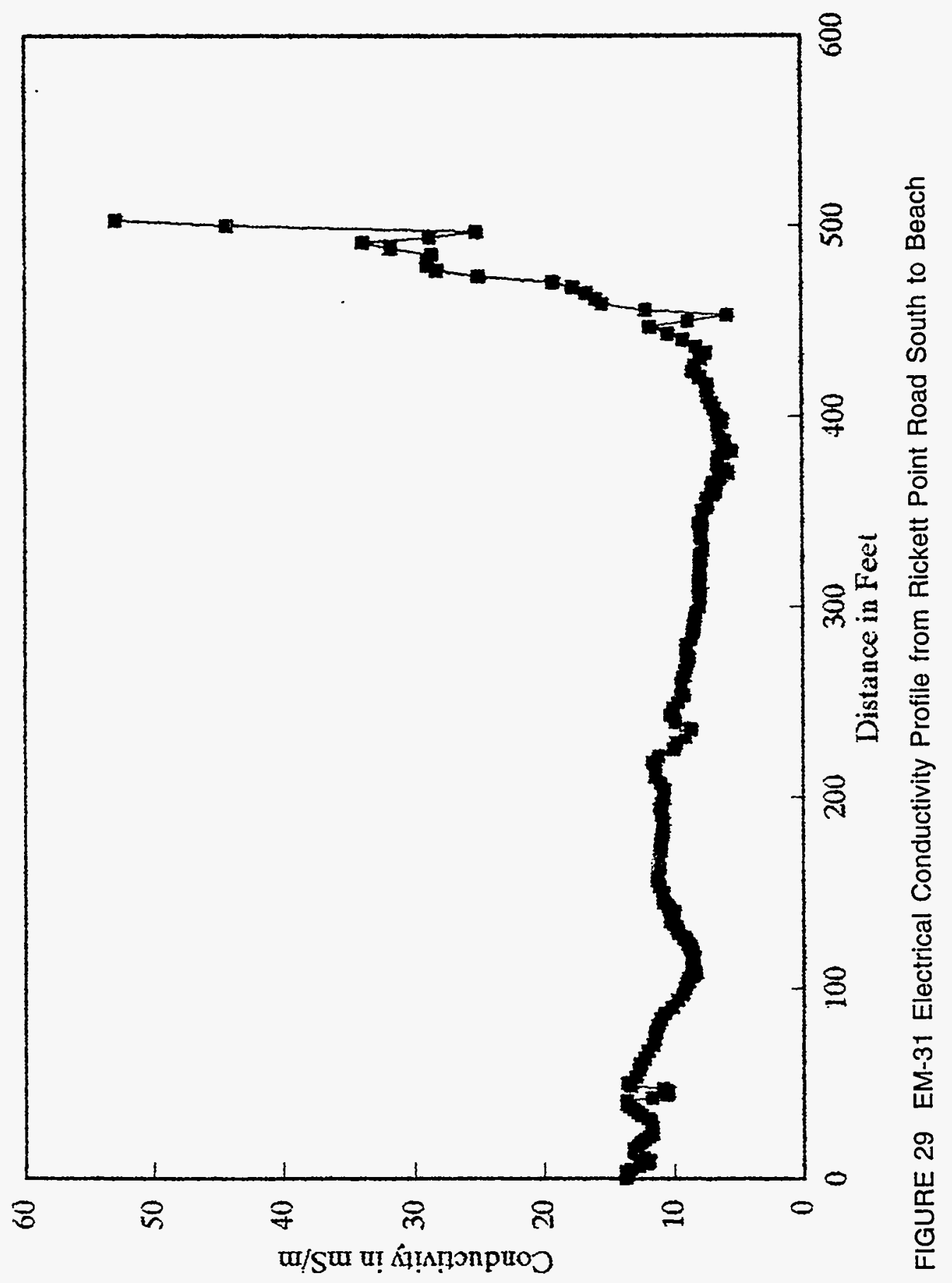




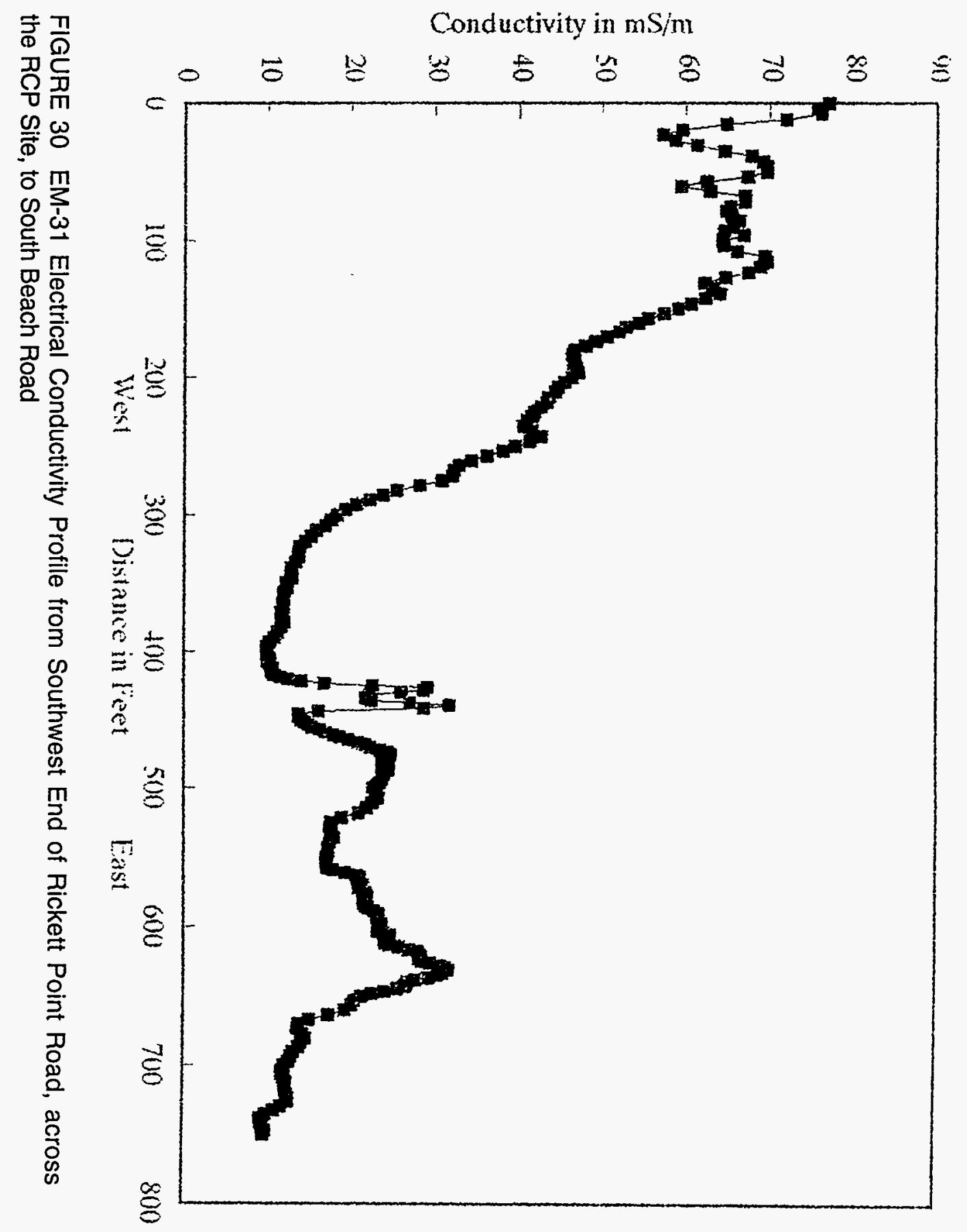




\subsubsection{Profile along the South Shore of Gunpowder Neck Peninsula}

The south-shore profile was conducted along the shore of Gunpowder Neck Peninsula, starting from the southern end of Rickett Point Road (at the western shore), running south to the southwestern tip of Gunpowder Neck Peninsula, and then running east past the South Beach Road for a total distance of approximately $2,400 \mathrm{ft}$. The line was read to determine if a range in conductivities could be observed that might indicate changes in total dissolved solids in the groundwater at the water table (Figure 31). High-amplitude anomalies to the west are caused primarily by crystalline rock reinforcement used to construct a berm along the southwestern face of the peninsula. East of the $1,000 \mathrm{ft}$ marker to approximately $1,800 \mathrm{ft}$, conductivities reflect nearnormal conditions. East of $1,800 \mathrm{ft}$, conductivities rise to values similar to those observed in the stretch of beach containing the berm materials. No immediate explanation can be given for the unusual increase to the east, unless it is associated with dissolved, high-conductivity contaminants discharged into Chesapeake Bay from the area of the TBP. The cause of this anomaly should be explored further through additional conductivity mapping north of the beach.

\subsubsection{Riot Control Burning Pit Site}

The northwest corner of the RCP site, measuring 170 by $160 \mathrm{ft}$, is located about $260 \mathrm{ft}$ west of South Beach Road. A well from USGS well cluster 1 coincides with RCP grid coordinate 13E, 22S. Electrical conductivities are shown on a color map in Figure 32. The location of the well is identified on the map by the elliptical anomaly near the northwest corner. Survey profiles are $10 \mathrm{ft}$ apart and are of variable length to the south; therefore, contours in the southern third of the map are artifacts of the contouring algorithm. Causes of anomalies where contour lines are well constrained (i.e., in the northern two-thirds of the area) are not known. A prominent positive anomaly greater than $10 \mathrm{mS} / \mathrm{m}$ trends northeast-southwest through the site. Its extensions are unknown, and it may be the product of human intervention such as a former access road, buried debris or contaminants, or it may be due to a natural subsurface feature. There is no surface expression of unusual activity in the area of the positive anomaly, although an abandoned trench and push-out debris are located in the southeast quadrant in the area of low-conductivity values.

\subsubsection{Area around Well JF133}

The Well JF133 geophysical survey area is located east of South Beach Road. Well JF133 is located at the east-central end of the area surveyed. Survey lines were run from west to east, $5 \mathrm{ft}$ apart. The area was selected for surveying because it was relatively clear of debris and vegetation except for the well cluster. Conductivities are shown in a color map in Figure 33. Conductivity relief on the map due to natural causes, such as soil type and degree of saturation, is about $10 \mathrm{mS} / \mathrm{m}$. The linear negative anomaly along the southern margin of the site is caused by the decline of the water table in the proximity of an erosional escarpment along the Chesapeake Bay shoreline. Higher-amplitude positive anomalies in the northeast and northwest corners of the site may be due to waste solids and liquids. 


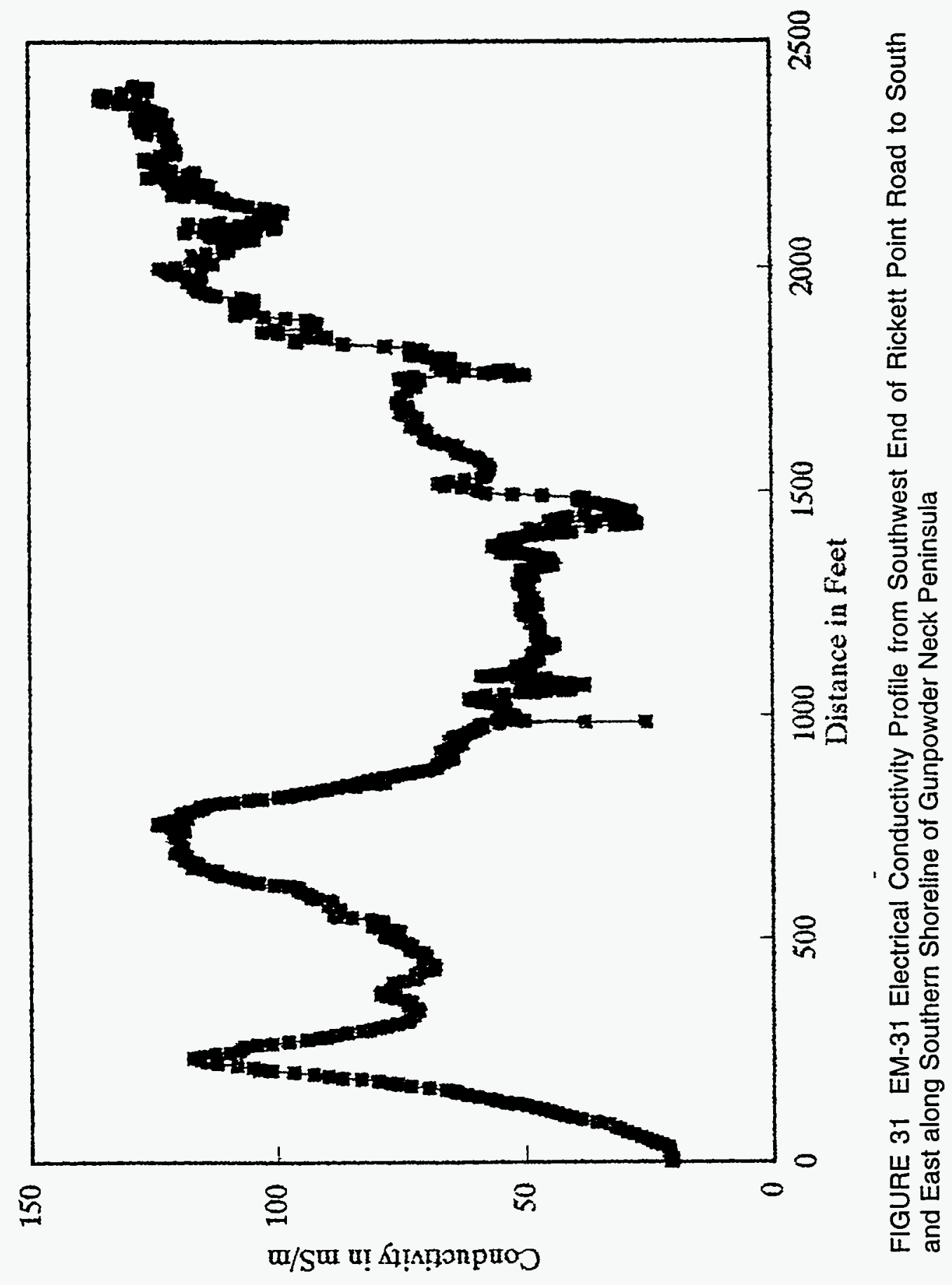




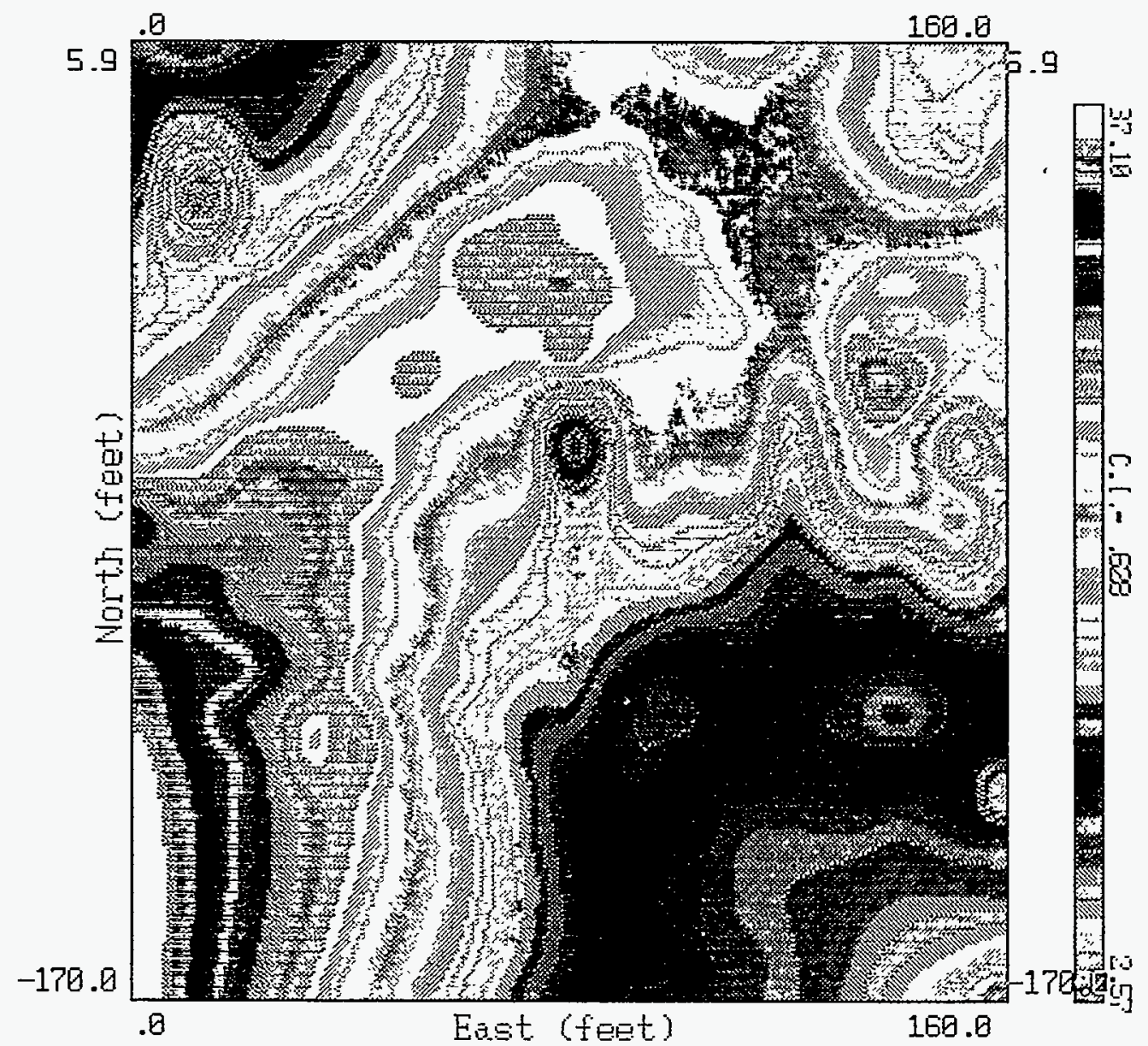

FIGURE 32 EM-31 Electrical Conductivity Color Map: RCP Site

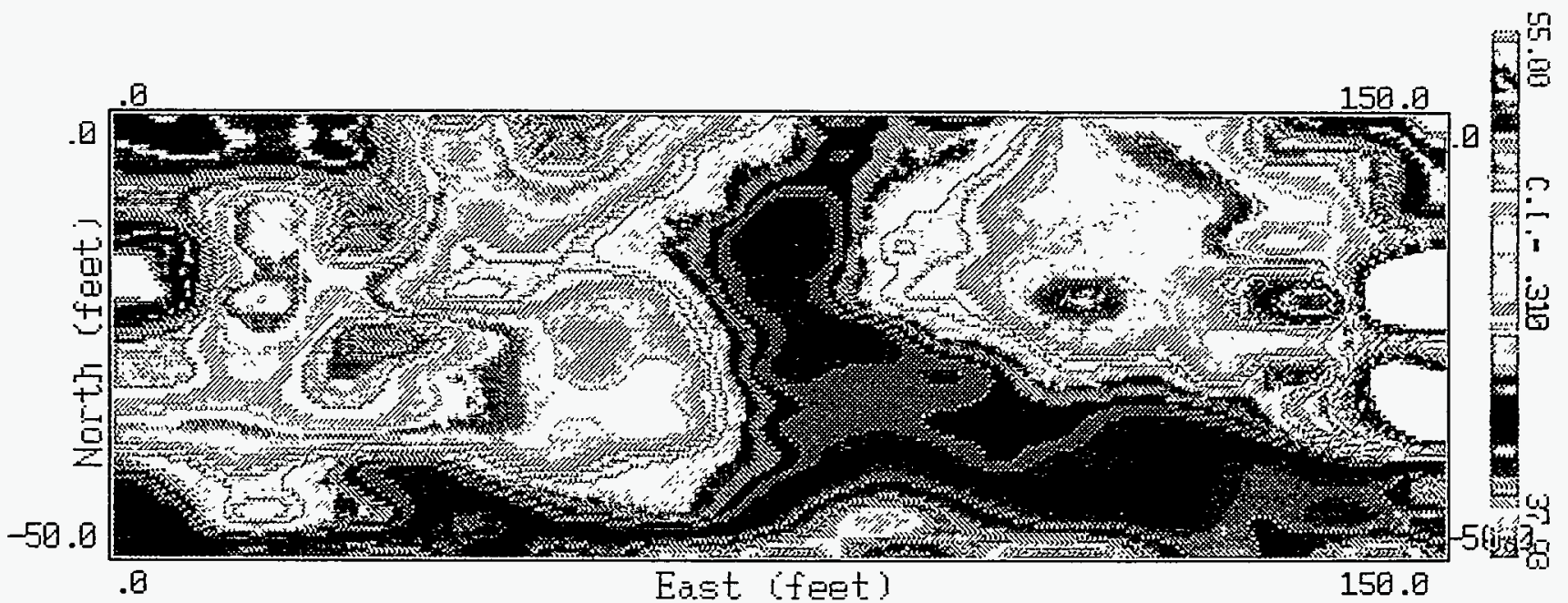

FIGURE 33 EM-31 Electrical Conductivity Color Map: JF133 Area 


\subsection{Magnetics}

An EG\&G G-822L cesium-vapor magnetometer was used to measure variations in the total magnetic field. Primary survey areas include the TBP, WPP, PBW, and RCP sites. Table 9 lists the number of stations, number of lines, and total line footage for the areas and profiles surveyed.

The data recorder for the EG\&G magnetometer captures magnetic field values at a rate of 10 readings per second in continuous-mode operation. At a constant walking speed of $3 \mathrm{ft} / \mathrm{s}$, data are therefore acquired at a rate of approximately three magnetometer readings per foot. Profiles were conducted at $10-\mathrm{ft}$ spacings at all five geophysical survey areas. The highest and lowest magnetic values were truncated in some of the color maps (based on histogram analysis) in order to highlight lower-amplitude anomalies. The contour intervals used in each map were site dependent.

\subsubsection{Toxic Burning Piis Site}

Magnetic surveys were conducted at the TBP site and also along a north-to-south profile east of the site. Total-intensity magnetic-field values at the TBP site are shown with electrical conductivities in the maps in Figure 26. In Figure 26A, magnetic values are represented as a color map overlaid by conductivity contours. In Figure 26B, conductivity values are represented as magnetic contours over a conductivity color map. (Conductivity information is discussed in the section for electrical conductivity, Section 3.5.) A second color map of magnetic anomalies with a smaller contour interval is shown in Figure 34. Grid lines show profile locations.

Magnetic values in Figure 26A and B range from approximately 34,700 to 74,000 nanoteslas (nT). Histogram analysis performed on the magnetic data indicates that $90 \%$ of the measurement points range from 51,250 to $56,500 \mathrm{nT}$. The gray rectangles on Figure 34 represent the TBP site and an area of tall weeds where no magnetic data were collected. The location of Rickett Point Road is indicated by the gray strip in the western third of Figure 34.

TABLE 9 Magnetic Survey Parameters

\begin{tabular}{lccc}
\hline & & $\begin{array}{c}\text { Total Line Footage } \\
(\mathrm{ft})\end{array}$ \\
Area & No. of Stations & No. of Lines & \\
\hline & & & 16,540 \\
TBP & 39,500 & 113 & 16,960 \\
WPP & 35,240 & 65 & 7,650 \\
PBW & 16,330 & 27 & 1,840 \\
RCP & 5,220 & 16 & \\
\hline
\end{tabular}




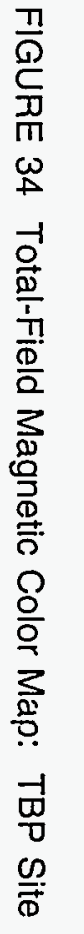

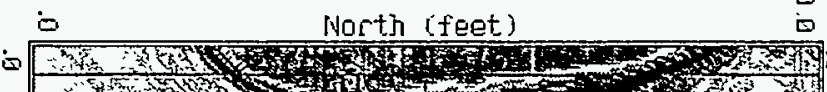

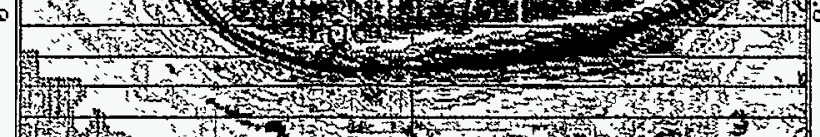

(X)

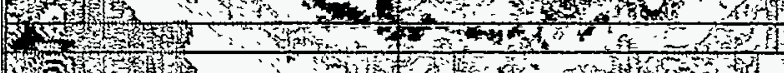

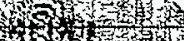

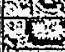
3.7. 3.

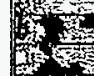

薏.
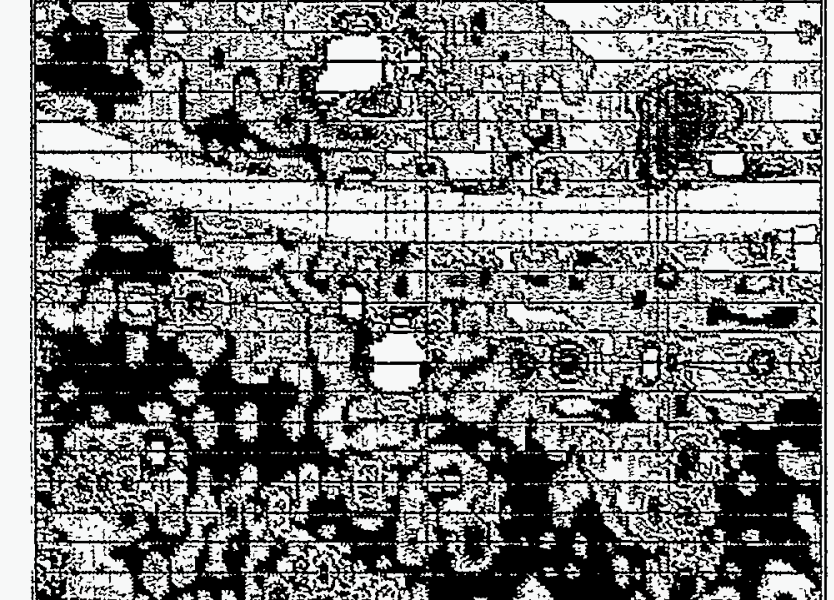

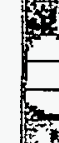

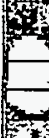
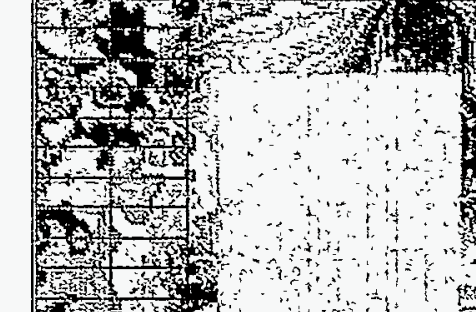

$$
\text { (1) }
$$

㲾

क

哣
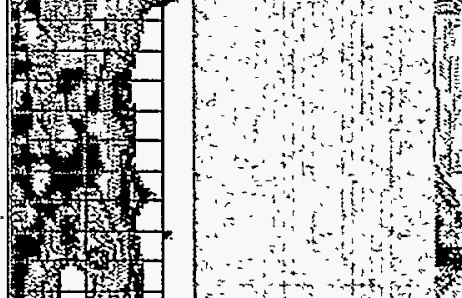
Magnetic anomalies associated with buildings and other structures include the broad magnetic minimum along the western edge of Figure 34, which is attributed to the Prototype Building; a magnetic minimum just west of Rickett Point road near the northern edge of the survey area, produced by a reinforced concrete bunker; and a 10-ft-diameter magnetic positive anomaly centered at survey coordinate $140 \mathrm{E}, 105 \mathrm{~N}$ west of Rickett Point road, caused by a metal burn container. A north-south linear trend of anomalies, starting at coordinate $210 \mathrm{E}, \mathrm{ON}$ and ending at $250 \mathrm{E}, 260 \mathrm{~N}$, is caused by metal posts, wire, and other metallic debris associated with an old fence line. The magnetic minimum at survey location $310 \mathrm{E}, \mathrm{ON}$ and the lows between $265 \mathrm{E}$ and $305 \mathrm{E}$ and between $195 \mathrm{~N}$ and $220 \mathrm{~N}$ are caused by the USGS well cluster 4 (wells JF41, JF42, and JF43).

The complex magnetic area in the northeast part of the survey area (just north of the open pits at the TBP site) is most likely due to metallic debris observed at the surface. The same applies to the anomalies just northwest of the TBP site and to the anomalies along the southern edge of the TB! site. The complex magnetic anomalies : the eastern third of the TBP site, like the conductivities in the area, are partly caused by push-out debris.

Several anomalies are observed that do not correlate with features that are visible at the surface. Two linear trends are observed, an east-west trend of magnetic anomalies along $215 \mathrm{~N}$ (extending from $305 \mathrm{E}$ to $480 \mathrm{E}$ ) and a trend extending northwest from the north-central edge of the two open pits at the TBP site $(532 \mathrm{E}, 165 \mathrm{~N})$. The linear trend along $215 \mathrm{~N}$ is co-linear with a conductivity anomaly and it is interpreted to be the magnetic signature of the liquid smoke disposal pit (located in Figure 2). The northwest trending lineament also coincides with conductivity data and may be associated with the VX burning pit. Both the liquid smoke disposal pit and the VX burning pit are buried and are not immediately identifiable by visual observation. Geophysical observations provide valuable information in identifying the precise locations and dimensions of the pits. Additional valuable information for the VX burning pit is given in the GPR coverage, Section 3.7, and in Section 4.

Several point-source anomalies are observed in the magnetic data: a minimum at $80 \mathrm{E}, 15 \mathrm{~N}$; one maximum and two minimum in the south-central part of the surveyed area centered at $275 \mathrm{E}$, $30 \mathrm{~N}$; a magnetic maximum centered at $335 \mathrm{E}, 10 \mathrm{~N}$, approximately $15 \mathrm{ft}$ in diameter; and a high/low anomaly pair centered at $545 \mathrm{E}, 25 \mathrm{~N}$. The sources of these anomalies are unknown.

\subsubsection{White Phosphorous Burning Pits Site}

Total-intensity magnetic-field values at the WPP site are shown with electrical conductivities in Figure 27. Magnetic values are represented as contours over a conductivity color map in Figure 27A and as a separate color map overlain by profile locations in Figure $27 \mathrm{~B}$. Conductivity information is discussed in the section for electrical conductivity, Section 3.5. For

safety reasons, no magnetic data were collected in the open pits. No-data areas are indicated by grey blocks in the figures. 
Magnetic values in Figure 27A and B range from 42,685 to 64,600 nT. A contour interval of $10 \mathrm{nT}$ was used for the color map in Figure 27B. Rickett Point Road is observed in the anomalies of both magnetic and conductivity data as a north-south band of anomalies along the east side of Figure 27 at survey coordinate 315E. Several other anomalies can also be directly attributed to surface features. The two most prominent negative anomalies, at grid coordinates $62 \mathrm{E}, 68 \mathrm{~N}$ and $292 \mathrm{E}, 156 \mathrm{~N}$ (southwest and southeast corners, respectively), are caused by small, metallic buildings within the geophysical survey area. The three localized negative anomalies spaced about $10 \mathrm{ft}$ apart at grid coordinate 236E, 168N are caused by USGS well cluster 9 (wells JF91, JF92, and JF93). The east-west lineament in the middle of the survey area, extending from Rickett Point Road (east edge of Figure 27) to the trenches in the west central area, is caused at least in part by an access road and associated sign posts and gates. Surficial metallic debris was observed, particularly along Rickett Point Road in the central and southern part of the survey area. This explains some of the localized magnetic anomalies on the eastern side of the survey area.

A linear, east-west trend that extends from $0 \mathrm{E}$ to $210 \mathrm{E}$ along, $120 \mathrm{~N}$ consists of numerous high-intensity, localized anomalies. The sources of the anomaies are apparently shallow; perhaps caused by a former road bed or metallic debris. The lineament is not observed in either the conductivity or the GPR data.

An east-west line of localized anomalies is located just north of, and also east of, the WPP site and north of the east-west service road (between $310 \mathrm{~N}$ and $340 \mathrm{~N}$ ). These anomalies may be indicative of former waste burial activities associated with the WPP site. They are relatively weak anomalies and are generally not associated with any immediately visible metallic debris at the surface. They might be indicative of an additional buried trench. However, they do not appear to be associated with any linear expression in the conductivity data.

\subsubsection{West Side of Prototype Building Site}

Total-intensity magnetic-field values at the $\mathrm{PBW}$ site are shown with electrical conductivities in the maps in Figure 28. In Figure 28A magnetic values are represented as a color map overlaid by conductivity contours. In Figure 28B conductivity values are represented by magnetic contours over a conductivity color map (the reverse of Figure 28A). (Conductivity information is discussed Section 3.5.)

The PBW site has a magnetic field ranging from 44,215 to $60,745 \mathrm{nT}$. A contour interval of $55 \mathrm{nT}$ was used for the color map in Figure 28A. The magnetic data in Figure 28A and B are dominated by broad high and low magnetic anomalies in the eastern third of the survey area, which are caused by the adjacent PBW. The east-west trend of anomalies in the west-central part of the survey area is caused by a reinforced cement walkway. The three magnetic anomalies that form a north-south trend in the south-central part of the survey area, centered at $130 \mathrm{E}, 60 \mathrm{~N}$, coincide with USGS well cluster 3 (wells JF31, JF32, and JF33). 
In the northern half of the area, three isolated, localized anomalies of relatively high intensity are observed at $10 \mathrm{E}, 245 \mathrm{~N} ; 100 \mathrm{E}, 245 \mathrm{~N}$; and $150 \mathrm{E}, 215 \mathrm{~N}$. They are not associated with any known surface objects but have relatively shallow features.

When compared to data at the TBP (Figure 26) and the WPP (Figure 27), the magnetic field at the PBW (Figure 28) indicates that little buried metal debris is present. This conclusion is based on a relatively uniform magnetic background at the PBW.

\subsubsection{Riot Control Burning Pit Site}

An area east of the RCP site was surveyed in order to gain insight on shallow hydrogeological characteristics and on the range of total-intensity magnetic-field values to be expected under conditions less disturbed than the TBP and WPP sites. The area surveyed by the magnetic method was slightly smaller than the area surveyed by electrical conductivity. However, both surveys used the same grid-coordinate system. A magnetic map of the RCP site with a contour interval of $18.2 \mathrm{nT}$ is shown in Figure 35. The magnetic field values range from 49,888 to $56,289 \mathrm{nT}$. A well from USGS cluster 1 appears as a minimum in the northwest corner of Figure 38. The large minimum centered at grid coordinate 150E, 57S (at the east-central edge of the magnetic survey area) is caused by a large metallic object, clearly visible at the surface. A northeast-southwest trend of magnetic anomalies is observed in the southwest to central portion of Figure 35. This trend coincides with a conductive trend in the EM-31 data (Figure 32). The source of the anomalies is not known.

\subsection{Ground-Penetrating Radar Investigations}

Ground-penetrating radar surveying was accomplished with a model SIR-3 GPR unit equipped with a model 38 video display unit connected to a transceiver with a $300-\mathrm{ft}$-long cable. Data were recorded on a digital audio tape through the model 38 system. The digital audio tape unit permits playback and downloading to a personal computer. The control unit/video display was located in the transport vehicle. An IBM-compatible processing computer was located in a field office so the GPR profiles could be downloaded, the data-tape quality checked, and preliminary data processing performed. Radan III computer software written by GSSI was used for processing the GPR profile data.

The primary objective of the GPR was to help detect and locate unknown burial trenches or pits at three separate areas within J-Field: the TBP and WPP sites, and an area west of the PBW site.

Before the production lines were run for the survey at J-Field, replicate runs were made over the same line to determine which of the two transceivers, the $100-$ or $300-\mathrm{MHz}$ monostatic 


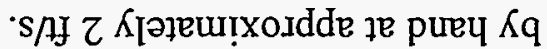

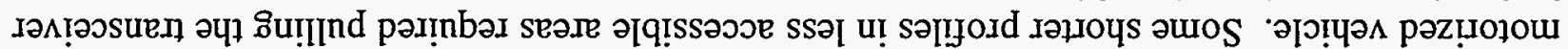

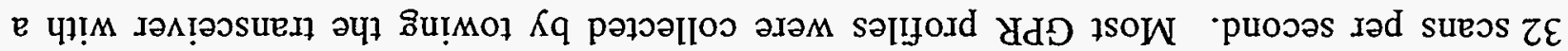

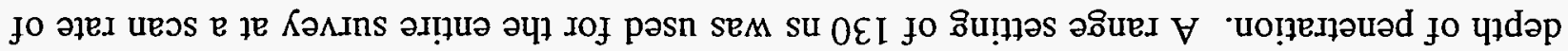

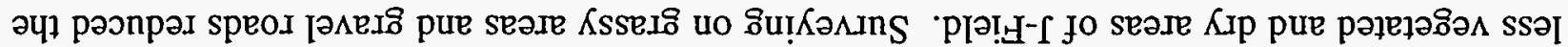

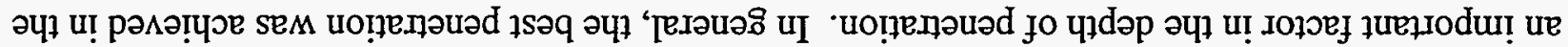

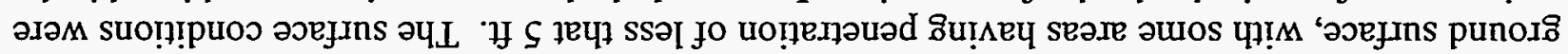

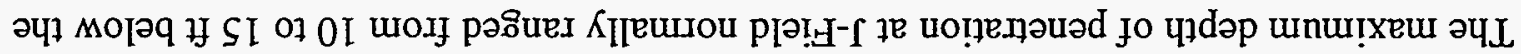

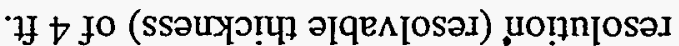

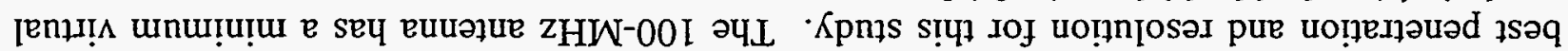

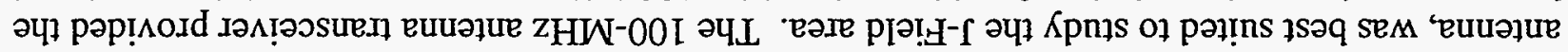

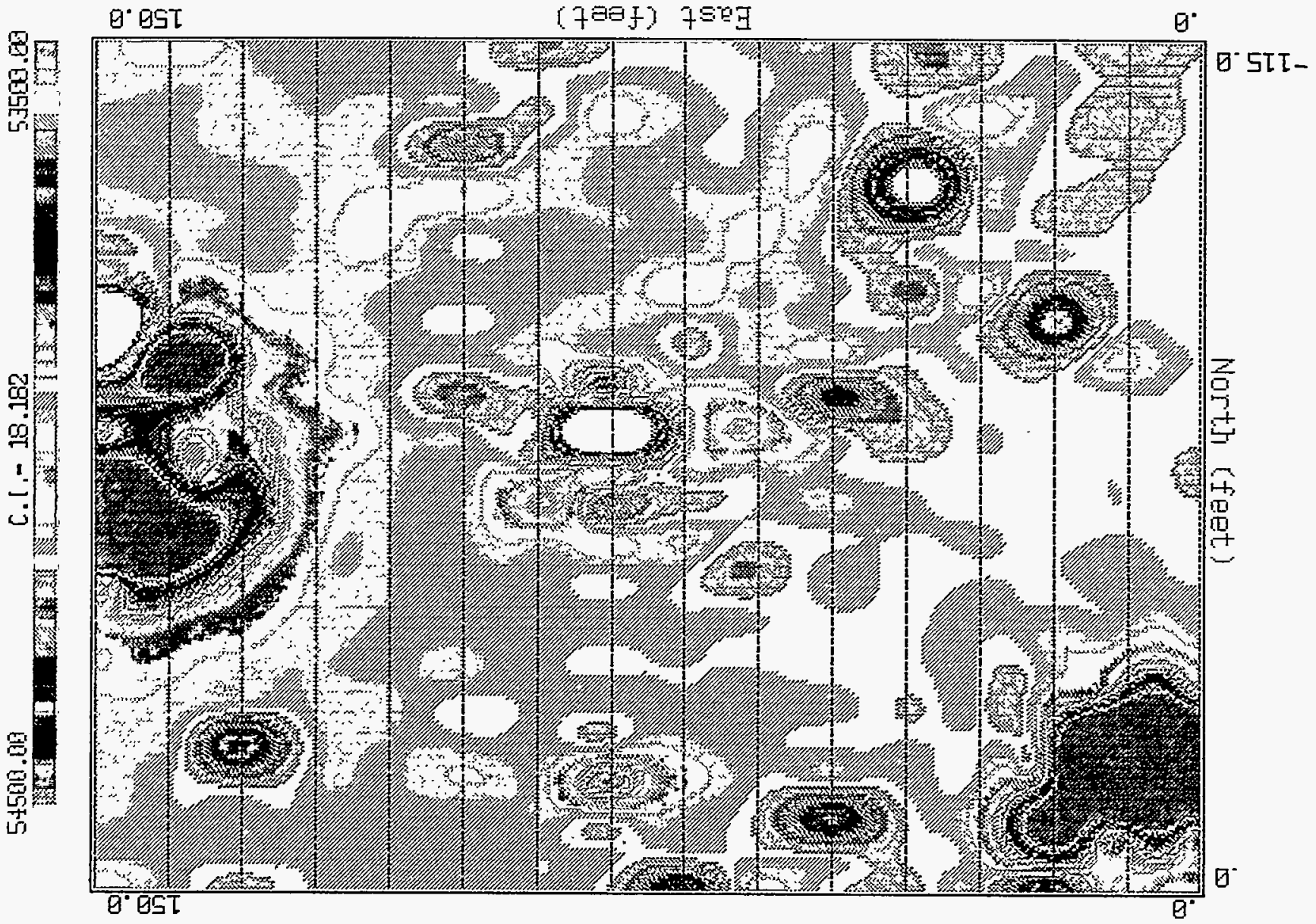




\subsubsection{Toxic Burning Pits Site}

Ground-penetrating radar measurements were collected at 50-ft intervals along roughly east-west and south-north profiles within the staked survey area at the TBP site. Some north-south profiles north of the open trenches were extended outside of the survey area. A total of over $8,625 \mathrm{ft}$ was surveyed along 50 profiles. Figure 36 shows the locations of the GPR profile 1 through profile 37 within the survey area. Table 10 lists all the profiles collected at the site (profiles 1 through 50).

Two GPR profiles at the TBP site, profiles 13 and 28, shown in Figure 37, reveal anomalies that could be interpreted as burial pits or trenches. Each profile shows features that could be associated with the VX burn pit. Anomalies in profile 13, a north-south line, are observed at $520 \mathrm{E}, 175 \mathrm{~N}$ and $520 \mathrm{E}, 205 \mathrm{~N}$. A relatively strong reflector is observed at $535 \mathrm{E}, 200 \mathrm{~N}$ in profile 28. GPR profile 9, shown in Figure 38, has a more subtle anomaly centered at $265 \mathrm{~N}$. The cause $c$ tise anomaly is unknown.

A small area located northeast of the open trenches, including profiles 38 through 50 (see Table 10), was also added to the GPR survey. This area, centered roughly at the survey coordinate $800 \mathrm{E}$ and $190 \mathrm{~N}$, lacked vegetation at the time of the survey, and some metal debris was exposed at the surface. The GPR profiles revealed some scattered debris buried no deeper than $1 \mathrm{ft}$. The depth of penetration was less than $5 \mathrm{ft}$ below the ground surface; however, buried debris was not detected below $1 \mathrm{ft}$. The reduced depth of penetration may be caused by the nearsurface shallow debris and by the very clayey surface soils.

\subsubsection{White Phosphorous Burning Pits Site}

Ground-penetrating radar measurements were collected at 50-ft intervals along orthogonal profiles, numbered from 1 to 25 , within the staked survey area at the WPP site. More than 7,395 linear $\mathrm{ft}$ were surveyed (see Figure 39). Table 11 lists all the profiles collected at the site. No new trenches or burial pits were identified in the GPR data collected at WPP.

\subsubsection{West Side of Prototype Building Site}

Ground-penetrating radar measurements were collected at 50-ft intervals along orthogonal profiles within the staked survey area at the PBW site. More than 3,550 linear feet was surveyed along 13 profiles. Figure 40 shows the locations of the GPR profiles within the staked survey area. Table 12 lists all the profiles collected at the site, including some profiles outside the staked area. No trenches or burial pits were identified in the GPR data collected at PBW. 


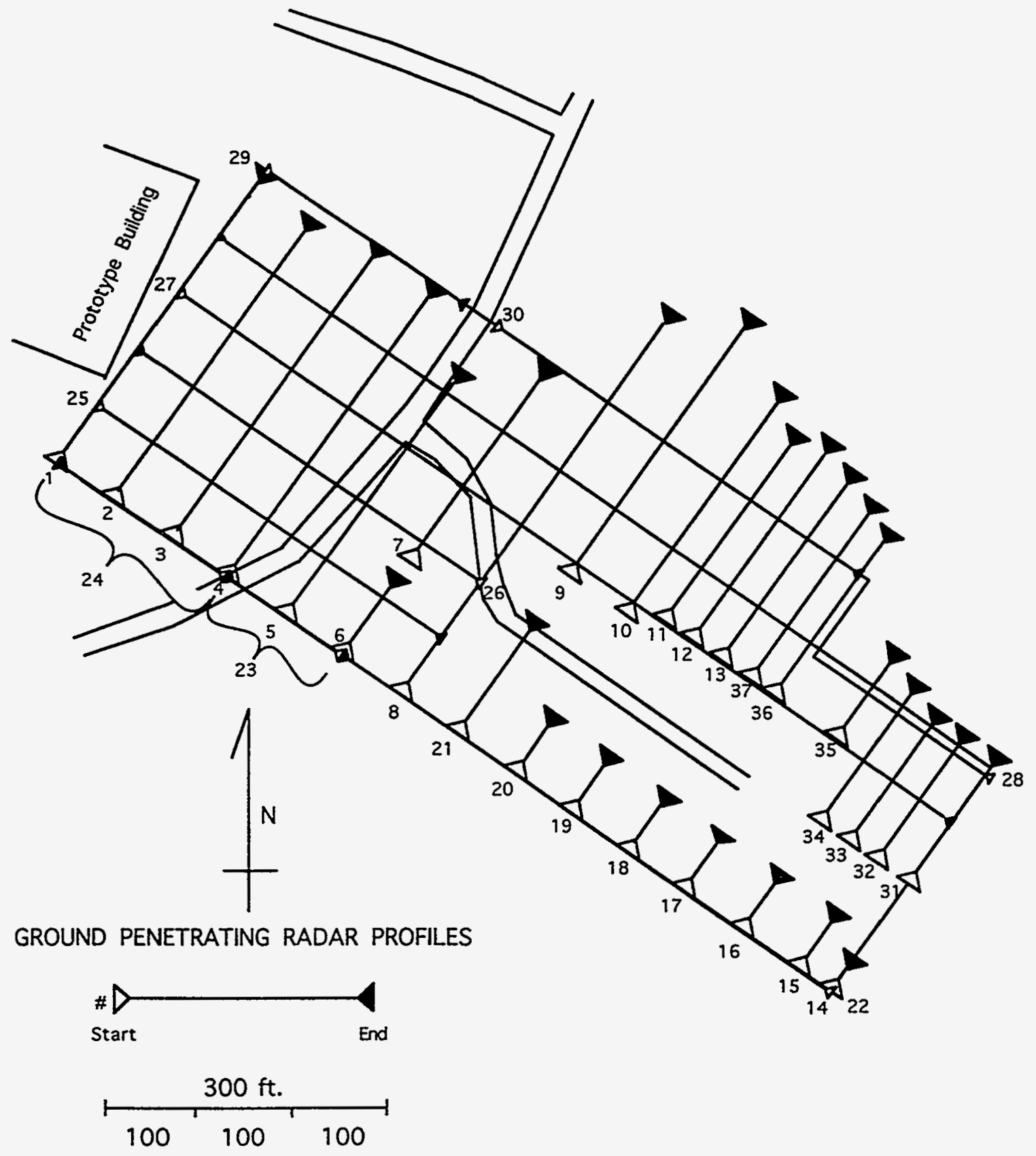

FIGURE 36 Locations of GPR Profiles: TBP Site 
TABLE 10 Ground-Penetrating Radar Profiles: TBP Site

\begin{tabular}{|c|c|c|c|c|}
\hline \multirow[b]{2}{*}{$\begin{array}{c}\text { Profile } \\
\text { No. }\end{array}$} & \multicolumn{2}{|c|}{ Start Coordinates } & \multicolumn{2}{|c|}{ End Coordinates } \\
\hline & East & North & East & North \\
\hline $\begin{array}{l}1 \\
2 \\
3 \\
4 \\
5 \\
6 \\
7 \\
8 \\
9 \\
10 \\
11 \\
12 \\
13 \\
14 \\
15 \\
16 \\
17 \\
18 \\
19 \\
20 \\
21 \\
22 \\
23 \\
24 \\
25 \\
26 \\
27 \\
28 \\
29 \\
30 \\
30 \\
31 \\
32 \\
33 \\
34 \\
35 \\
36 \\
37 \\
37 \\
38 \\
39 \\
40 \\
41 \\
49 \\
43 \\
43 \\
49 \\
45 \\
40 \\
46 \\
47 \\
48 \\
49 \\
50\end{array}$ & $\begin{array}{l}000 \\
050 \\
100 \\
150 \\
200 \\
250 \\
250 \\
300 \\
350 \\
400 \\
450 \\
500 \\
520 \\
670 \\
650 \\
600 \\
550 \\
500 \\
450 \\
400 \\
350 \\
670 \\
250 \\
150 \\
000 \\
000 \\
000 \\
670 \\
000 \\
200 \\
670 \\
650 \\
625 \\
600 \\
575 \\
475 \\
425 \\
785 \\
790 \\
795 \\
800 \\
805 \\
810 \\
810 \\
810 \\
810 \\
810 \\
810 \\
810 \\
815\end{array}$ & $\begin{array}{l}000 \\
000 \\
000 \\
000 \\
000 \\
000 \\
090 \\
000 \\
140 \\
140 \\
150 \\
150 \\
150 \\
000 \\
000 \\
000 \\
000 \\
000 \\
000 \\
000 \\
000 \\
000 \\
000 \\
000 \\
050 \\
100 \\
150 \\
200 \\
260 \\
260 \\
095 \\
095 \\
095 \\
095 \\
150 \\
150 \\
150 \\
210 \\
210 \\
210 \\
210 \\
210 \\
210 \\
210 \\
200 \\
190 \\
180 \\
170 \\
160 \\
150\end{array}$ & $\begin{array}{l}000 \\
050 \\
100 \\
150 \\
200 \\
250 \\
250 \\
300 \\
350 \\
400 \\
450 \\
500 \\
520 \\
670 \\
650 \\
600 \\
550 \\
500 \\
450 \\
400 \\
350 \\
250 \\
150 \\
000 \\
300 \\
300 \\
670 \\
000 \\
175 \\
520 \\
670 \\
650 \\
625 \\
600 \\
575 \\
475 \\
425 \\
785 \\
790 \\
795 \\
800 \\
805 \\
810 \\
785 \\
785 \\
785 \\
785 \\
765 \\
785 \\
785\end{array}$ & $\begin{array}{l}260 \\
250 \\
260 \\
260 \\
220 \\
070 \\
260 \\
340 \\
370 \\
340 \\
330 \\
310 \\
300 \\
030 \\
050 \\
050 \\
050 \\
050 \\
050 \\
050 \\
100 \\
000 \\
000 \\
000 \\
050 \\
100 \\
150 \\
200 \\
260 \\
260 \\
210 \\
210 \\
210 \\
220 \\
230 \\
320 \\
320 \\
145 \\
145 \\
145 \\
145 \\
145 \\
145 \\
210 \\
200 \\
190 \\
180 \\
170 \\
160 \\
150\end{array}$ \\
\hline
\end{tabular}



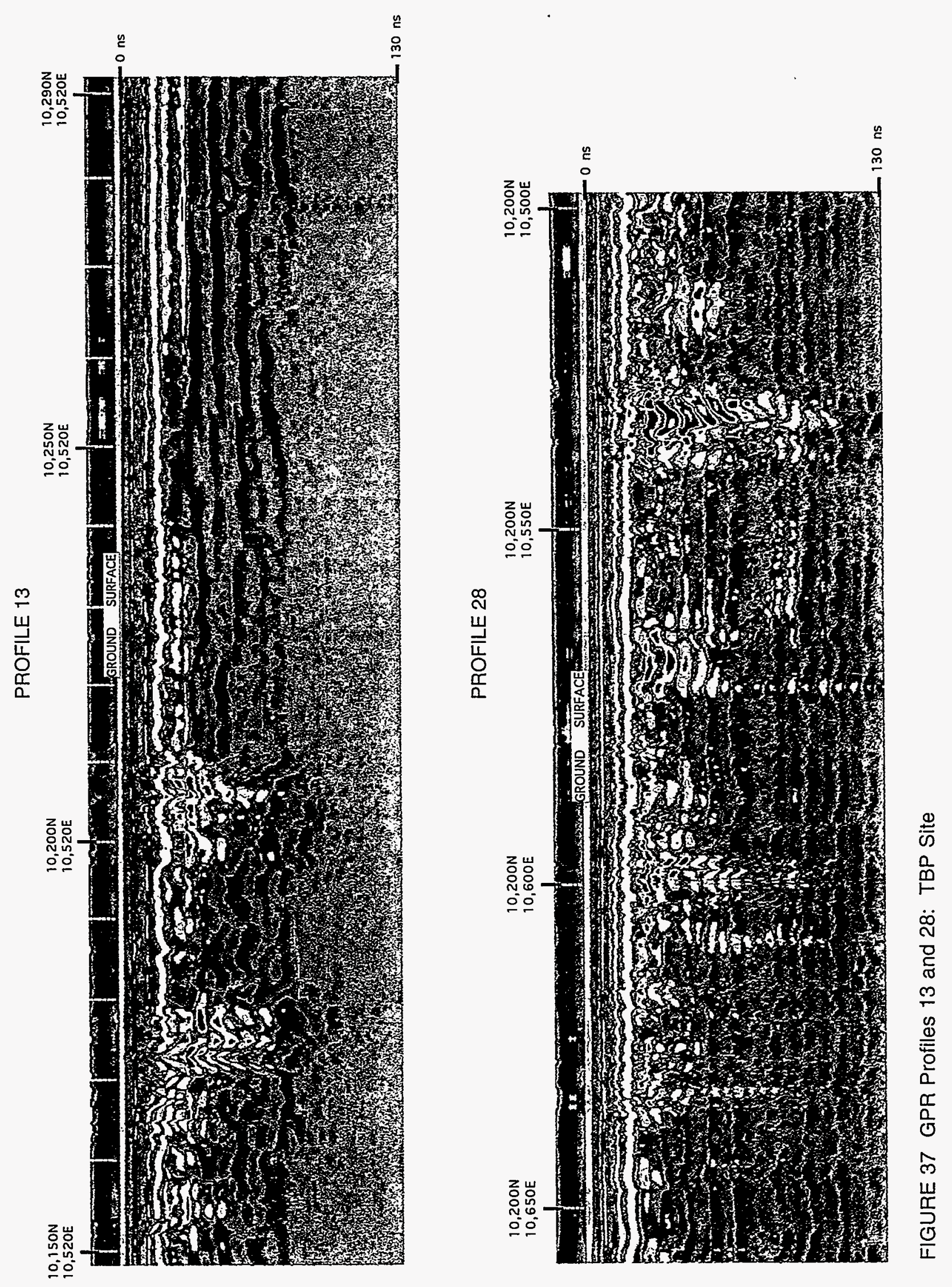


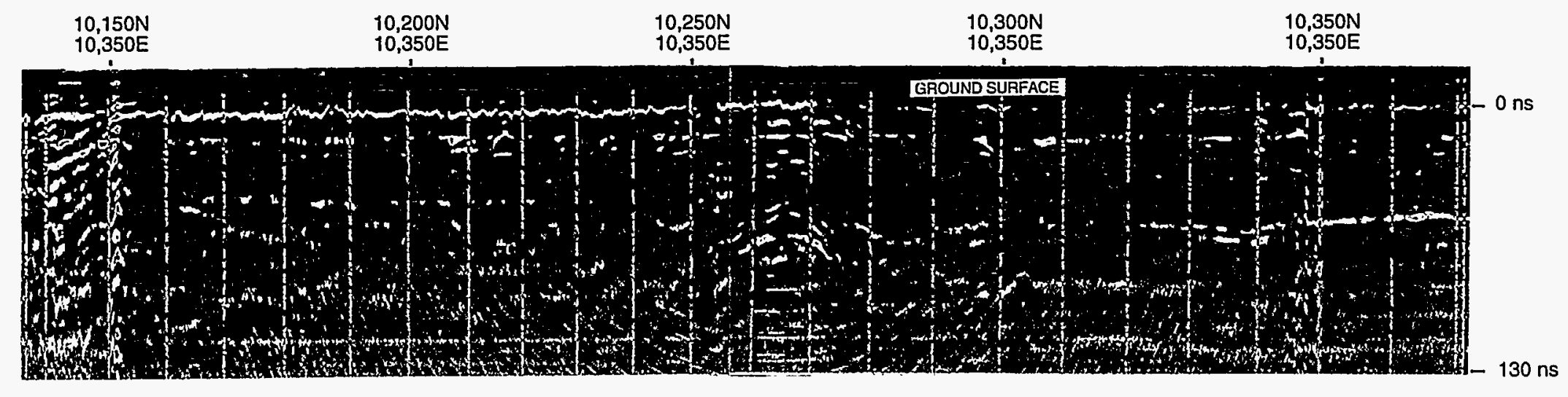

FIGURE 38 GPR Profile 9: TBP Site 


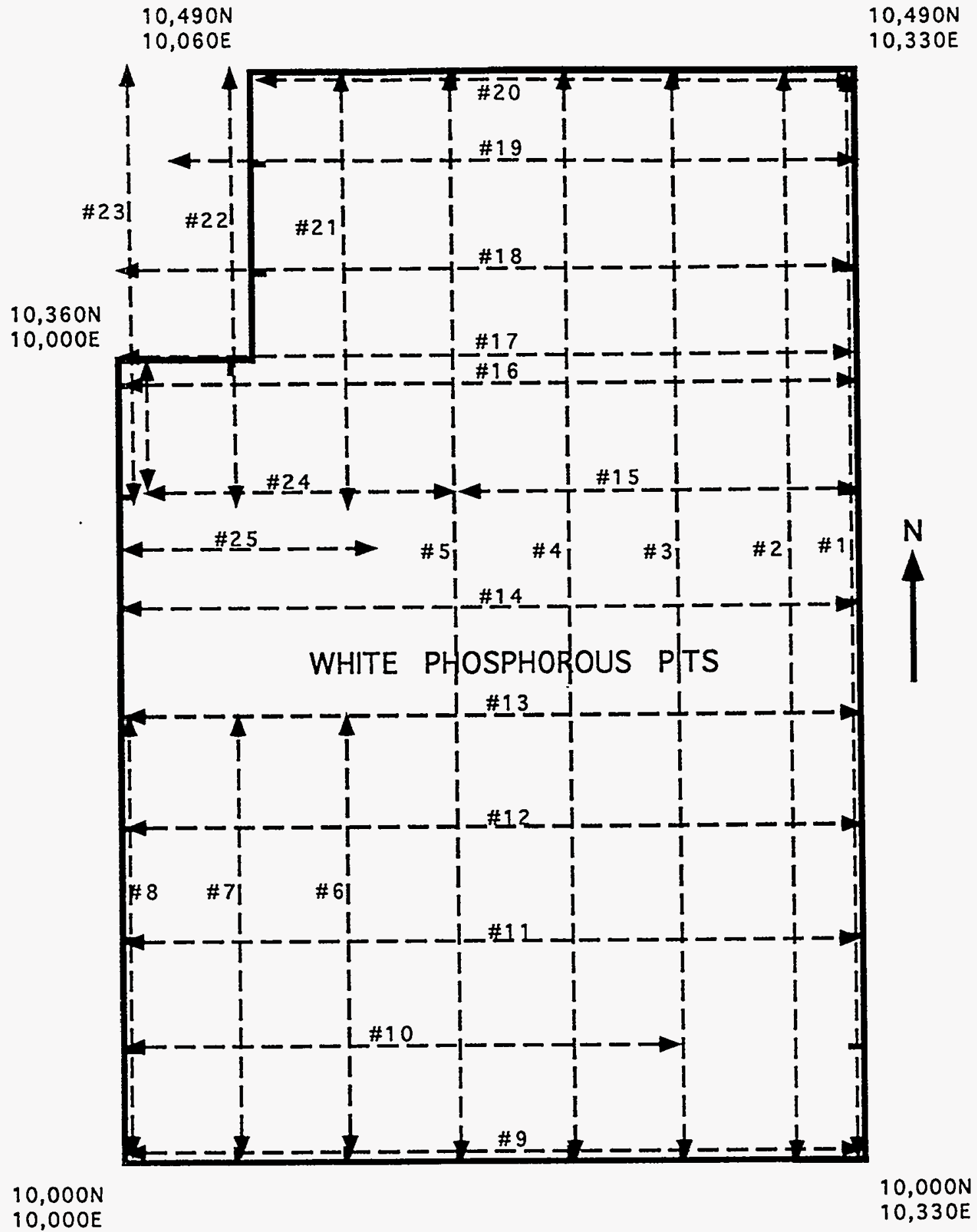

FIGURE 39 Location of GPR Profiles: WPP Site 
TABLE 11 Ground-Penetrating Radar Profiles: WWP Site

\begin{tabular}{|c|c|c|c|c|}
\hline \multirow{2}{*}{$\begin{array}{c}\text { Profile } \\
\text { No. }\end{array}$} & \multicolumn{2}{|c|}{ Start Coordinates } & \multicolumn{2}{|c|}{ End Coordinates } \\
\hline & East & North & East & North \\
\hline 1 & 330 & 000 & 330 & 490 \\
\hline 2 & 300 & 490 & 300 & 000 \\
\hline 3 & 250 & 000 & 250 & 490 \\
\hline 4 & 200 & 490 & 200 & 000 \\
\hline 5 & 150 & 000 & 150 & 490 \\
\hline 6 & 100 & 200 & 100 & 000 \\
\hline 7 & 050 & 200 & 050 & 000 \\
\hline 8 & 000 & 200 & 000 & 000 \\
\hline 9 & 000 & 000 & 330 & 000 \\
\hline 10 & 000 & 050 & 250 & 050 \\
\hline 11 & 330 & 100 & 000 & 100 \\
\hline 12 & 000 & 150 & 330 & 150 \\
\hline 13 & 330 & 200 & 000 & 200 \\
\hline 14 & 330 & 250 & 000 & 250 \\
\hline 15 & 330 & 300 & 150 & 300 \\
\hline 16 & 000 & 350 & 330 & 350 \\
\hline 17 & 000 & 360 & 330 & 360 \\
\hline 18 & 330 & 400 & 000 & 400 \\
\hline 19 & 020 & 450 & 330 & 450 \\
\hline 20 & 330 & 490 & 060 & 490 \\
\hline 21 & 100 & 300 & 100 & 490 \\
\hline 22 & 050 & 300 & 050 & 490 \\
\hline 23 & 010 & 300 & 010 & 360 \\
\hline 24 & 010 & 300 & 150 & 300 \\
\hline 25 & 000 & 325 & 115 & 325 \\
\hline
\end{tabular}




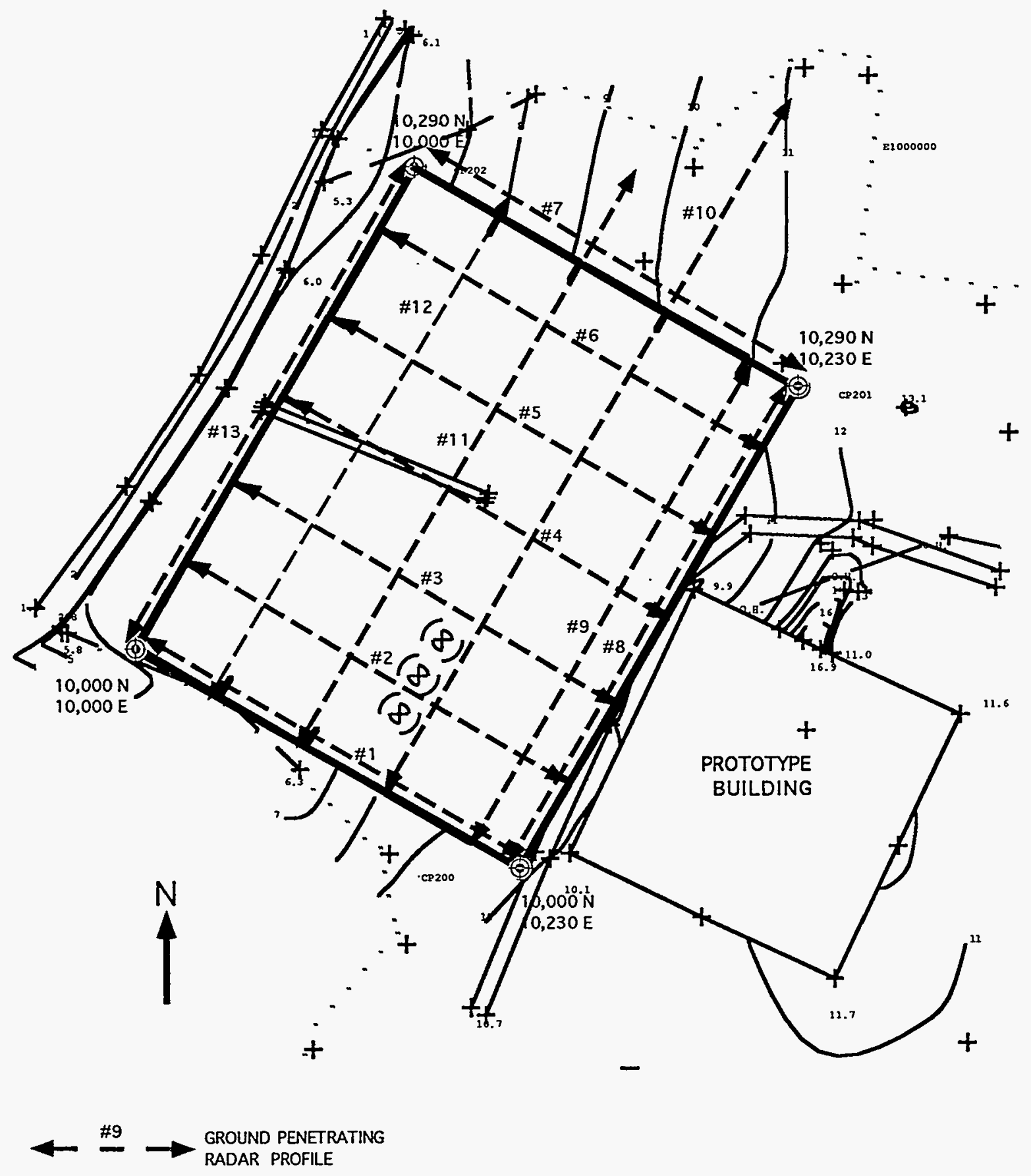

FIGURE 40 Location of GPR Profiles: PBW Site 
TABLE 12 Ground-Penetrating Radar Profiles: PBW Site

\begin{tabular}{|c|c|c|c|c|}
\hline \multirow{2}{*}{$\begin{array}{c}\text { Profile } \\
\text { No. }\end{array}$} & \multicolumn{2}{|c|}{ Start Coordinates } & \multicolumn{2}{|c|}{ End Coordinates } \\
\hline & East & North & East & North \\
\hline 1 & 000 & 000 & 230 & 000 \\
\hline 2 & 230 & 050 & 000 & 050 \\
\hline 3 & 230 & 100 & 000 & 100 \\
\hline 4 & 230 & 150 & 000 & 150 \\
\hline 5 & 230 & 200 & 000 & 200 \\
\hline 6 & 230 & 250 & 000 & 250 \\
\hline 7 & 230 & 300 & 000 & 300 \\
\hline 8 & 230 & 000 & 230 & 290 \\
\hline 9 & 200 & 290 & 200 & 000 \\
\hline 10 & 150 & 000 & 150 & 420 \\
\hline 11 & 100 & 350 & 100 & 000 \\
\hline 12 & 050 & 000 & 050 & 300 \\
\hline 13 & 000 & 290 & 000 & 000 \\
\hline
\end{tabular}




\section{Discussion}

Geophysical data presented in this report fall into two categories, which include:

1. Data that assist in the characterization of the natural hydrogeologic framework of the J-Field area, and

2. Data that assist in the characterization of the disturbed environment that are diagnostic of intrusive solids and liquids.

Seismic and electrical resistivity data generally fit in the first category by providing information on the depth, thickness, and character of the leaky confining unit at the base of the surficial aquifer. Ground-penetrating radar, magnetic, and electrical data fit in the second category by providing diagnostic signatures of buried trenches, hazardous materials facilities, and other near-surface disturbances. The magnetic response is sensitive both to natural variations, such as the relative clay content vs. sand content below the surface, and ferrous metallic debris. Electrical conductivity values are sensitive to both natural variations and man-made disturbances. Electrical conductivity is sensitive to variations in soil chemistry, depth to water-saturated sediments, electrolyte content in the groundwater, and nonconductive contaminants. All of the geophysical methods deployed at J-Field, with the possible exception of seismic studies, fit to some extent in both the natural hydrogeologic framework and the disturbed environment categories.

Near-surface geophysical data in this report become most useful when analyzed along with historical documentation of site activity. Site information based on aerial photographs of J-Field from 1965, during a period of peak military activity, provide critical site-specific documentation for the remedial investigation and feasibility study. Former, but now obscure, trenches, access points, facilities, materials, substances, and other features may be identified or suspected from examining the photographic documentation. Shallow geophysical data can then provide a means of confirming and precisely locating boundaries of such observed features.

\subsection{Geophysical Characterization of the Leaky Confining Unit}

Seismic reflection profiles (presented in Subsection 3.3.2) show both the top and bottom of the Talbot Formation Unit B, also called the leaky confining unit, at the TBP site. Figure 41 shows color maps of Unit B interpreted from seismic reflection data. Figures $41 \mathrm{~A}$ and B are color contour maps illustrating the configuration of the top and bottom of Unit B. The map coordinates are the same used for the TBP geophysical survey site shown in Figure 8. The maps were generated using seismic reflector depths every $25 \mathrm{ft}$ along each profile, then converting depths to mean elevation above sea level, calculating a grid for the map area using a minimumcurvature gridding technique, and graphically portraying gridded elevations with colors using a contour interval of $2.5 \mathrm{ft}$ for each color. Color elevation values are only reliable in the vicinity of seismic lines, which are indicated by black dots. 

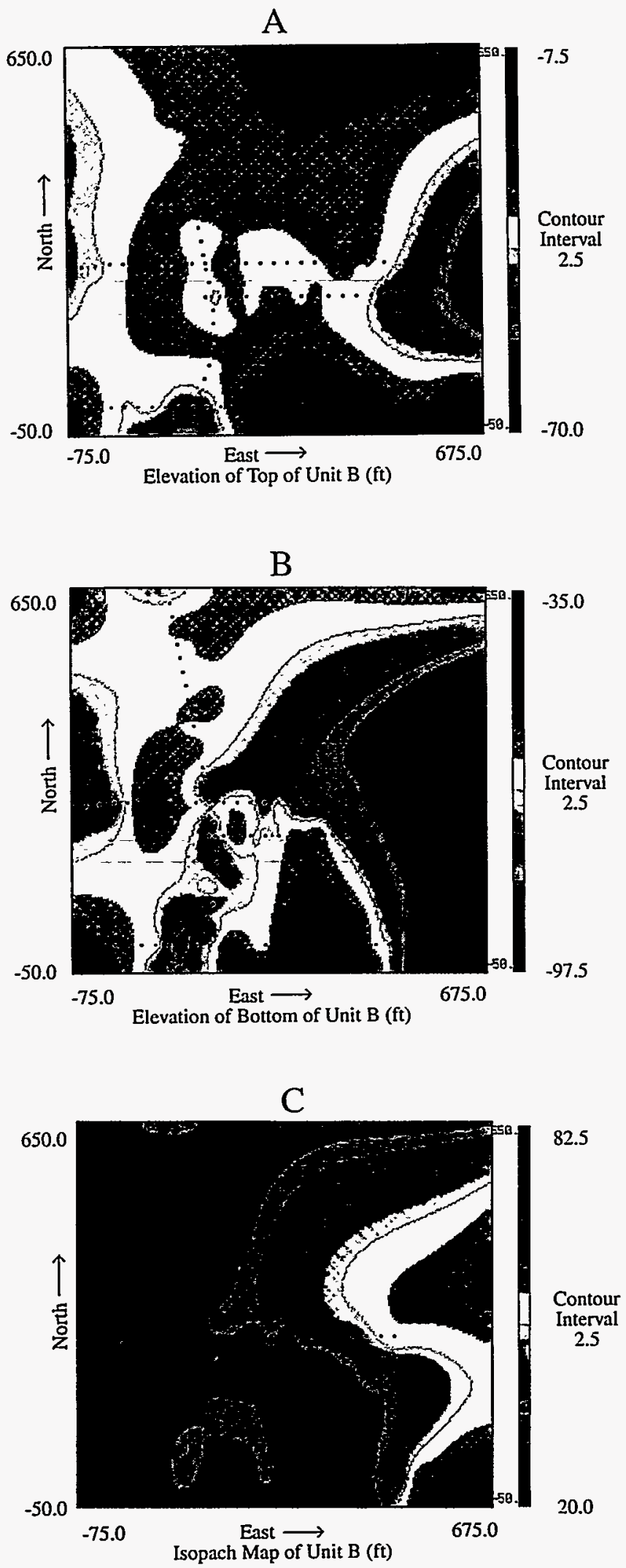

FIGURE 41 Color Maps of Unit B Interpreted from Seismic Reflection Data. A: Elevation of Top of Unit B; B: Elevation of Bottom of Unit B; C: Isopach Map of Unit B. 
Figure $41 \mathrm{~A}$ indicates that elevations for the top of Unit B range from 15 to $45 \mathrm{ft}$ below MSL. Elevations for the bottom of Unit B, shown in Figure 41B, range from 40 to $95 \mathrm{ft}$. Depths calculated for both surfaces suffer from near-surface velocity variations that could not be effectively corrected. The actual ranges of elevations are probably less than observed in either Figure $41 \mathrm{~A}$ or $\mathrm{B}$.

While the actual depth ranges of the surfaces may be slightly exaggerated, the general topography of each is believed to be valid. Also, the thickness of Unit B, shown in the isopach map (Figure $41 \mathrm{C}$ ), is less affected by errors caused by near-surface velocity variations than the elevation calculations because errors in depth due to uncorrected velocity change are mitigated in the process of subtracting one surface from the other. The top of Unit B (Figure 41A) is shallowest along an axis extending north from $450 \mathrm{E}, \mathrm{ON}$ in the southern part of the map, or roughly in the central part of the map. The bottom of Unit B (Figure 41B) deepens significantly to the east. The thickness of Unit B shown in Figure $41 \mathrm{C}$ ranges from only 25 to $35 \mathrm{ft}$ in most of the western half of the map to up to $80 \mathrm{ft}$ in the eastern half.

Electrical and velocity measurements acquired on Pleistocene strata at J-Field provide significant hydrogeologic constraint on groundwater flow models. Seismic reflection data do not reveal any discontinuities in Unit B. Abnormally low seismic compressional-wave velocities calculated from seismic refraction data, having velocities less than the velocity of sound in water, suggest that the upper part of Unit B may consist of gassy sediments.

\subsection{Ground Disturbances at the Toxic Burning Pits Site}

Two east-west trenches are currently exposed at the TBP site. Historically, the length of the trenches has changed, and other trenches have become filled in. Two pre-existing trenches, the VX burning pit and the liquid smoke disposal pit, no longer have obvious surface expressions. Both pits, however, are observed in a 1965 aerial photograph and are shown in Figure 42. Locations of all features in Figure 42 are primarily based on the aerial photograph.

Electromagnetic data (Figure 26), total-intensity magnetic data (Figures 26 and 34), and ground-penetrating radar data (Figure 37) all show anomalies at the TBP site near coordinate $535 \mathrm{E}, 200 \mathrm{~N}$. The anomalies in each data set are subtle, but careful inspection associates these anomalies with the VX burning pit observed in the aerial photograph, represented in Figure 42. Magnetic data, in particular, show a linear feature extending northwest from the north side of the toxic burn pits at $540 \mathrm{E}, 150 \mathrm{~N}$.

Electromagnetic and total-intensity magnetic data also show an east-west linear feature at about $215 \mathrm{~N}$ between the VX burning pit on the east and Rickett Point Road on the west. These anomalies are associated with the liquid smoke disposal pit shown in Figure 42. 


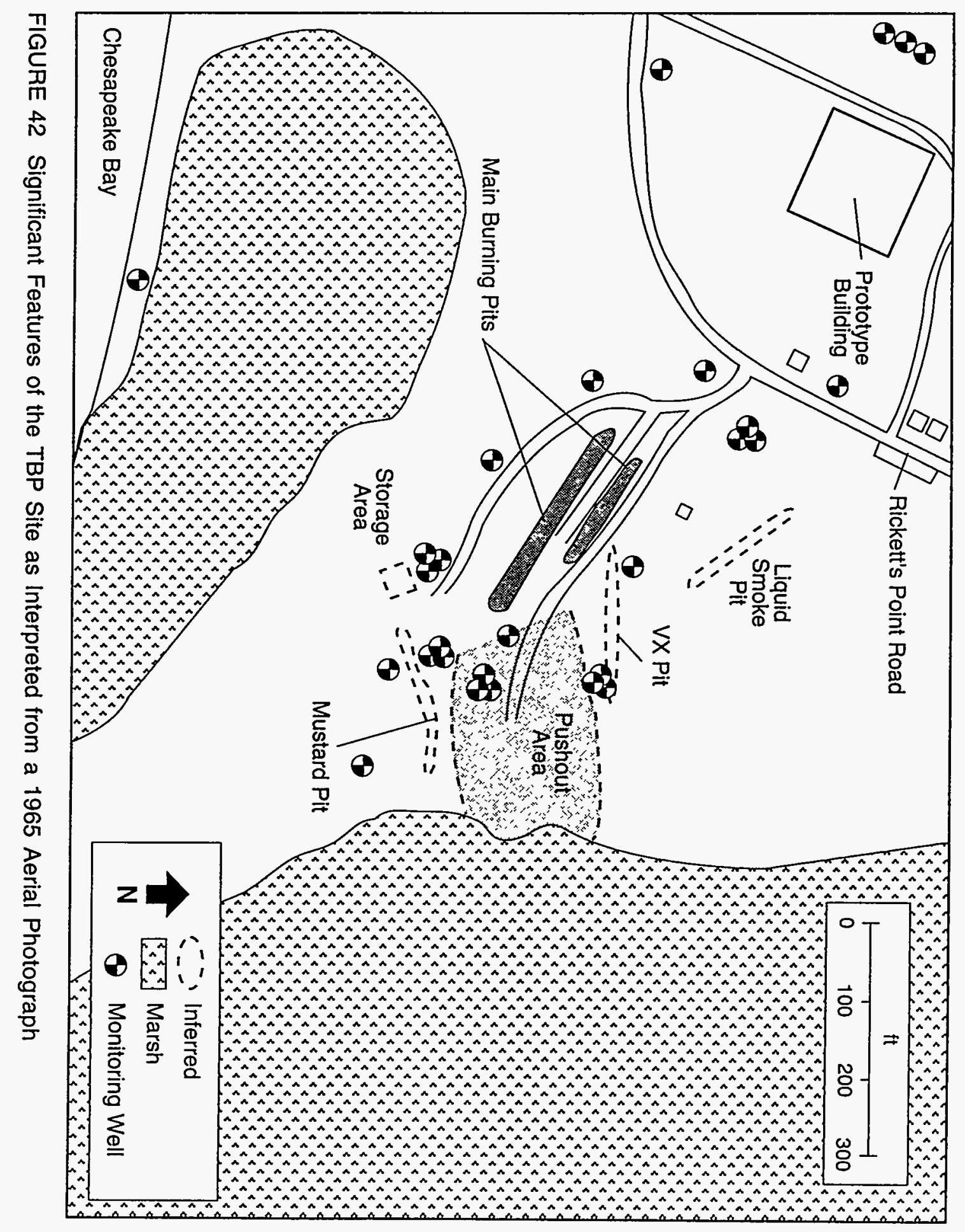




\subsection{Ground Disturbances at the White Phosphorous Burning Pits Site}

Two east-west trenches are currently exposed at the WPP site. The lengths of these two trenches have changed over time. Total-intensity magnetic data (Figure 27) suggest an east-west trending anomaly south of the southern half of the map, at about $110 \mathrm{~N}$. The 1965 photograph of the WPP site (not included in this report) does not reveal any corresponding unusual feature, nor do electromagnetic data (Figure 27) or radar profiles (Figure 39) reveal any strong anomalies that would likely be associated with a trench. The magnetic anomalies might be associated with either metallic debris or gravel used in constructing access roads.

Magnetic data also reveal strong anomalies between $200 \mathrm{~N}$ and $360 \mathrm{~N}$ north and west of the existing trenches. These anomalies are likely associated with push-out material and/or other materials associated with activities at the two visible trenches.

\subsection{Ground Disturbances West of the Prototype Building Site}

A 1965 aerial photograph of the PBW site (not included in this report) shows that the site was cleared of all vegetation. No trenching activities are evident in the photograph. The east-west linear feature observed in the photograph corresponds to a cement slab in the middle of the PBW site that still exists. Other than the concrete slab, no other striking anomalies are observed in electromagnetic, total-intensity magnetic, or GPR data.

\subsection{Ground Disturbances at the Riot Control Burning Pit Site}

The RCP geophysical survey area is slightly east of the actual riot control pit. Neither electomagnetic (Figure 32) or total-intensity magnetic (Figure 35) anomalies are directly associated with the riot control pit, whose extent and location are known from aerial photographs. Most likely, all anomalies observed in Figures 32 and 35 are associated with randomly scattered surfical metallic debris. 


\section{Conclusions}

Seismic reflection profiling was used to define the upper and lower surfaces of the leaky confining layer (Unit B). The depths of reflectors corresponding to Unit B of the Talbot Formation were constrained by gamma log data from nearby boreholes. Continuous correlation between boreholes is made possible with the seismic reflection profiles. Electrical resistivity surveys provided additional information on the approximate positions of the upper and lower contacts of Unit B.

Limits to two former trenches at the TBP site have been defined through the use of magnetic, conductivity, and ground-penetrating radar surveys. The features are identified as the former liquid smoke disposal pit and former VX burning pit. Present trench boundaries in the TBP and WPP sites are defined by anomalous push-out areas, which contain high-density concentrations of ferromagnetic and conductive debris. Anomalies are concentrated around trench margins and down-slope from known trenches. Preliminary GPR data do not detect trench boundaries.

Conductive plumes identified during USGS reconnaissance surveys, were not observed by any geophysical surveys conducted by ANL. The anomalies reported in the USGS survey may

not be associated with plumes, but rather may be produced by push-out debris and increased saturation at lower elevations. 


\section{References}

Bennett, R.R., and R.R. Meyer, 1952, Geology and Groundwater Resources of the Baltimore Area, Maryland Department of Geology, Mines, and Water Resources, Bulletin 4.

Benson, R.N., 1992, Map of Exposed and Buried Early Mesozoic Rift Basins/Synrift Rocks of the U.S. Middle Atlantic Continental Margin, Delaware Geological Survey, Misc. Map Series 5.

Cleaves, E.T., 1968, Piedmont and Coastal Plain Geology Along the Susquehanna Aqueduct, Baltimore to Aberdeen, Maryland, Maryland Geological Survey, R.I. 8.

Dingman, R.J., H.F. Ferguson, and R.O. Martin, 1956; The Water Resources of Baltimore and Harford Counties, Maryland Department of Geology, Mines and Water Resources, Bulletin 17.

Hughes, W.B., 1991, "Application of Marine-Seismic Profiling to a Ground-Water Contamination Study, Aberdeen Proving Ground, Maryland," Groundwater Monitoring Review 11(1):97-102.

Hughes, W.B., 1993, Hydrogeology and Soil Gas at Aberdeen Proving Ground, Maryland, U.S.A. Geological Survey, Water Resource Investigation 92-4087.

Kehrin, R.T., et al., 1988, The Surficial Sediments of the Chesapeake Bay, Maryland - Physical Characteristics and Sediment Budget, Maryland Geological Survey, report no. 48.

.McGinnis, L.D., et al., 1991, "Velocity Depression and Degasification Subsidence in Louisiana Wetlands," in Coastal Depositional Systems in the Gulf of Mexico - Quaternary Framework and Environmental Issues, Gulf Coast Section Society of Economic Paleontologists and Mineralogists Foundation, Twelfth Annual Research Conference, pp. 128-134.

McGinnis, L.D., et al., 1992, "Coastal Resistivity and Seismic Signatures of the Holocene in an Epoch of Transgressive Seas - Mississippi Delta," EOS Transactions, American Geophysical Union (45).

McGinnis, L.D., et al., 1992, "Significance of Geophysical and Engineering Properties of the Holocene in an Abandoned Mississippi Delta Plain," Geological Society of America, SE Section, Abstracts with Programs.

McGinnis, L.D., et al., 1994, Environmental Geophysics at Beach Point, Aberdeen Proving Grounds, Maryland, ANL/ESD-23, Argonne National Laboratory, Argonne, Ill. 
Meisler, H., 1986, "Northern Atlantic Coastal Plain Regional Aquifer-System Study," Regional Aquifer-System Analysis Program of the U.S. Geological Survey Summary of Projects, U.S.A. Geological Survey Circular 1002, R.J. Sun, editor, pp. 168-194.

Oliveros, J.P., and D.A. Vroblesky, 1989, Hydrogeology of the Canal Creek Area, Aberdeen Proving Ground, Maryland, U.S. Geological Surveys Water-Resources Investigations, report 89-4021.

Otton, E.G., and R.J. Mandle, 1984, Hydrogeology of the upper Chesapeake Bay Area, Maryland, with Emphasis on Aquifers in the Potomac Group, Maryland Geological Survey, Report of Investigations, no. 39.

Owens, J.P., 1969, "Coastal Plain Rocks of Harford County," The Geology of Harford County, Maryland, Maryland Geological Survey, pp. 77-103.

Southwick, D.L., J.P. Owens, and J. Edwards, Jr., 1969, The Geology of Harford County, Maryland, Maryland Geological Survey.

Thompson, M.D., et al., 1993, "Gas- Rich Sediment in Coastal Wetland Louisiana," Proceedings of the Symposium on the Application of Geophysics to Engineering and Environmental Problems, SAGEEP 93, vol. 2, San Diego, Calif., pp. 463-476.

Thompson, M.D., et al., 1993, "Acoustic Signature of Holocene and Pleistocene Sediment in Coastal Louisiana," EOS Transactions, American Geophysical Union (46). 